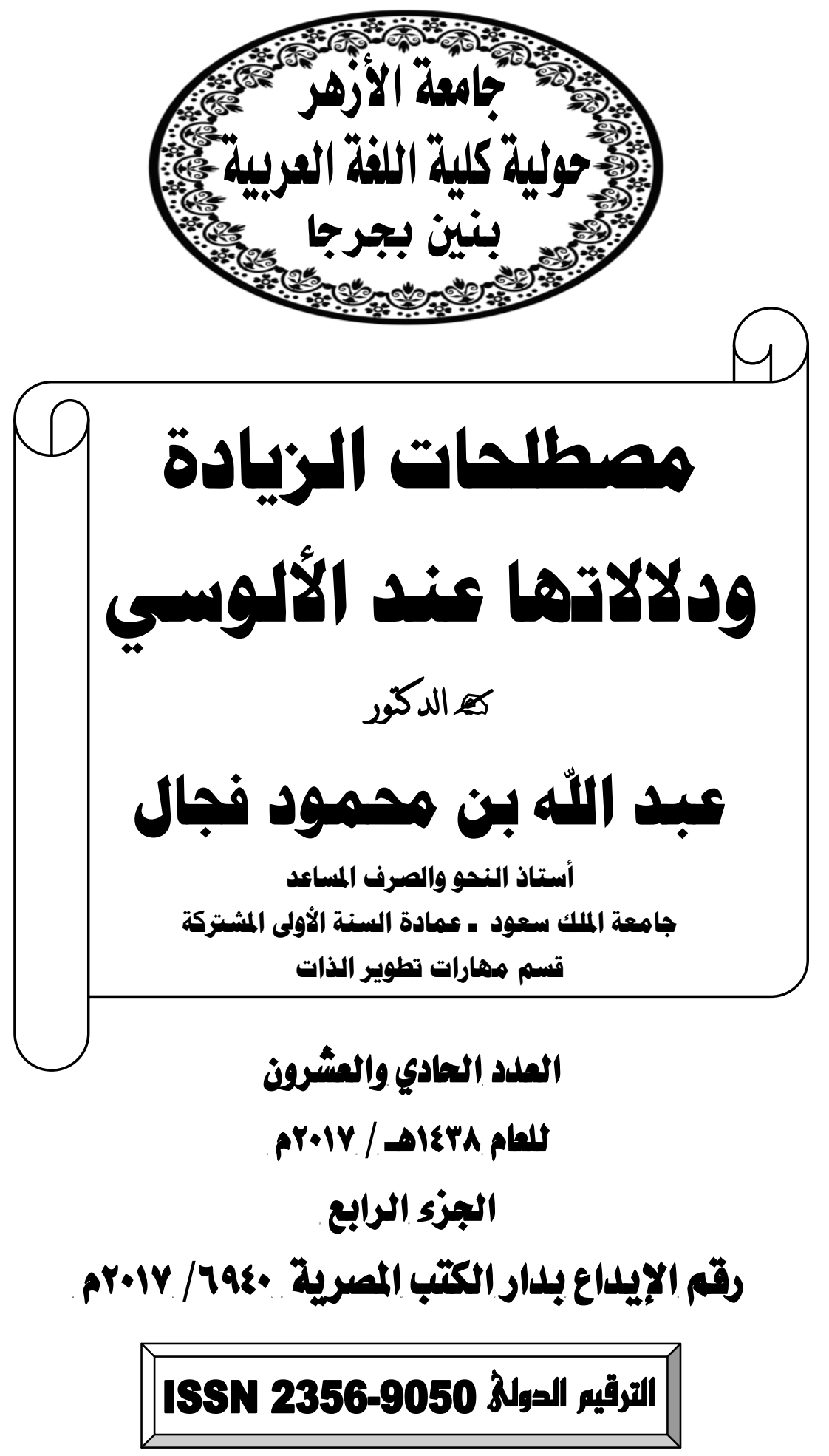




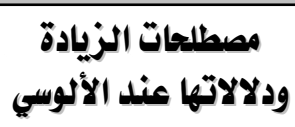

\section{* ș}

\section{هصطات الزبيادة ودلالاتها عند الألهوسي}

unil|

شُخِلَ علماء العربية بتنـزيه القرآن الكريم عن بعض المصطلحاث التي قـ تخل بفصاحته، كالزيادة حيث إن كلام الله -عزَّ وجل - لا يعتريه نقص أو زيــادة، وتقنتوا بوضع المصطلحات البديلة لذلك، فمنهم من تركهــا علـى أصــــها فـي التسمية، ومنهم من يسميها "التوكيد"، ومنهم من يسميها "الصلة"، ومـنهم مـن يسميها "المقحم"، ومنهم من يسميها "الحشو" ومنهم من يسميها "اللغو"، وأضاف الألمسي في هذا الميدان مصطلح "سيف خطيب"؛ ليكون له باع كغيره من النحــاة

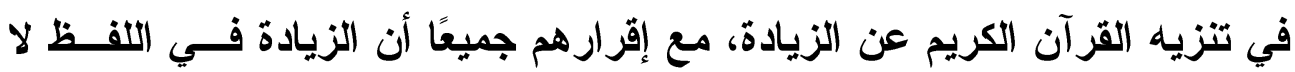
المعنى.

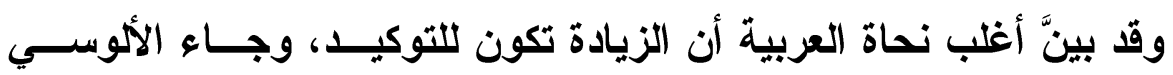
بدلالات للزيادة غيز التوكيد، وقد ناقش هذا البحث مصطلحات الألوسي في التعبيز عن الزيادة، مع هذه الدلالات الجديدة. وتنوعت المصادر التي عدث إلبها، وما بين كتب النحو والصرف قـديمها وحديثها، والمعاجم اللغوية، وكتب التفسير، وكتب إعراب القرآن. واعتمدث على المنهج الوصفي الإحصائيّ في جمع مادة البحث وعرضها ومناقثتها، وختمث البحث بخاتمة تضمنت أهم التتائج التي وصلث إليها في هـــا البحث، وقائمة للمصادر والمراجع التي عدث إليها في بحثي هذا. الكالمات الانتشاحية : الزيادة، الصلة، المقحم، سيف خطيب، التوكيد، الدلالة.

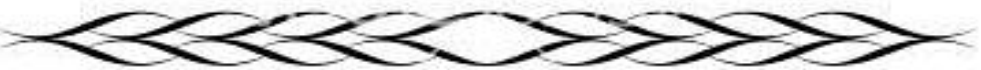




\section{الترقيم الدولخ}

ISSN 2356-9050
Q
حولية كلية اللفة العربية بجرجا

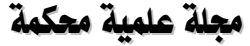

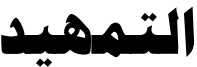

ليست الزيادة في العربية لغوًا لا معنى لها، وإنما هي مــع جمالهـــا فـي الأسلوب تكسب العبارة فضل توكيد فيما يقول البلاغيون، ولعل ابــن عبـاس رضي الله عنهما - أول من لحظ الزيادة في القرآن، فقسر بها، وأومأ إليها وهو

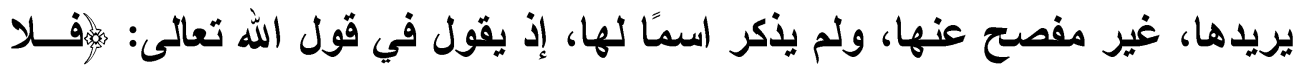

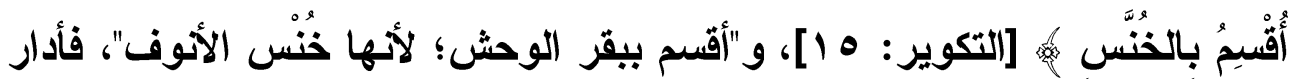
معنى الآية على ثبوت القسم لا نفيه، مع تقدم "لا" عليه (1).

ولو تتبعنا آراء علماء العربية والتفسير في حديثهم عن حروف الزيــادة في القرآن الكريم لوجدناهم مختلفين بين مثبتٍ لها ونافٍ، حيث يقول الزركثــي: "والأكثرون ينكرون إطلاق هذه العبارة في كتاب الله ويسمونهـ "التأكيد" ومنهم من يسميه بـ "الصلة" ومنهم من يسميه "المقحم"، قال ابن جني: كل حرف زيد فــي كلام العرب فهو قائم مقام إعادة الجملة مرة أخرى" (ץ).

فقد أوضح الزركشي أن مجموعة من العلماء ينكرون وجود الزيادة فـي القرآن الكريم لأنه ليس في القرآن حرف زائد، وإن كل حرف لها معنى متجدد.

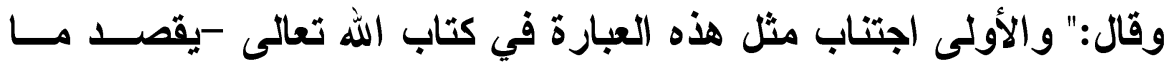

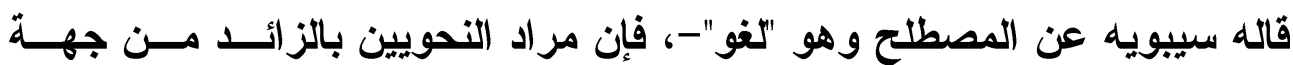
الإعراب لا من جهة المعنى" (r).

(1) انظر : بحث "هل في القرآن الكريم من أحرف الزيادة"، علي النجدي ناصف.

$$
\begin{aligned}
& \text { (r) البرهان، الزركثي، T// V . }
\end{aligned}
$$

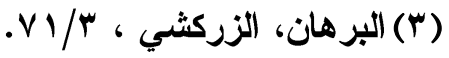

\section{0}




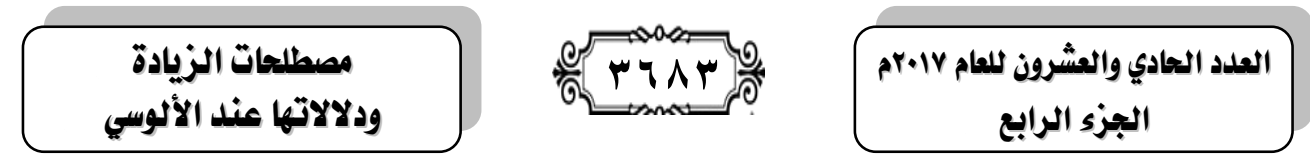

وأضاف قائكا:" وقد اختلف في وقوع الزائد في القرآن، فمنهم من أنكــره

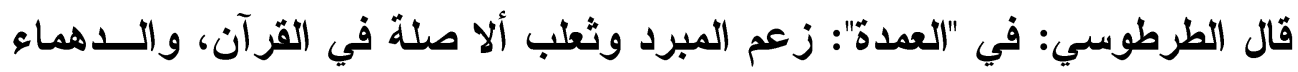

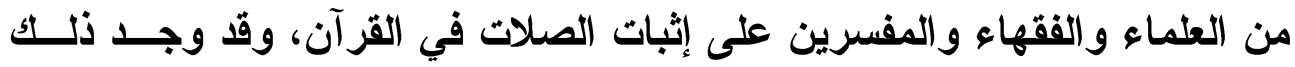
على وجه لا يسعنا إنكاره فذكر كثيرًا.

وقال ابن الخباز (1): وعند ابن السراج أنه ليس في كلام العرب زائد لأنه

تكلم بغير فائدة، وما جاء منه حمله على التوكيد. ومنهم من جوزه وجعل وجوده

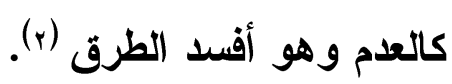

بذلك يختصر لنا الزركثي موقف العلماء من الزائد في القرآن الكريم، ولا ريب أن القرآن جاء بلغة العرب، فالقرآن عربي، وعلى أسلوب العرب يفهر. ولعل من لم يقل بالزيادة في كتاب الله - عزَّ وجل - يريد أن يهرب مـن تسميتها بالز ائد إجلاًاً واحترامًا لكلام الله من نسبة الز ائد له. وورد للزيادة مصطلحات كثيرة في كلام النحسـة، فــنهم مـن يســميها

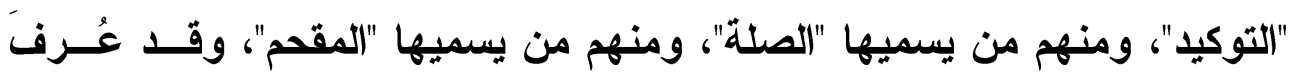

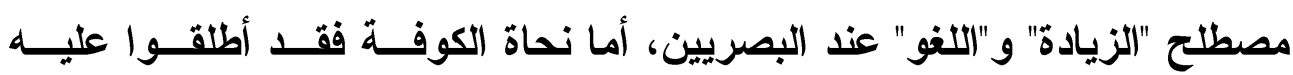
"الصلة" و"(الحشو (r).

وقد عبَّر عنه الخليل وسييويه بـــ "اللغو" في "الكتاب" حيث قال :"وســألتُ

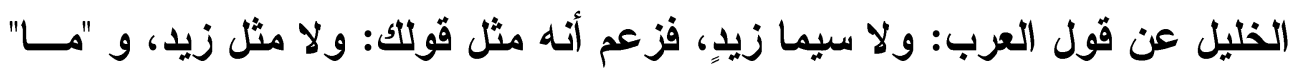

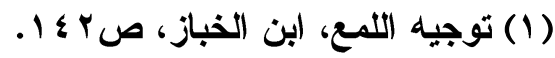

$$
\text { (Y) البرهان، الزركثي، VY/T - V }
$$

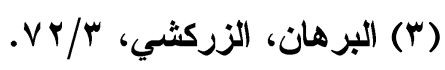




\section{الترقيم الدولخ}

ISSN 2356-9050
एक्ष
حولية كلية اللفة العربية بجرجا مجلة علمية محكمة

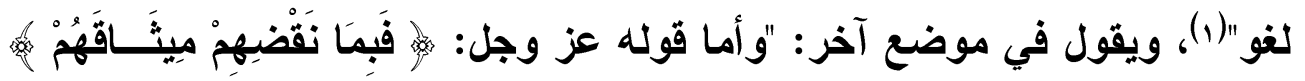

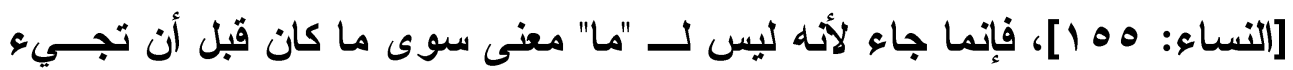

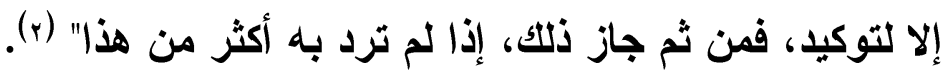
وعبَّر المبردّد بالزيادة مكان اللغو (r)، وكذلك الرمَّاني(ء).

وأراد الكوفيون أن يكون لهم في الزيـــادة مصــطلحان كمــا للبصــريين مصطلحان، فقالو ا "صلة وحثو"(ه).

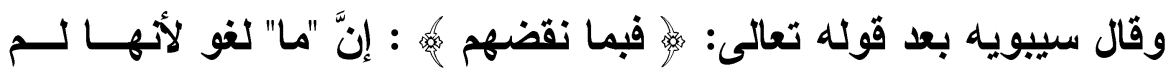
تحدث شيئًا لم يكن قبل أن تجيء من العمل وهي توكيد للكلام (؟). فجوهر عمل حروف الزيادة قائم على توثيق الجملة، ويرى ابن جنــي أن كل حرف زيد في كلام العرب فهو قائم مقام إعادة الجملة مرة أخرى (v).

فالحرف الزائد ليس لله إعراب، ولا يعني أنهله ليس لــهـه معنــى، فالزيـــادة مصطلح نحويّ وليس من الكلام أن يكون المصطلح مطابقًا للالاية المقامية، فهم

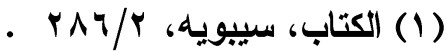

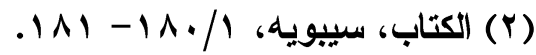

$$
\begin{aligned}
& \text { (T) المقتضب، المبرد، }
\end{aligned}
$$

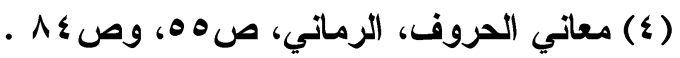

(0) انظر : البرهان، الزركثي، VT/r. وبحث "هل في القرآن الكريم من أحرف الزيادة"، علي

$$
\begin{aligned}
& \text { النجدي ناصف. }
\end{aligned}
$$

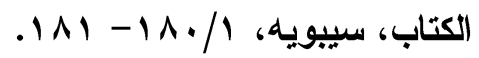

سر صناعة الإعراب، ابن جني، / (V)

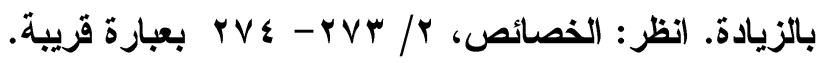




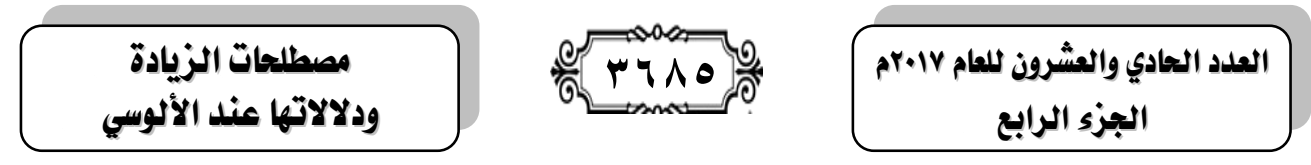

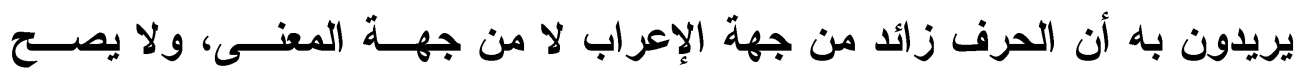

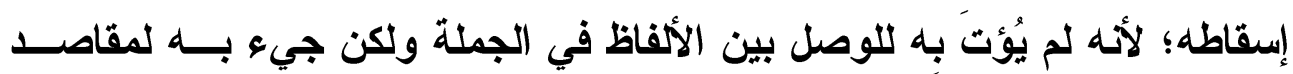

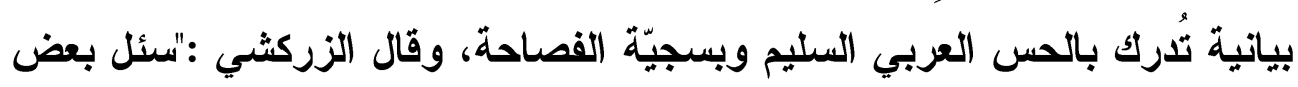

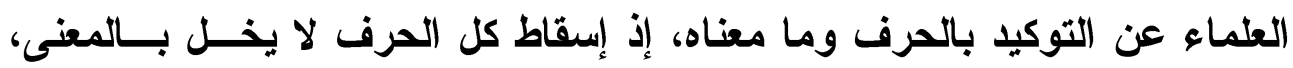

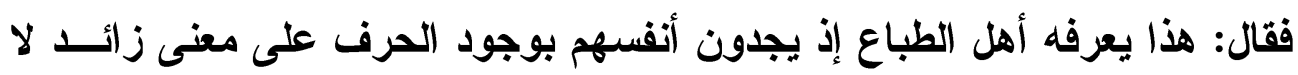
يجدونه بإسقاط الحرف"(1).

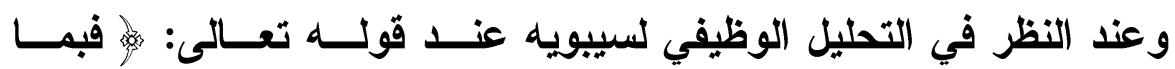

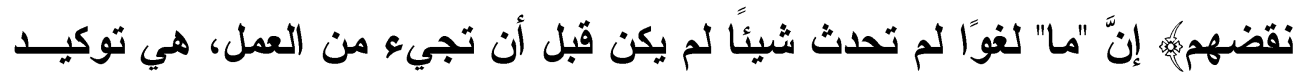

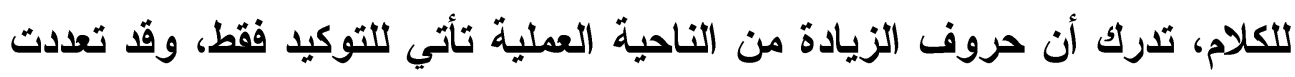

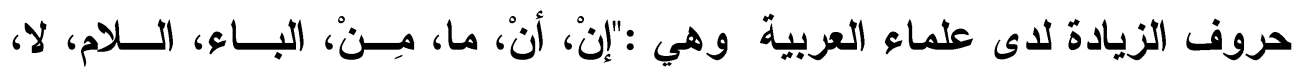

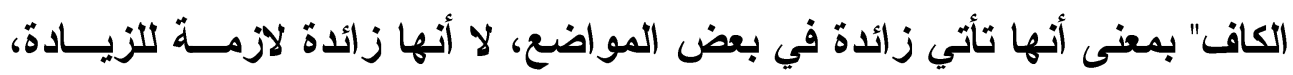

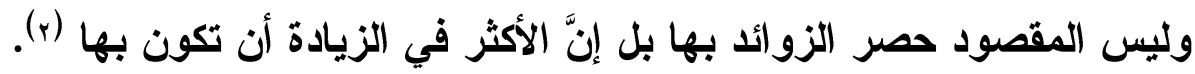

وقال السيوطي :"قال الزمخشري(r) في المفصَّل: حروف الصلة: أن، وأنَّ،

$$
\text { وأنَّ، وما، ومنْ، والباءه" (؛). }
$$

وما دفعني إلى الكتابة بهذا البحث إثثارة الأستاذ الاكتور محمود فجال إلى الثى تفرد الألوسي بمصطلح جديد في التعبير عن الزيادة وهو " سيف خطيب "؛ تلطفًا

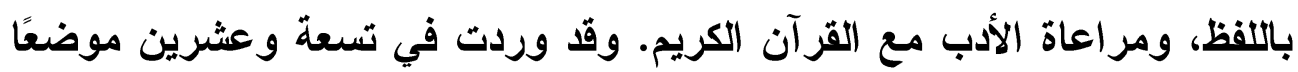

$$
\begin{aligned}
& \text { (1) البرهان، الزركثي، ع/ § V. }
\end{aligned}
$$

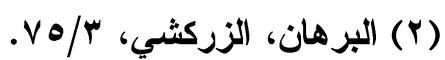

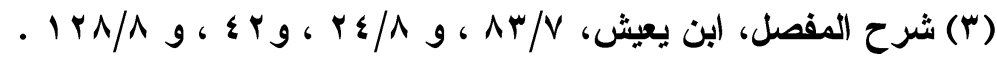

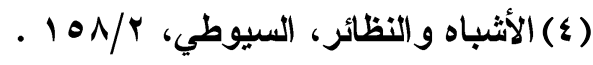




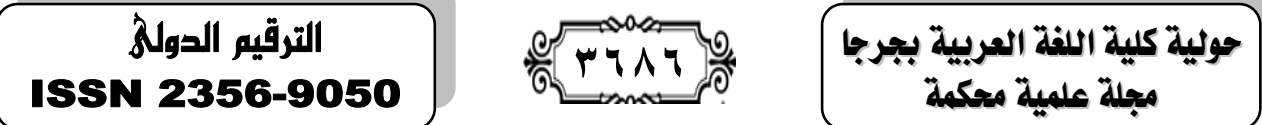

في تفسيره، وثلاثة مواضع في حاثية الألوسي علــى القطــر، وكـــلك إثـــارة الألمسي إلى معان جديدة للزيادة غير التوكيد.

لذا حاولت في بحثي هذا أن أضع القارئ أمام صورة جديدة مسن صــور حديث علماء التفسير واللغة عن حروف الزيادة، وذلك بالحديث عن الزيادة عنـــ

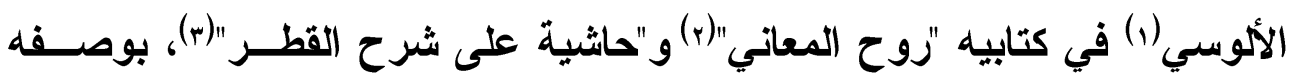

(1) الألوسي: هو محمود بن عبد الله الحسيني الألوسي، شهاب الدين، أبو الثناء: المفسر، والأديب، من المجددين البغدادي مولدًا ونثأة. ونسب إلى "ألوس" بالقصر على الأصح، وهي قرية في وسط نهر الفرات على خمس مراحل من بغاد، وتتبع محافظة الأببار الآن.

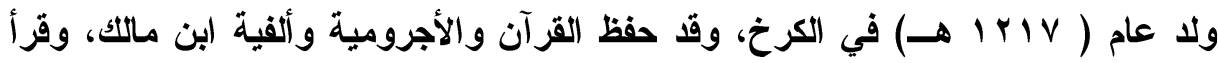
غاية الاختصار في الفقه الثافعي، وحفظ متن الرحبية كل ذلك ولم يتجاوز السابعة من

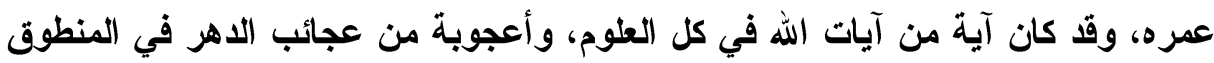
منها والمفهوم، وكان في غاية الفصاحة و البلاغة، وله العديد من المؤلقات والمصنفات

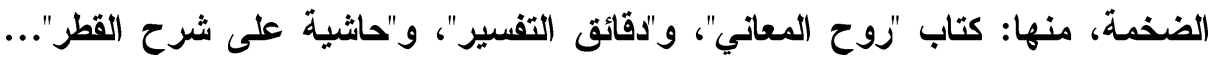

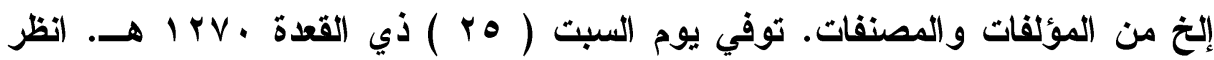

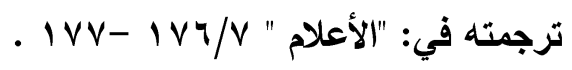

(r)واسمه "روح المعاني في تفسير القرآن العظيم والسبع المثاني"، وهو كتاب يجمع بين التفسير بالمأتور والتفسير بالرأي، ويشتمل على آراء السلف رواية ودراية، وأقوال

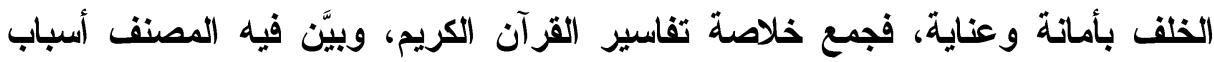
النـزول، والمناسبة بين السور، والمناسبات بين الآيات، وعرض لذكر القراءات،

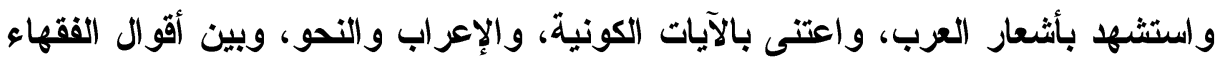
وأدلتهم في آيات الأحكام، ورجح بينها من دون تعصب لمذهب فقهي معين، والكتاب مكتمل ومرتب وفق ترتيب سور القرآن الكريم.

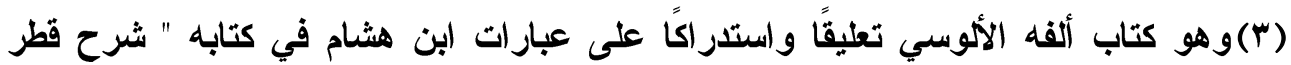
الندى وبل الصدى "، وأكمله ابنه وسمى التكملة بـ"الطارف والتالد في إكمال حاثية

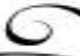




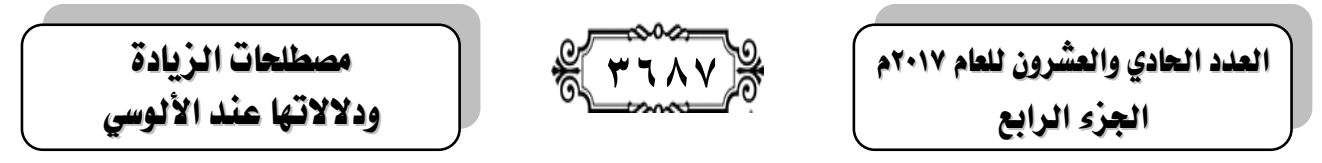

مفسرًا ونحويَّا، فما المصطلدات التي عبَّر بها الألوسي عن الزيادةٌ؟ وما معنـى

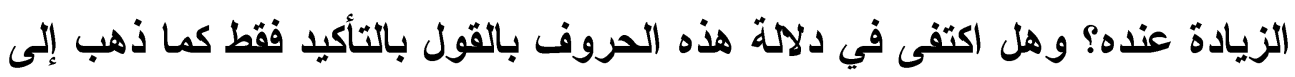

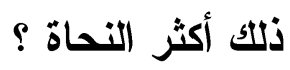

ولم يعالج هذه القضية أحد من قبل - حسب بحثي واطلاعي - فــرغم أنَّ

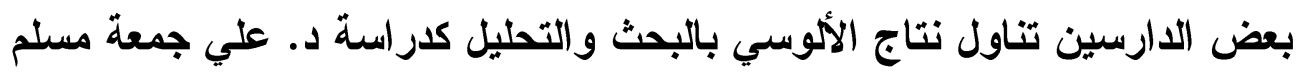

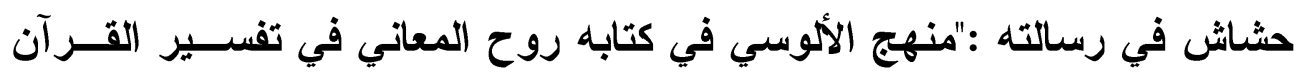

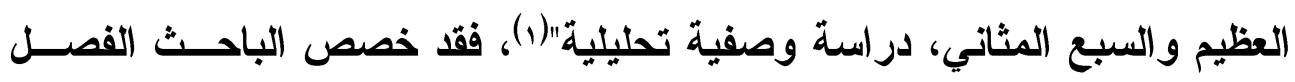

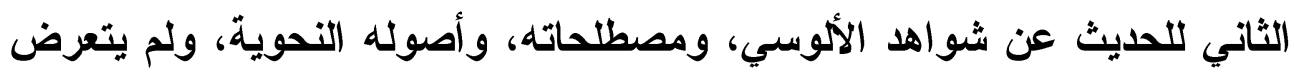

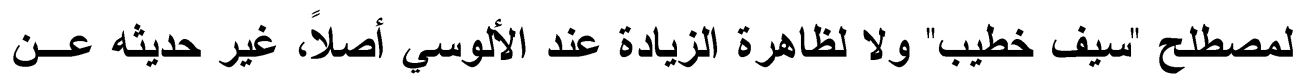
"من" بين الزيادة و التبعيض "ص الب ب ا"، وليست مما نحن بصدده في هذا البحث.

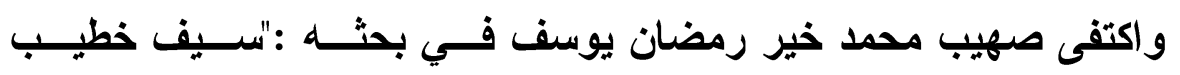

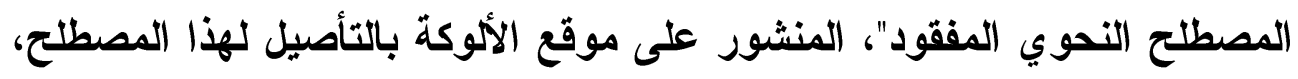

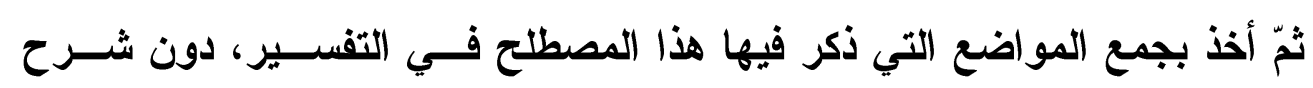

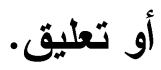

(1) رسالة علمية قمها الباحث علي حشاش للحصول على درجة الماجستير في الجامعة

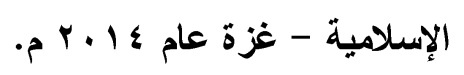




\section{الترقير الدولخ \\ ISSN 2356-9050 \\ [4⿻ \\ حولية كلية اللفة العربية بجرجا \\ مجلة علمية محكمة}

\section{همطات الزبلادة}

\section{عند الألهوسي في تفسيره روح المعاني وحاشية القطر:}

عبر الألوسي في تفسيره "روح المعاني في تفسير القرآن العظـيم" عــن

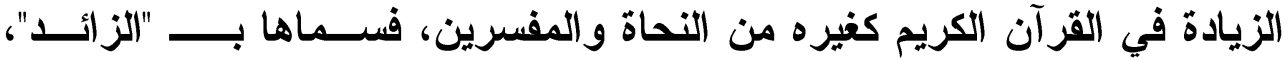
و"الصلة"، و"المقحم"، وتفرد بمصطلح رابع ألا وهو "سيف خطيب"، وســنتناولها بالبحث و الدر اسة.

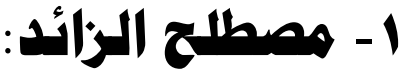

تعارف اللغويون على مصطلح "الزيادة" بهذا اللفظ لأنه لا يتغيّـر بسـببه

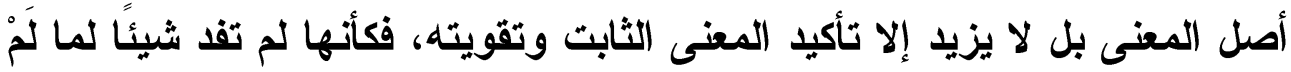

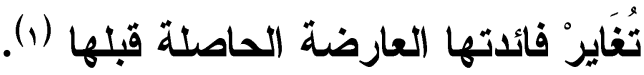

وأكثر ما عبرّ الألوسي في تفسيره عن حروف المعاني الزائدة في القرآن الكريم بمصطلح "زائد"، فقد كان يطلق حكمًا على الحرف، أو يطلق عليها الزيادة وينقل حكم العلماء عليها، أو ينقل عن غيره من التحاة والمفسرين حكم الزيــادة

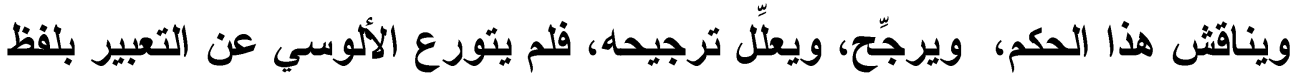
"زائد" في كلام الله - عزَّ وجل - لأنه يعرف معناها حق المعرفة، وهذه الحروف لرفي

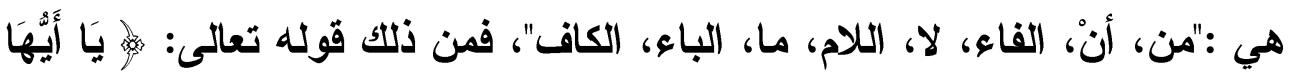

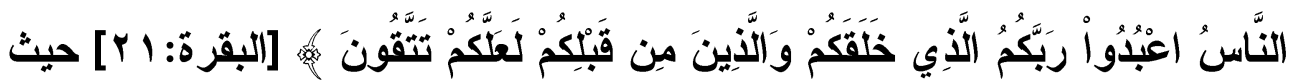

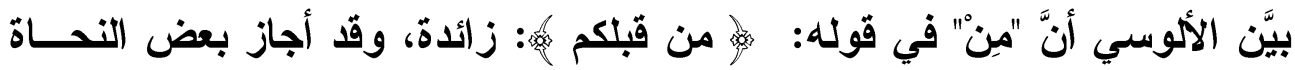

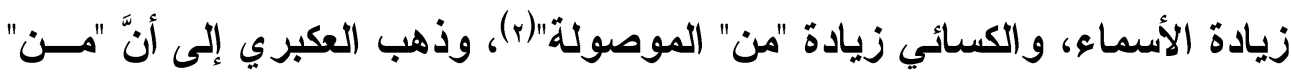

(1) الأشباه و النظائر، السيوطي، / 17 / 17 . (r) روح المعاني، الألوسي، 110/1 . 

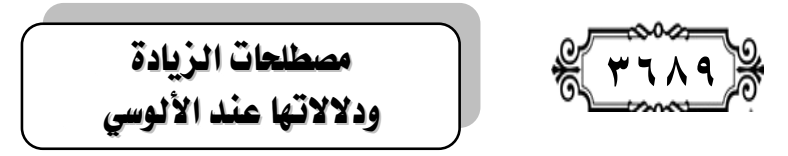

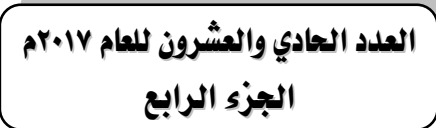

هنا لابتداء الغاية الزمانية، والتقدير: والأي خلقهم من قبل خلقكم، فحذف الخلـق

وأقام الضمير مقامه (1).

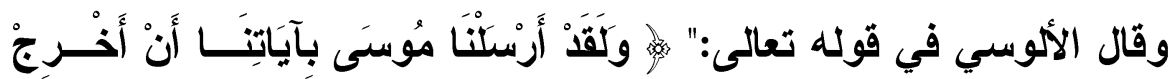

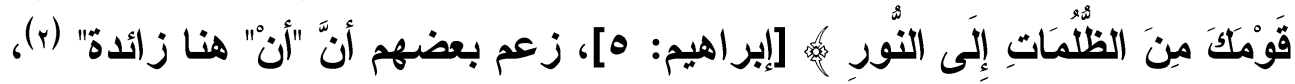
وذهب ابن كثير إلى أنها تصلح أن تكون مفسرة بمعنى أي، ويكون المعنى: ولقد

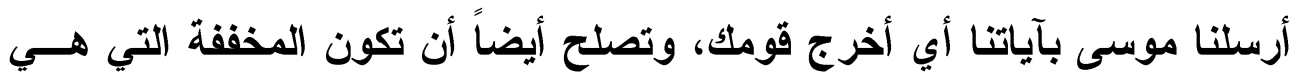
للخبر، والمعنى: أرسلناه بأن يخرج قومه، إلا أن الجار حذف ووصلت "أن" بلفـــ الأمر، ونظيره قولك: كتبت إليه أن قم، وأمرتهه أن قم(r)، قال العكبري :"أن" بمعنى إنى "أي"، فلا موضع له، ويجوز أن تكون مصدرية، فيكون التقدير بأن أخرج (ء).

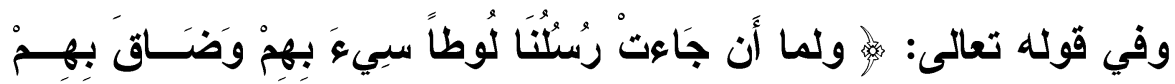

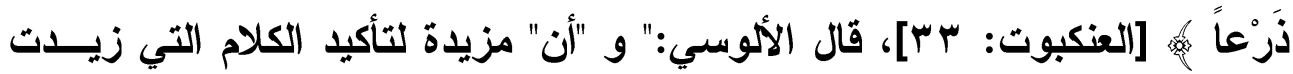

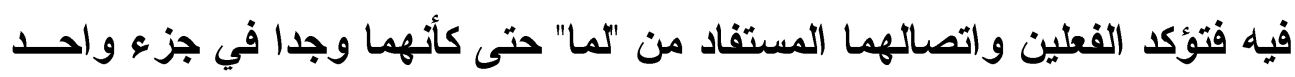

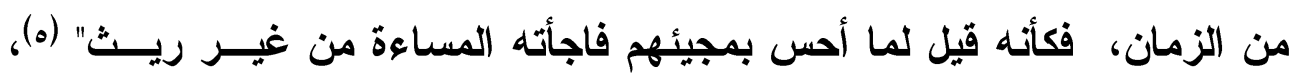

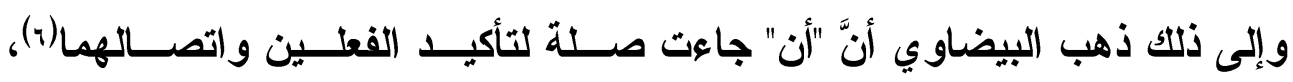

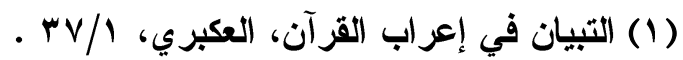

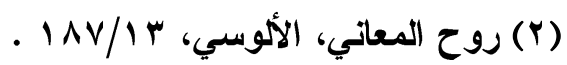

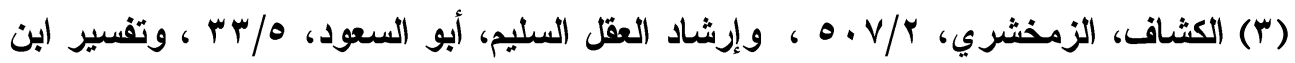

$$
\begin{aligned}
& \text { كثير، } 99 / 19
\end{aligned}
$$

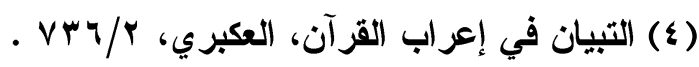

$$
\begin{aligned}
& \text { (0)روح المعاني، الألوسي، • 100/\% . }
\end{aligned}
$$

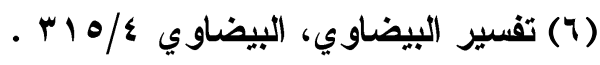




\section{الترقيم الدوله}

ISSN 2356-9050
T)
حولية كلية اللفة العربية بجرجا مجلة علمية محكمة العربة بحتر

و إلى ذلك ذهب السمين الحلبي(1)، وقال ابن هشام:" ولا معنى لـــ "أن" الزائدة غير التوكيد كسائر الزوائد، وقال أبو حيان: وزعم الزمخثري(r) أنه ينجر مع التوكيد

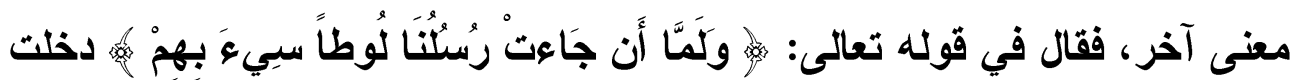

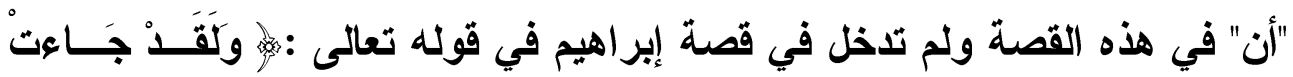

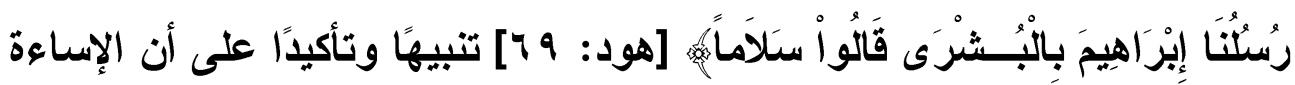
كاتت تعقب المجيء، فهي مؤكدة في قصة لوط للاتصال و اللزوم، وليست كذلك في قصة إبر اهيم إذ ليس الجواب فيها كالأول" (؟).

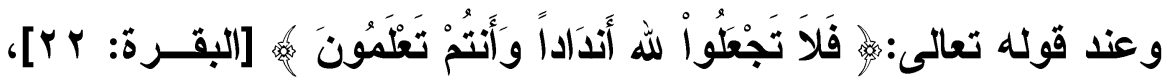
قال الألمسي :"ويحتمل أن تكون الفاء زائدة مشعرة بالسببية"(؛)، وذكر الســمين الحلبي: إنَّ الفاء هنا للتسبُبِ، أي: تَسَبَّبَ عن إيجادِ هذه الآياتِ الباهرة النهيُ عن

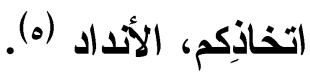

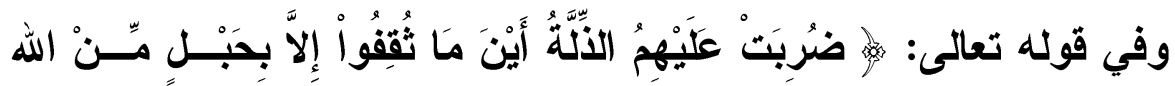

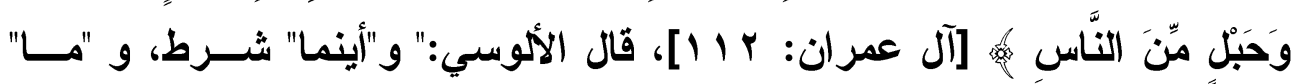
زائدة، و"ثقفوا" في موضع جزم، وجواب الثرط محذوف يدل عليه ما قبله، أو هو

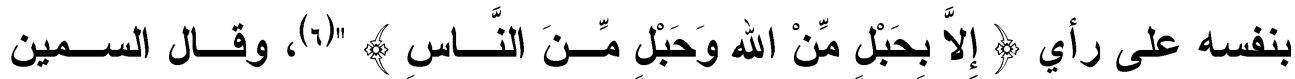

(1) الار المصون ، السمين الحلبي، $19 / 9$ ـ (19)

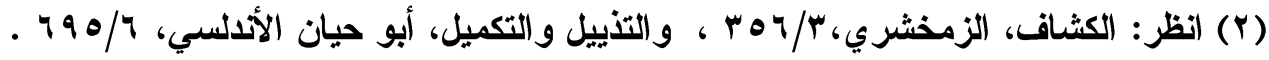

(r) مغني اللبيب، (بن هشام، ص rه ـ

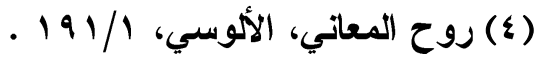

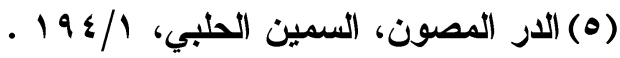

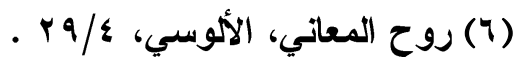


الحلبي:" أينما" شرط، وهي ظرف مكان، و "ما" مزيدة فيها (1).

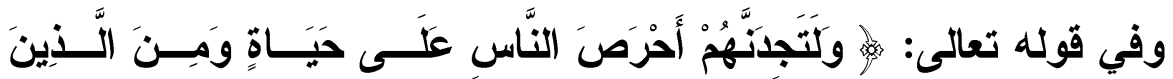

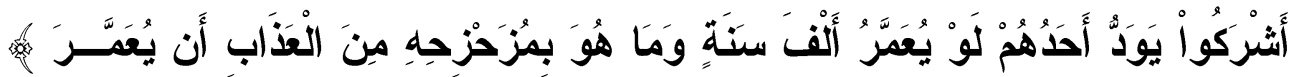
[البقرة: ج4]، قال الألوسي:" ما" حجازية أو تميمية، و "هو" ضمير عائد إلــى "

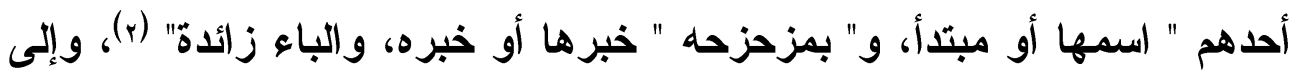

ذلك ذهب أبو السعود في تفسيره (r).

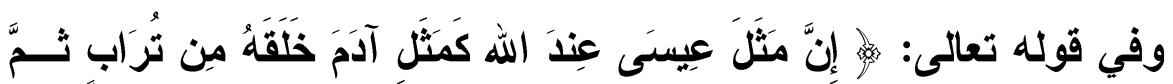

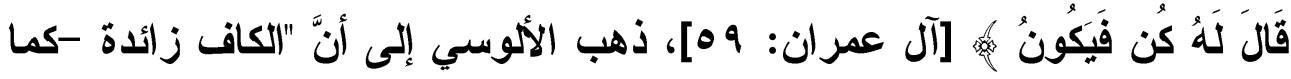
قيل به - بل بمعنى الحال" (ع).

(1) الار المصون، السمين العلبي، r/ ror ـ .

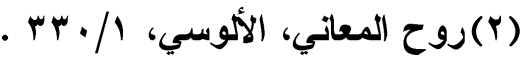

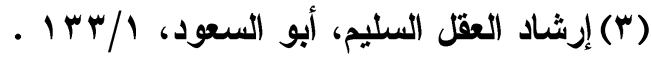

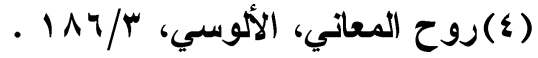




\section{الترقيم الدولخ}

ISSN 2356-9050
क.

حولية كلية اللفة العربية بجرجا

مجلة علمية محكمة

\section{:}

ويطلق على ظاهرة الزيادة في حروف المعاني مصطلح "(لصــلة"؛ لأهـــه

يتوصل بها إلى زيادة الفصاحة أو إلى إقامة وزن أو سنجْعِ أو غير ذلت (1).

وقد استخدم الألموسي في تفسيره مصطلح "الصلة"؛ للتعبير عـن حسروف المعاني الزائدة في القرآن الكريم، ويأتي هذا المصطلح في الدرجة الثانية في عدد مرات الاستخدام عنده بعد مصطلح "الزيادة"، فمن ذلك:

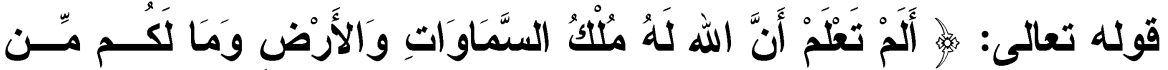

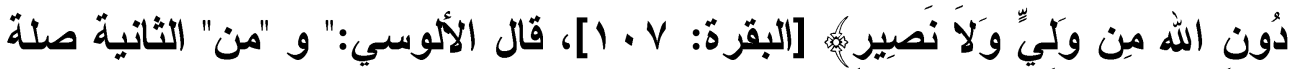
فلا تتعلق بشيء، و "من" الأولى لابتداء الغاية، وهي متعلقة بمحذوف وقع حـالاً

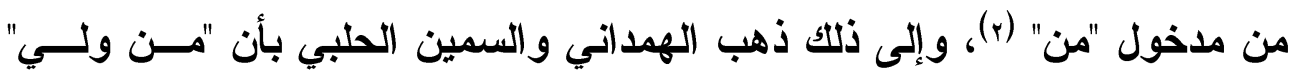

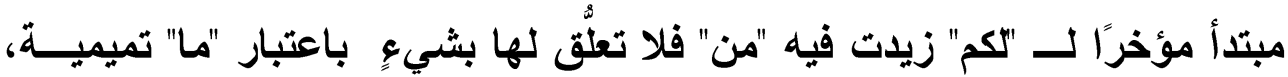
وتكون "من ولي" اسمها مؤخرًا باعتبار "ما" حجازية و "من" فيه زائدة (r).

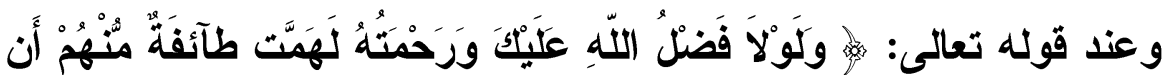

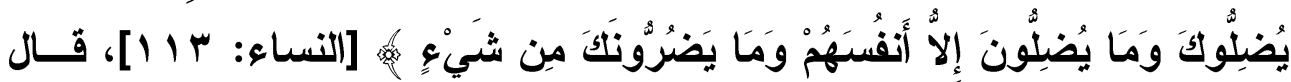

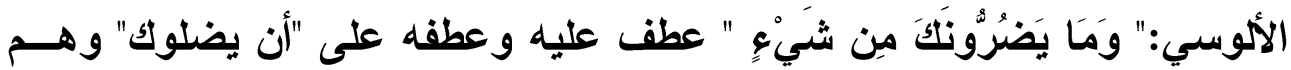

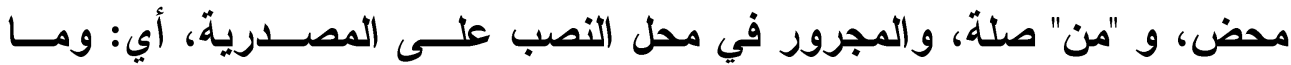

(1) الأثباه و النظائر ، السيوطي، / 17 ـ ـ

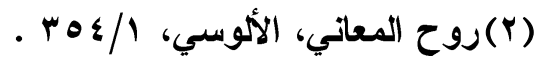

(T) انظر: الفريد في إعراب القرآن، الههذاني، /هo/1 ، و والدر المصون ، السمين الحلبي، 


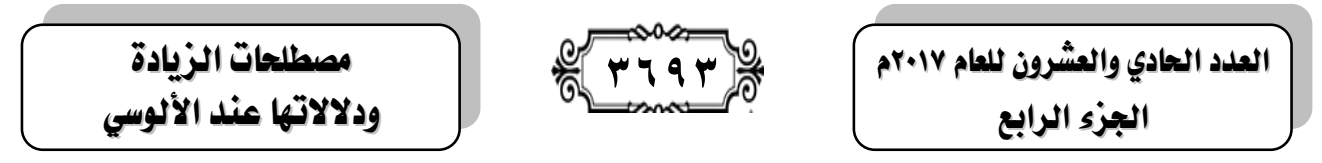

يضرونك شيئًا من الضرر، لما أنه تعالى عاصكك عن الزيغ في الحكم..."(1)، وإلى لم

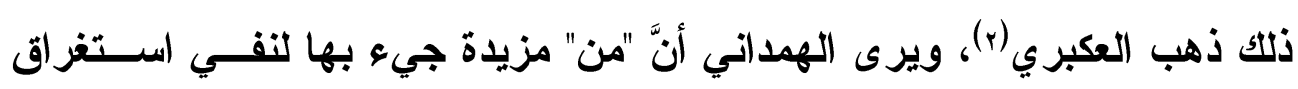

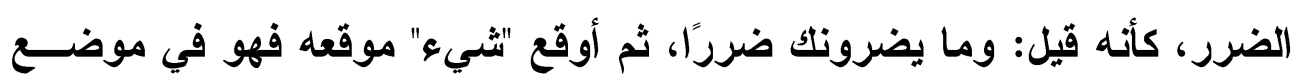
نصب لوقوعه موقع المصدر (r).

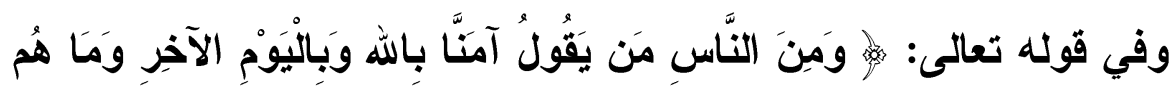

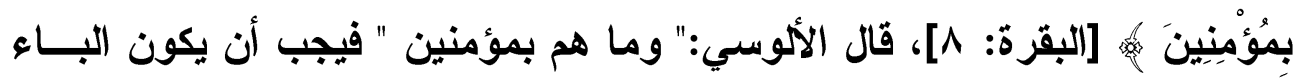

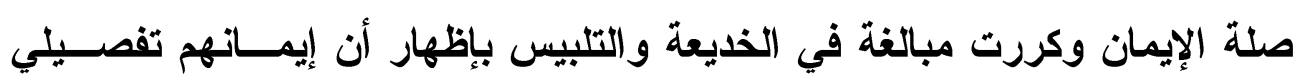

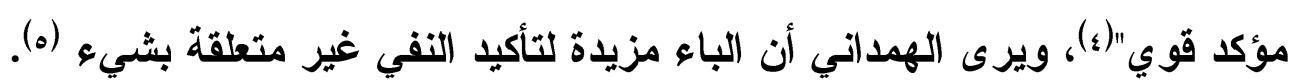

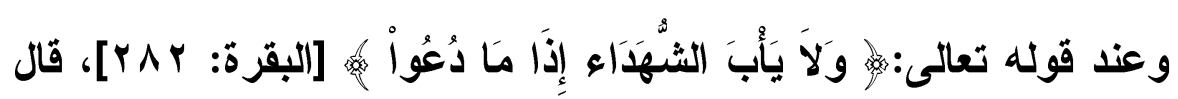

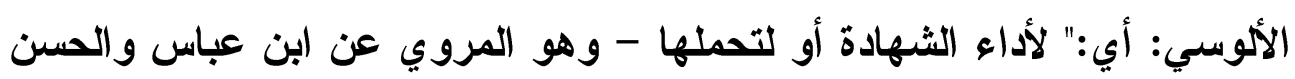

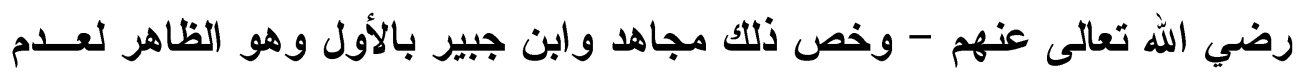

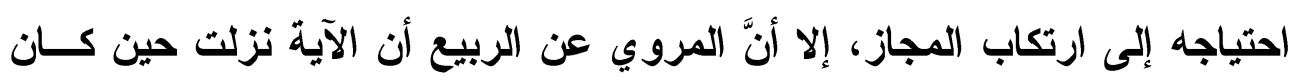

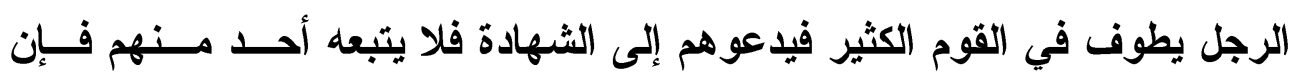

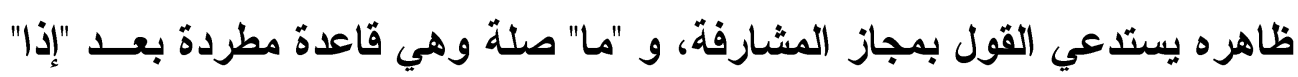

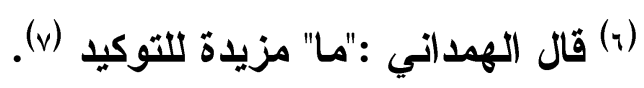

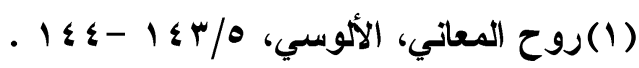

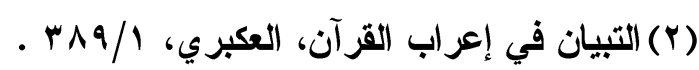

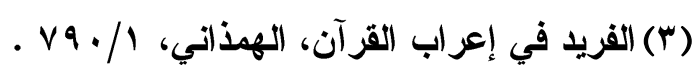

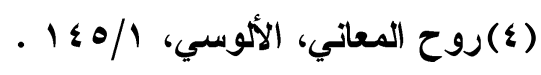

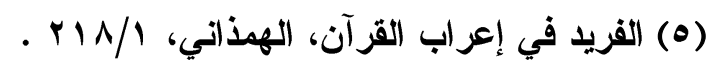

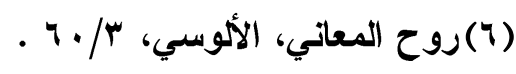

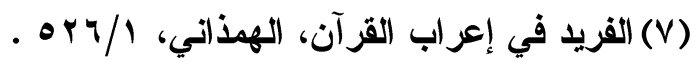




\section{الترقيم الدولخ}

ISSN 2356-9050

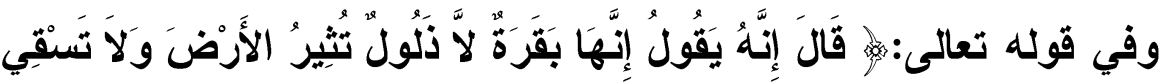

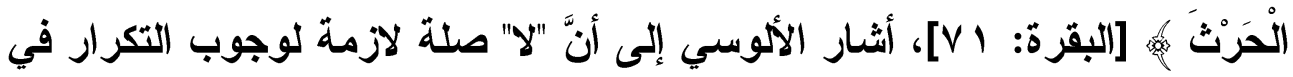
هذه الصورة، وهي مفيدة للتصريح بعموم النفي إذ بدونها يحتمل أن يكون لنفـي

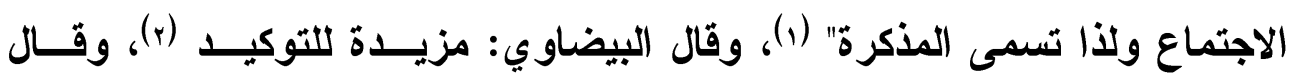
النسفي :"لا" الأولى نافية، والثانية مزيدة لتوكيد الأولى؛ لأنَّ المعن: لا ذلول تثير” الأرض أي: تقلبها للزراعة وتسقى الحرث، على أن الفعلين صفتان لألول كأنـــه قيل لا ذلول مثيرة وساقية (r).

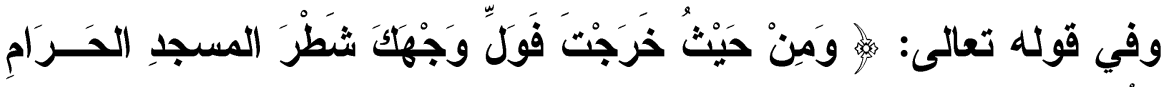

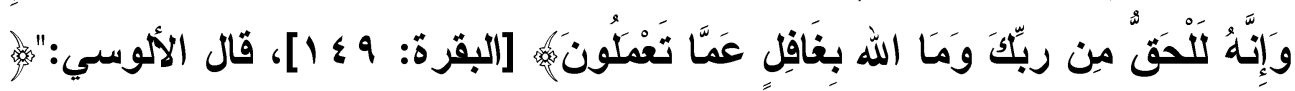

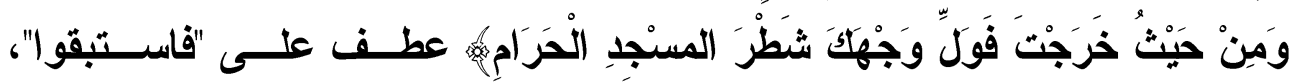
و"حيث" ظرف لازم الإضافة إلى الجمل غالبًا، والعامل فيها ما هو في محل الجزاء لا الثرط فهي هنا متعلقة بـ "ول"،، والفاء صلة للتبيه على أن ما بعدها لازم لما

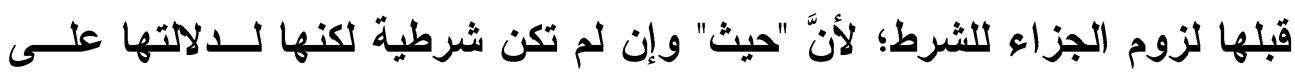
العموم أثببهت كلمات الثرط فقيها رائحة الثرط، ولا يجوز تعلقها بــ "خرجــت

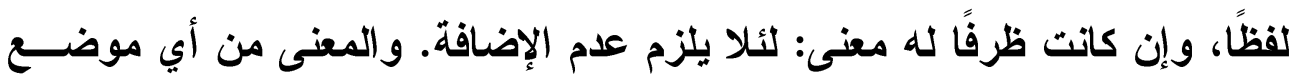
خرجت فول وجهك" (ع).

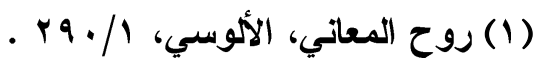

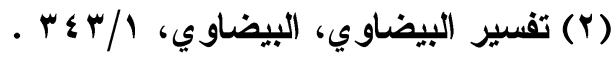

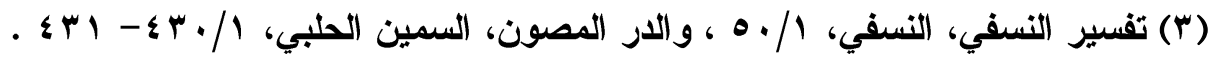

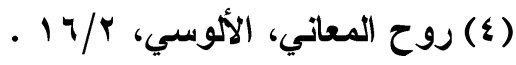




\section{مصطاحات الزيادة \\ ودلالاتها عند الألوسي}

استخدم الألوسي في تفسيره مصطلح "مقحم" للتعبير عــن الزيــادة فـي حروف المعاني في القرآن الكريم، ويأتي هذا المصطلح في الارجة الثالثة في عدد مرات الاستخدام بعد مصطلح "الصلة" و"الزيادة"، فمن ذلك:

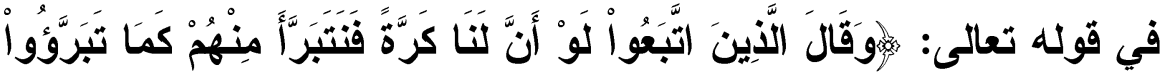

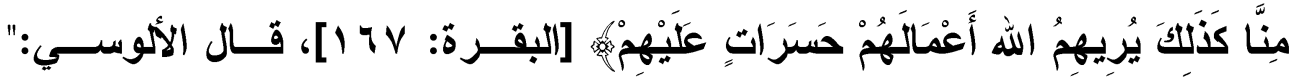
كذلك"... و الكاف مقحمة لتأكيد ما أفاده اسم الإثـارة من الفخامة ومحله النصــب على المصدرية أيضًا، أي: ذلتك الإراء الفظيع يريهم على حد ما قيل فــي قولــه. تعالى: في قوله تعالَى:

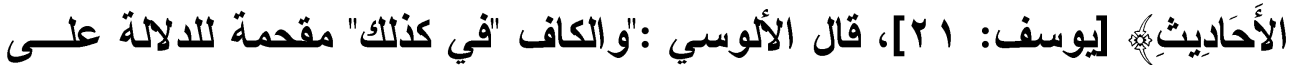
تأكيد فخامة شأن المشار إليه على ما ذكروا في " وكذلك جعلناكم أمة وسطًا "(ץ)، وقال السمين الحلبي: الكاف في "كذلك" هنا فيها قولان: أحســهما: أنَّ موضــعها

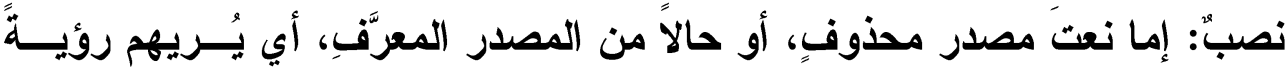
كذلك، أو يحشُرهم حشرًا كذلك، أو يجزيهم جزاءُ كذلك، أو يُريهم الإرادة مشــبهةً كذلكك ونحوُ هذا. والثاني: أن يكون موضعُها رفعًا على أنه خبرُ مبتدأ محذوفِ أي:

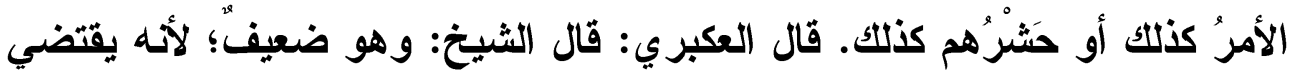




\section{الترقير الدول\$ \\ ISSN 2356-9050}

زيادة الكاف وحذف مبتدأ، وكلاهما على خلاف الأصل، والظاهر أن الكاف علـى بابها من التشبيه وأن التقدير مثل إراعَّهم تلك الأهوال (1).

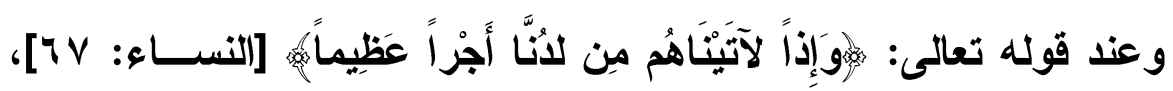
قال الألوسي :" و"إذن" مقحمة للالاحة على أن هذا الجزاء الأخير بعد ترتيب التالي السابق على المقدم، و لإظهار ذلك وتحقيقه قال المحققون: إنه جواب لسؤال مقدر

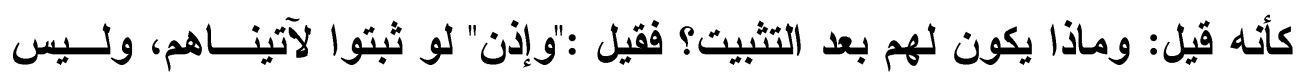

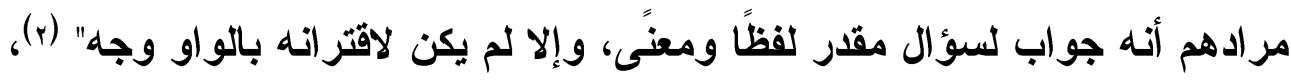
وذهب أبو البقاء العكبري إلى أن "إذن" جواب ملغاة (r).

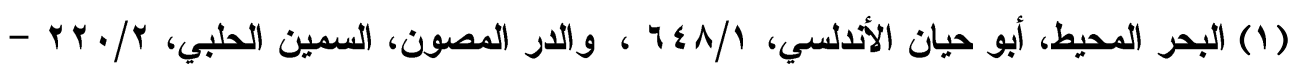
. TrI-

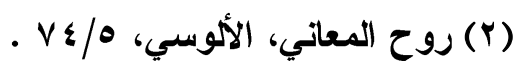

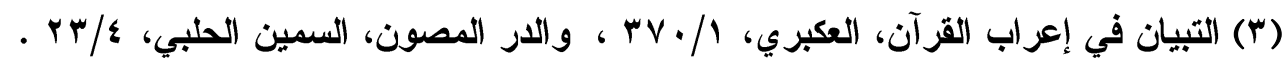

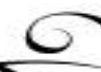




\section{مصطاحات الزيادة ودلالاتها عند الألوسي الورادي}

\section{-}

لم يسبق الألوسي أحد من أهل اللغة أو المفسرين أو من أعرب القــرآن

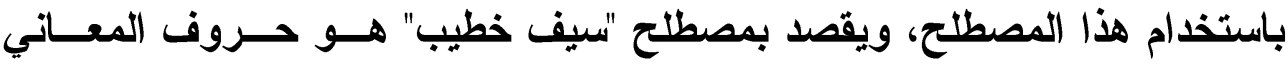

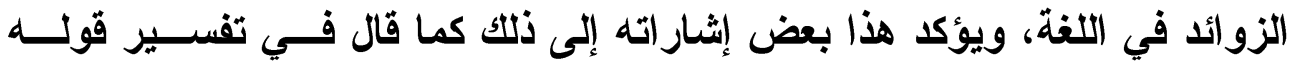

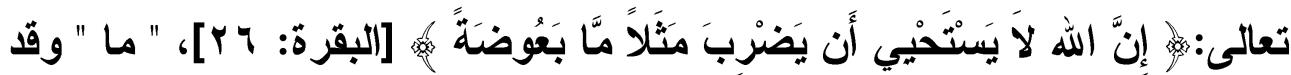
تجعل سيف خطيب، و القر آن أجل من أن يلغى فيه شيء". فقد سار على نهج غيره من النحاة حين وضعوا مصطلحًا جديدًا لحسـروفت المعاني الزوائد تـــزيهًا للقر آن الكريم بالقول بأنّ فيه زائدًا، قاصدين بذانلك التأدب

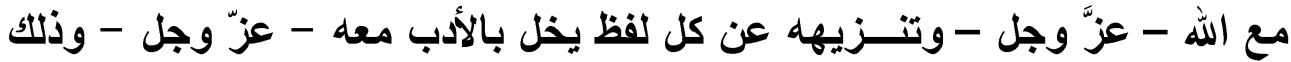
في إعرابهم للقر آن الكريم، وقد استخدم النحاة مصطلحات نحوية تعارفوا عليهـا تستخدم حين يعربون جملة متعلقة بالله - عزَّ وجل- أو أفعاله، كإطلاقهم " لفـــاه الجلالة" على "الله" ويقولون منتصب على التعظيم، وباب ما لم يسمَ فاعلــه، ولام

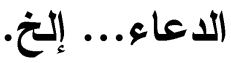

وقد استخدم الألوسي هذا المصطلح "سيف خطيـب" فـي تفسـيره "روح

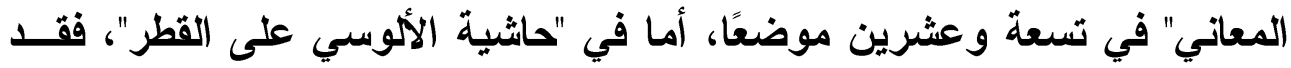

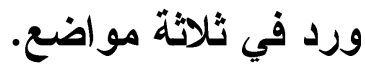

وقد تعداد معاني كلمة "سيف" في المعجم العربي، ولعلــي مسن خلالهـــا

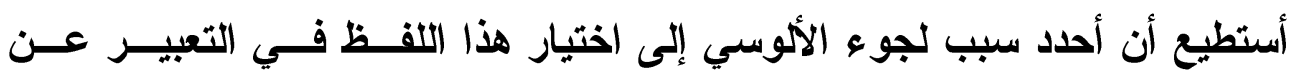

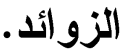

$$
\text { جاء في "لسان العرب"(1): - (1) }
$$

(1) لسان العرب، ابن منظور، مادة (سيف) . 


\section{الترقيم الدوله}

ISSN 2356-9050

1- "سيف: السيف الذي يضرب به وهو معروف، والجمع أسياف سيوف أسيف". ويقصد به أيضًا ما يفصل بين الحق والباطل.

وحمثًا على هذا المعنى لعل الألموسي قصد بـ "سيف خطيب" أن هذا هـــ الرأي الراجح عنده والأي يؤيده، وخصوصًا أن مجموعة من المواضع كانت بلفظ القيل، أو النقل عن غيره.

r- "السيّف: ما لزق بأصول السعف من خلال الليف وهو أردؤه وأخثنه وأجفاه"، واستدلَّ ابن منظور بقول الر اجز يصف أذناب اللقاح:

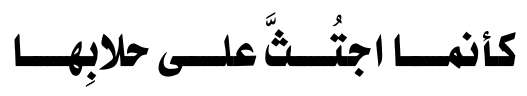

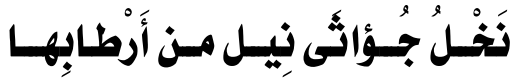

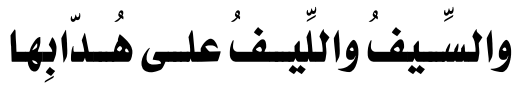

وحملًا على هذا المعنى لعل الألوسي قصد أنه حين يطلق "سيف خطيـبـ" أنه ينقل عن غيره هذا الرأي ولا يستحسنه، ولا يريد أن يصرح بلفظ الزائد، ولم أجد في المعاجم اللغوية اقتران "السيف" بــ "الخطيب".

وقصد الألوسي بـ "الخطيب" الإمام، كما قال في تفسير قولــهـ تعــالى :

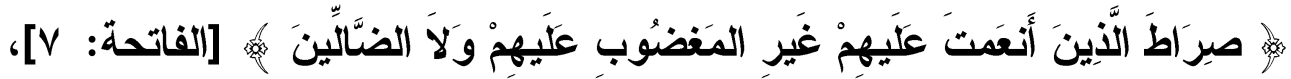
وقال :"لا" كما في الإمام وهو سيف خطيب أتى بها لتأكيد ما في "غير" من معنـى النفي، والكوفيون يجعلونها هنا بمعناها" (1). 

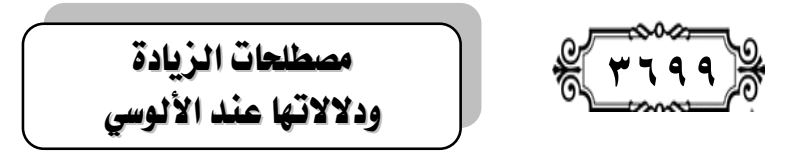

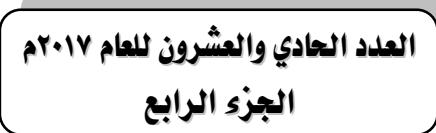

ولفظة "سيف خطيب" مأخوذة من اعتماد الخطيب على السيف في خطبتي

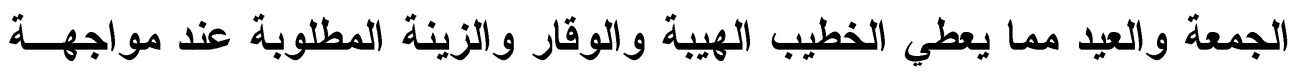
المأمومين، إلا أنَّ الحروف المذكورة على أنها "سيف خطيب" هي حروف ركسيائز معنوية يستعين بها الكاتب بوصل الكلام بعضه ببعض وتأكيل المعنى. وقد سمى أبو العلاء المعري كتابًا له بــ "سيفُ الخطيبِ" (1).

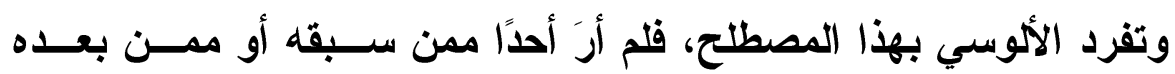

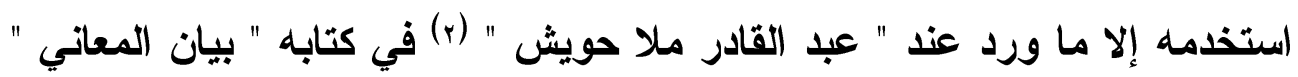

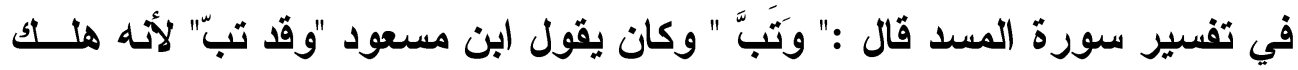
حقيقة، ولا تجوز القراءة بها؛ لما فيها من الزيادة، وهي عبارة عن كلمة قالهــا

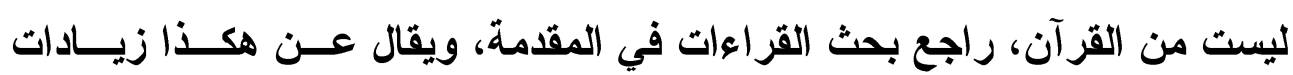

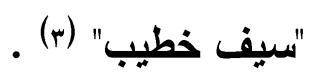

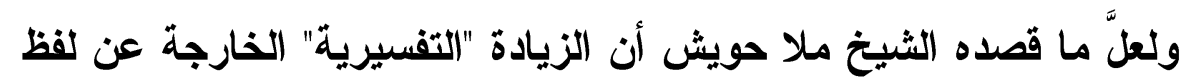

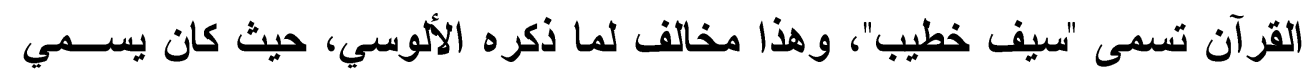
الحرف الزائد في بعض المواضع بــ "سيف خطيب" مع وجوده في الآية أصلًا .

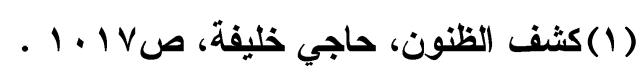

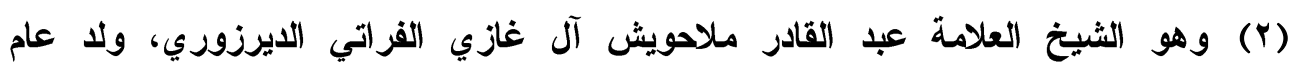

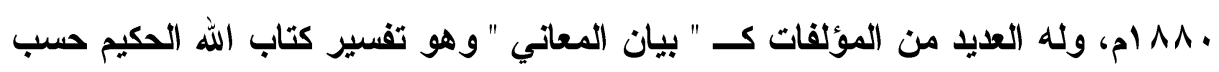

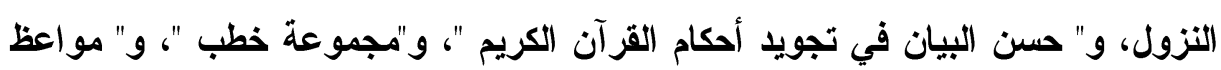

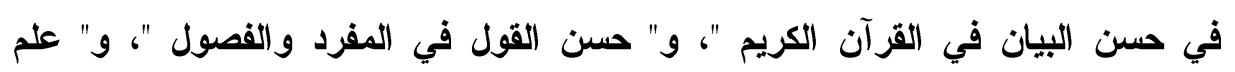

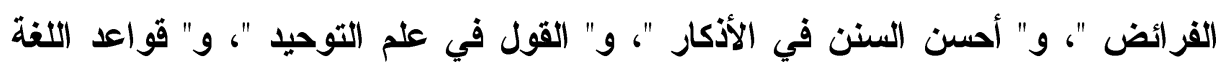

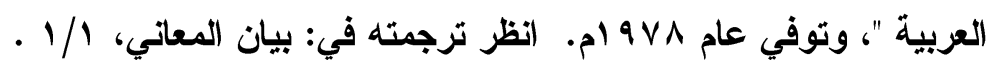

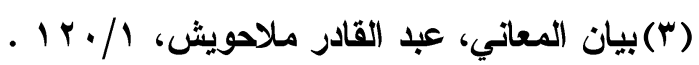




\section{الترقيم الدولم ISSN 2356-9050}

\section{هواضع ورود "سيف خطيبب" عند الألموسي:}

بعد استقراء كتابي " روح المعاني "و" حاشية الألوسي على شرح القطر

" وققت على اثثين وثثلاثين موضعًا ذكر فيه الألوسي مصطلح " سيف خطيـب "،

منها تسعة وعشرون موضعًا في " روح المعاني " وثلاثة مواضع فـي " حاثــية

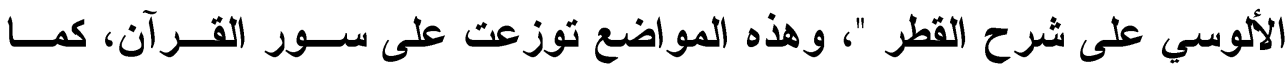
تنوعت في استخدامها، فتارة يطلقها على زيادة الباء، ولا، وما، والــلام، ومــن، والواو، والقاء، وسأورد هذه المواضع على النحو الآتي:

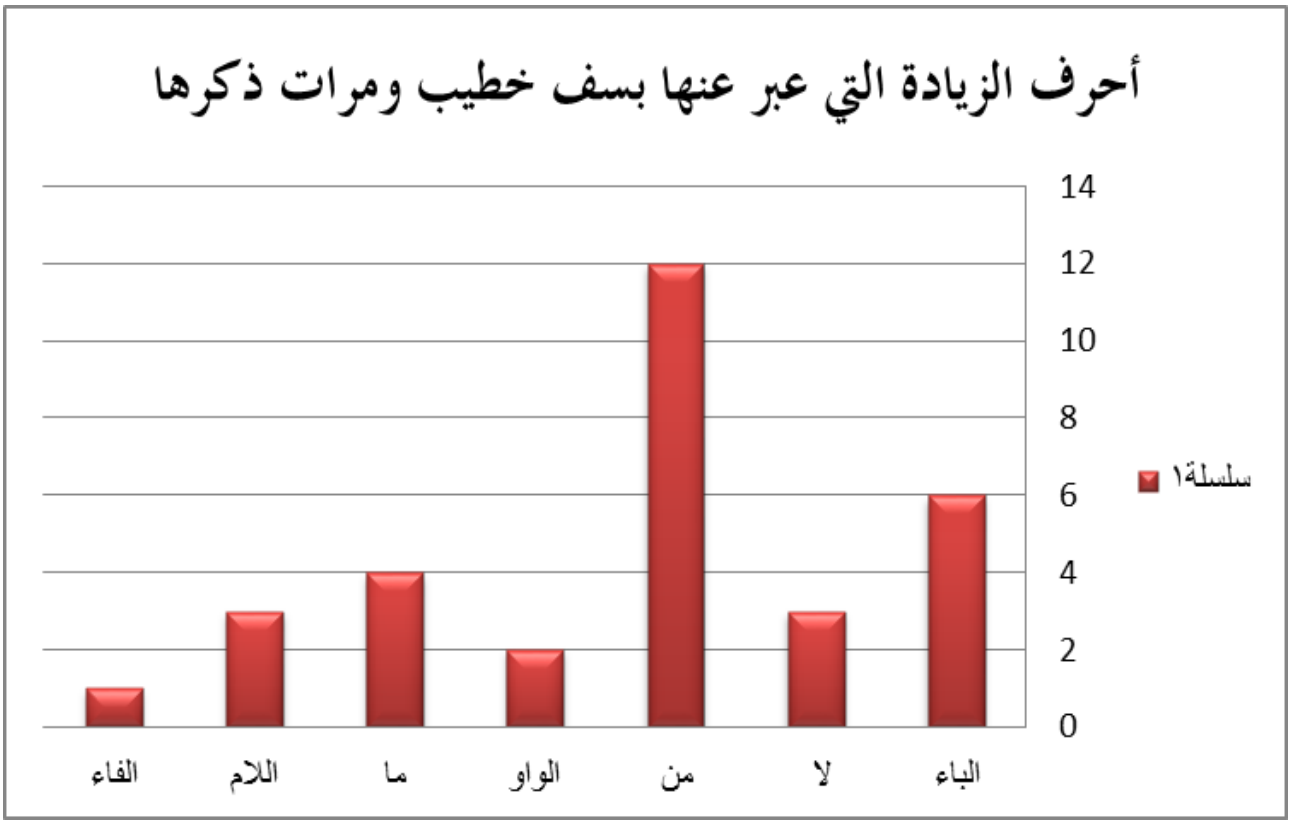




\begin{tabular}{|c|c|c|}
\hline ودلالاتها عند الألوسيادة & & \\
\hline & عدد المرات & الحرف \\
\hline & 7 & الباء \\
\hline & $r$ & $\gamma$ \\
\hline & ir & هن \\
\hline & $r$ & الهواو \\
\hline & $\varepsilon$ & Lo \\
\hline & $r$ & IلIJ \\
\hline & 1 & |لنفاء \\
\hline
\end{tabular}

\section{أولاً: في تفسيره روح المعاني:}

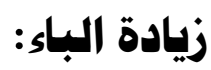

ذهب النحاة إلى أنّ الباع تز اد في ستة مواضع، على النحو الآتي:

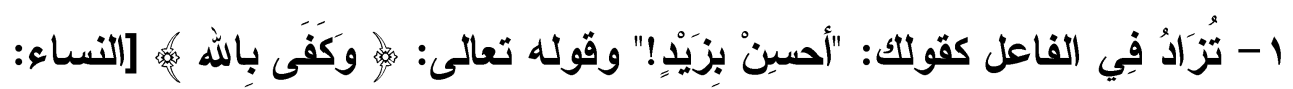
ج]، أي: كفى الله (1).

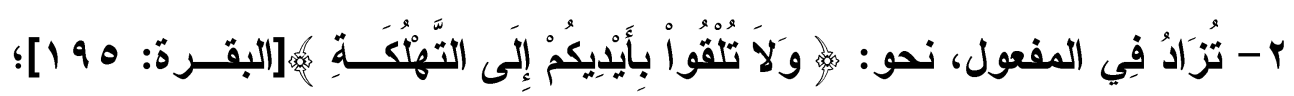

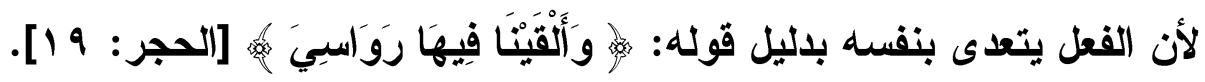




\section{الترقيم الدوله \\ ISSN 2356-9050}

r- تزاد فَفي المبتدأ، وهو قليل ومنه عند سبيويها

$$
\text { ونحو : بحسبك درهم . }
$$

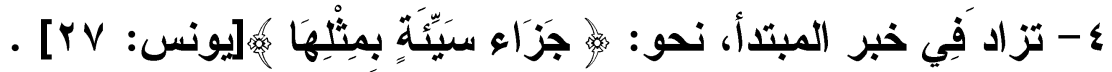

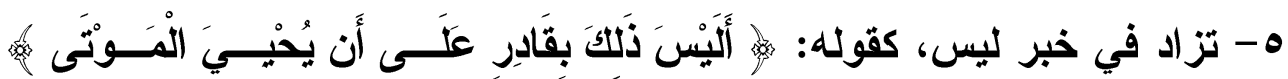

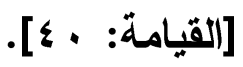

وأطلق الألموسي على "الباء" الزائدة مصطلح سيف خطيب، وذلـــــــي

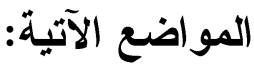

ا - عند تفسير قوله تعالَى:

الألوسي:" بولاها "... والباء على كل تقدير سببية، ولك أن تجعل فاعـل بمعنــى فعل، والباء سيف خطيب، ويكون المعنى: لا تضر والدة ولاها بأن تشيء غـــاعه وتعهله وتفرط فيما ينبغي له وتدفعه إلى الأب بعدما ألفها، ولا يضر الوالد ولــــه

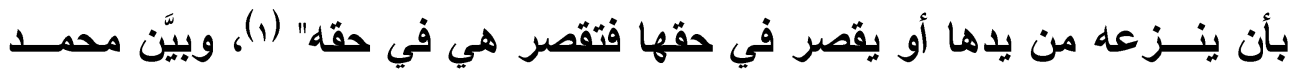

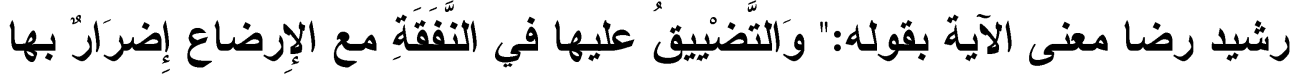

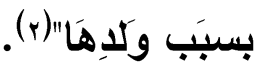

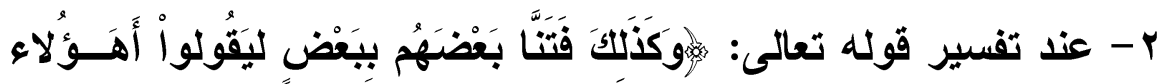

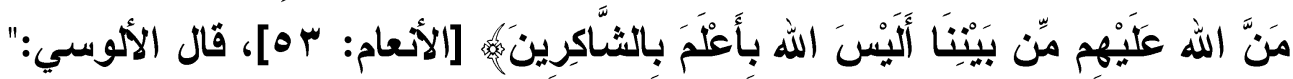

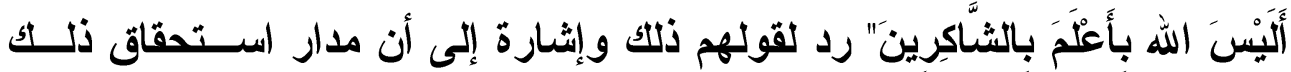
الإنعام معرفة شأن النعمة والاعتر اف بحق المنعم، والاستفهام للتقريز بعلمه البالغ بذلك، والباء الأولى سيف خطيب، والثانية متعلقة بأعلم، ويكفي أفعل العمل فـي

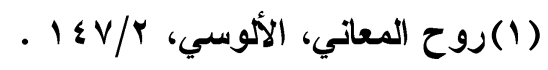

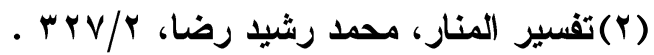



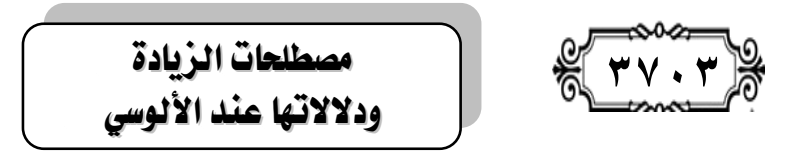

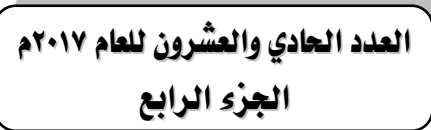

مثثل"، وفي الدر المصون "العلم" يتعدى بالباء لتضمنه معنى الإحاطة وهو كثير في

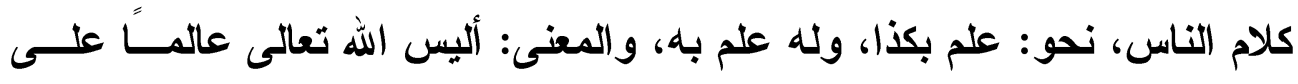

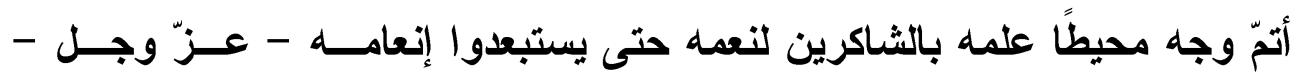

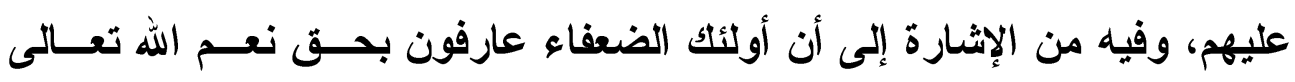

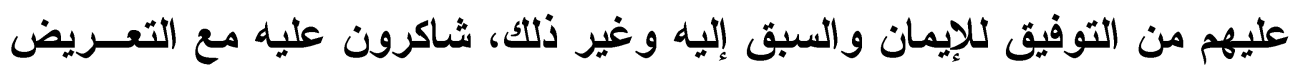
بأن القائلين في مهامه الضلال بمعزل عن ذلك كله ما لا يخفى" (1).

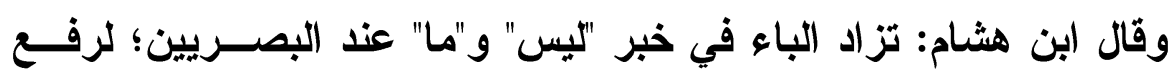

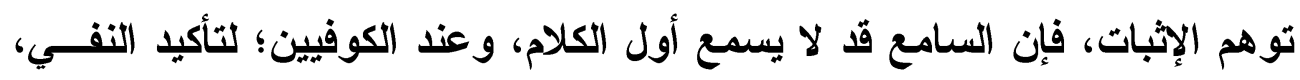

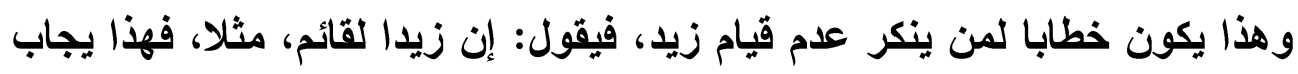
بليس زيد بقائم باتفاق وبكثرة، فهي تفيد تأكيد النفي (r).

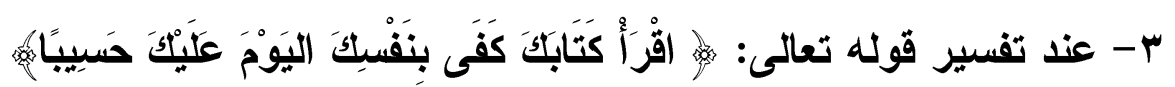

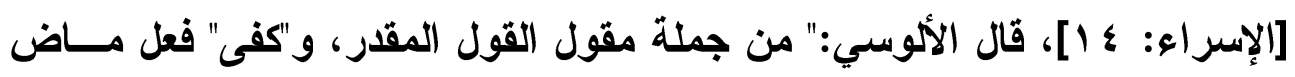
و"بنفسك" فاعله، و الباء سيف خطيب وجاء إسقاطها ورفع الاسم كما في قوله:

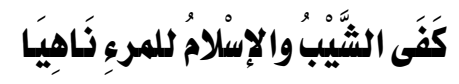
وقوله:

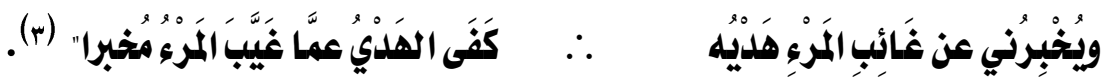

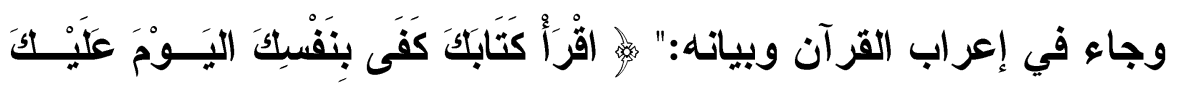

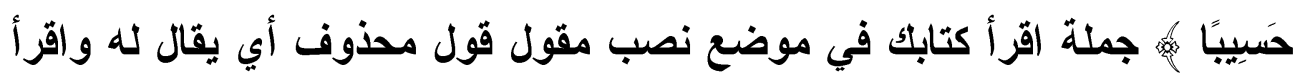

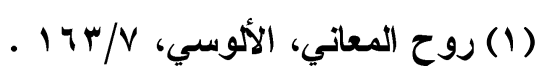

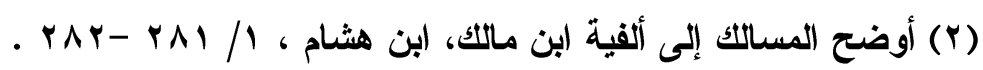

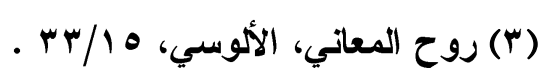




\section{الترقيم الدولخ}

ISSN 2356-9050

فعل أمر وفاعله مستتر تقديره أنت وكتابك مفعول به وكفى فعل ماض وبنفســك الباء حرف جر زائد، ونفسك فاعل مرفوع محلا مجرور بالباء لفظا واليوم ظرف متعلق بمحذوف حال وعليك متعلقان بحسيبا، وحسيبا تمييز وهو بمعنى حاســب كما ذكر سيبويه"(1).

ع- عند تفسير قوله تعالى

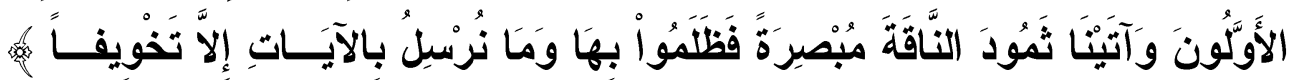
[الإسراء: 9ه]، قال الألوسي:" ونصب "تخويفًا" على أنه مفعول لــه، وجـــِّ أن يكون حالاً أي مخوفين، و "الباء" في الموضعين سيف خطيب، و"الآيــات" مفعــول

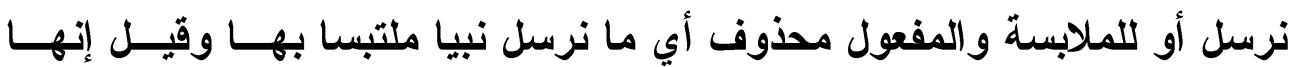
للتعدية وأن أرسل يتعدى بنفسه وبالباء..." (؟).

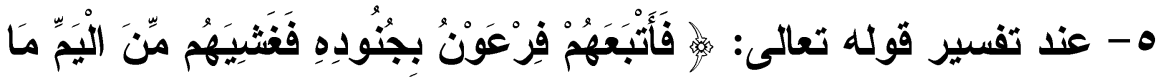

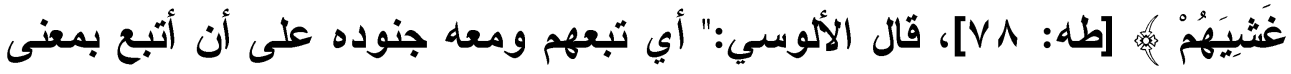
تبع، وهو متعدٍّ إلى واحد، والباء للمصاحبة والجار والمجرور في موضع الحــال،

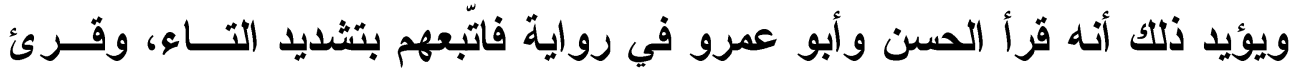
أيضًا:" فأتبعهم فرعون وجنوده"، وقيل: أتبع متعدٍّ إلى اثنين ...، والثاني: مقدر، أي: فأتبعهم رؤساء دولته أو عقابه، وقيل: نفسه والجار والمجرور في موضــع الحال أيضًا، وعن الأزهري أن المفعول الثاني جنوده، و"الباء" سيف خطيـبـ أي أتبعهم فرعون جنوده وساقهم خلقهم" (؟).

(1) إعراب القرآن وبياته، محيي الاين درويش، ه/ . . ـ .

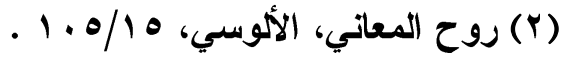

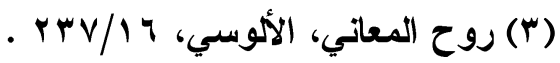

\section{0}




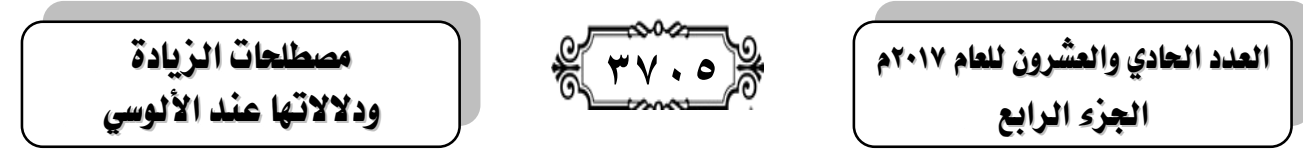

وقال القرطبي:" ومن قطع" فَأَتْعَع" يتعدَّى إلَى مفعولين: فيجوز أَنْ تَكـون

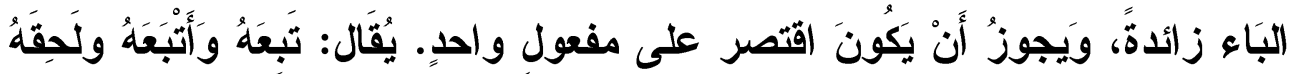

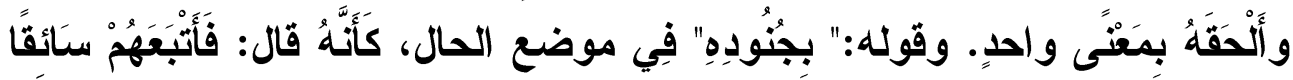

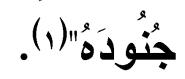

زيادة " لا

\section{تزاد "لا" عند النحاة في عدة مواضع، منها :}

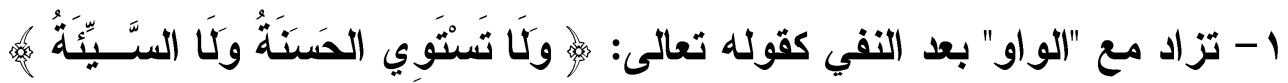

(ب)

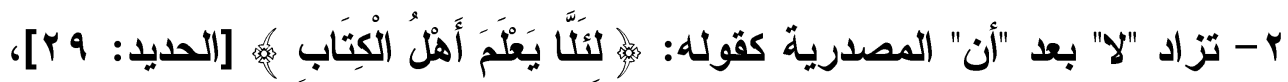

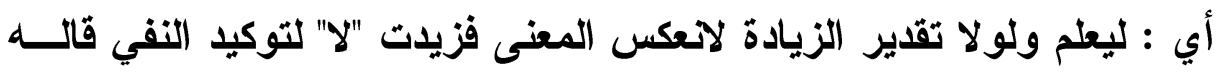
سيبويه وابن جني والشلوبين •

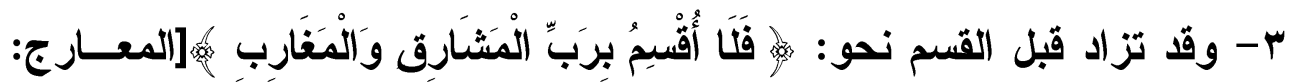

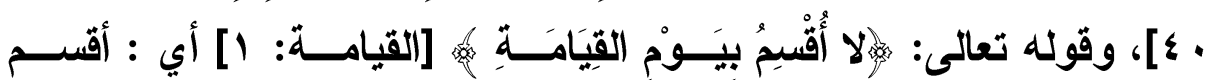

\section{بثبوتها.}

إلى غيرها من المواضع التي ذكرها النحاة، وأطلق الألوســي علــى "لا" الزائدة مصطلح "سيف خطيب"، وذلك في المواضع الآتية:

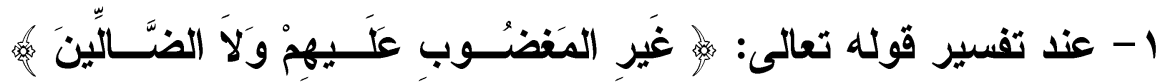
[الفاتحة: V]، قال الألمسي:" ورُوي عن عمر بن الخطاب - رضي الله تعالى عنه

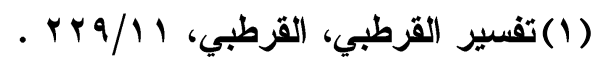

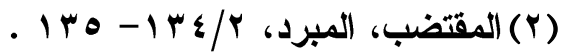




\section{الترقير الدولخ}

ISSN 2356-9050
क.
حولية كلية اللفة العربية بجرجا مجلة علمية محكمة العربية

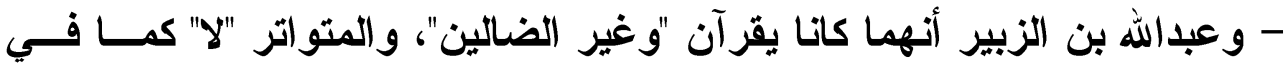
الإمام، وهو سيف خطيب أتى بها لتأكيد ما في "غير" من معنى النفي، والكوفيون

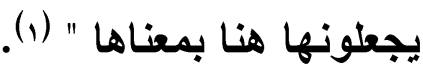

وقال الزجاج:" و إنما جاز أنْ يقع "لا" في قوله تعالى:" ولا الضــالين"؛ لأن

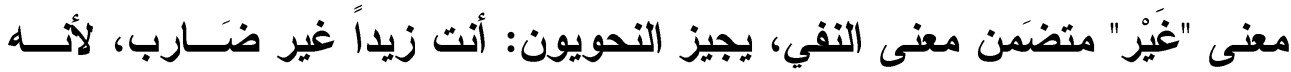
بمنزلة قولكك أنت زيداً لاَ تضربَ، ولا يجيزون أنت زيداً مثل ضارب، لأن زيدًا من صلة ضارب فلا يَتقَمَ عليه"(r).

r

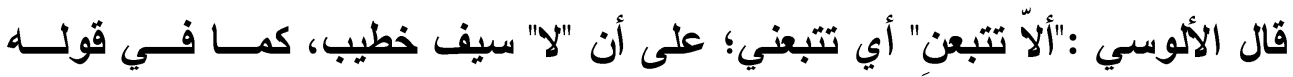

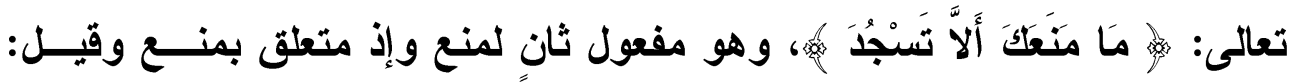

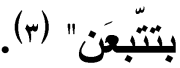

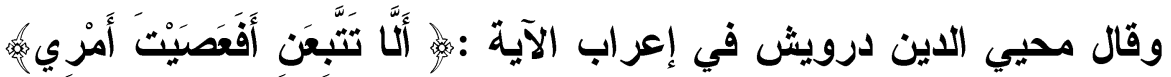

أن حرف مصدري ونصب، ولا مزيدة أي أي شيء منعك من اتباعي في الغضــب لله وهلا قاتلت من كفر بمن آمن، والهمزة للاستفهام الانكاري والفاء عاطفة على مقدر وعصيث فعل ماض وفاعل وأمري مفعول به" (ء).

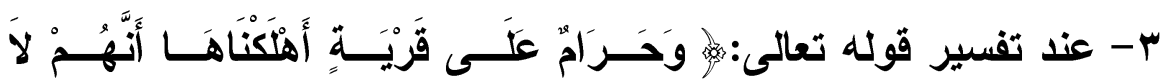

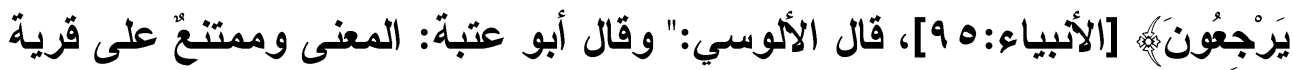

(1) روح المعاني، الألوسي، $97 / 1$ (1)

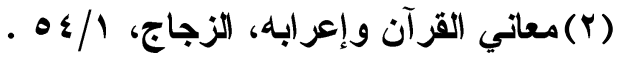

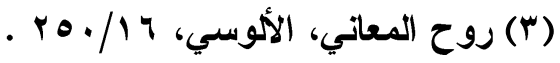

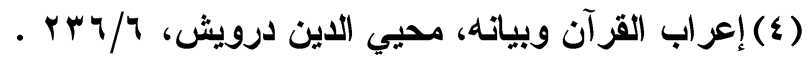


مصطلحات الزيادة

ودلالاتها عند الألوسي r.

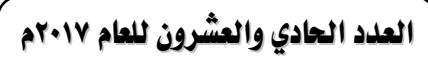

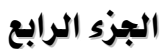

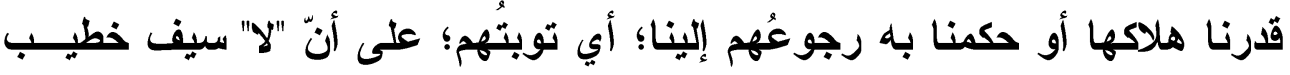

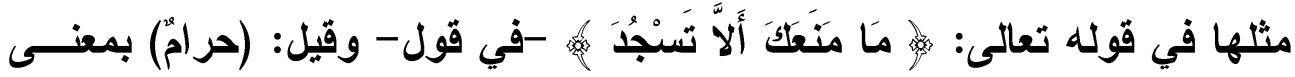

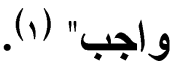

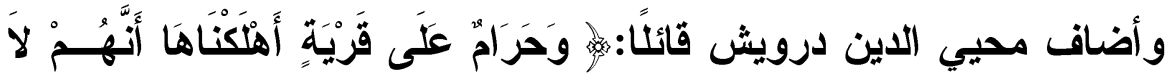

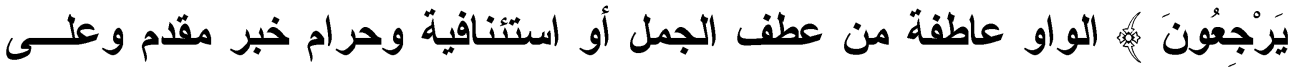

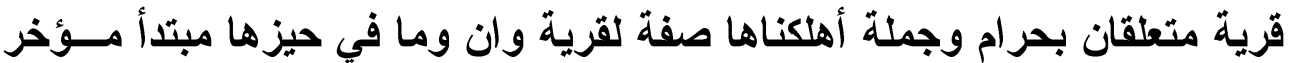
وأن واسمها وجملة لا يرجعون خبرها، وقيل لا زائدة، وهو قول أبي عبيدة كقوله

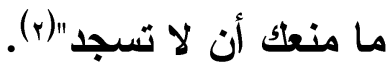

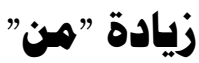

وتأتي "من" زائدة لتوكيد العموم، نحو: ما جاعني من أحد أو من ديّار (r). وأطلق الألوسي على "من" الزائدة مصطلح "سيف خطيب"، وذلك فــي المواضـــع

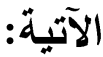

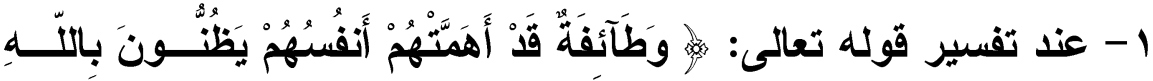

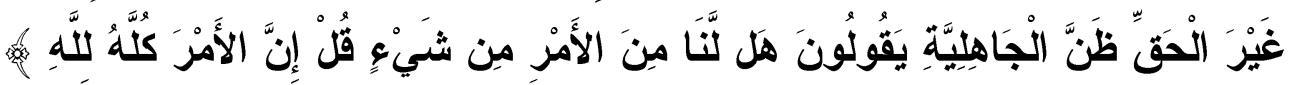

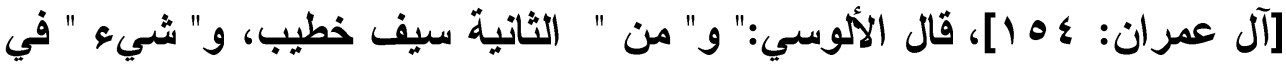
موضع رفع على الابتداء..." (ء).

(1) روح المعاني، الألوسي، $91 / 1 V$

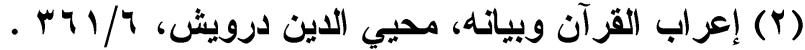

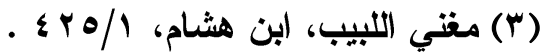

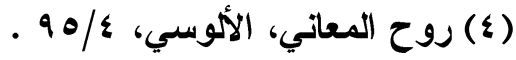




\section{الترقير الدولخ}

ISSN 2356-9050
Q

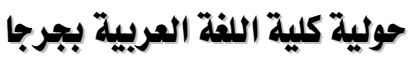

مجلة علمية محكمة

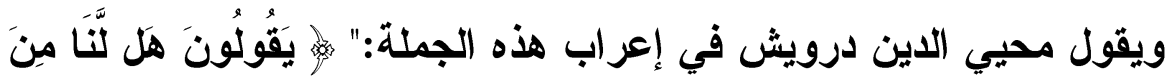

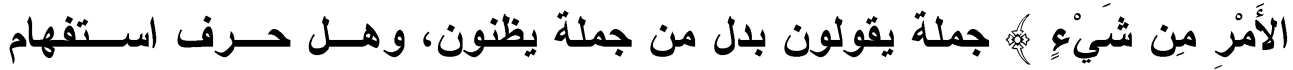

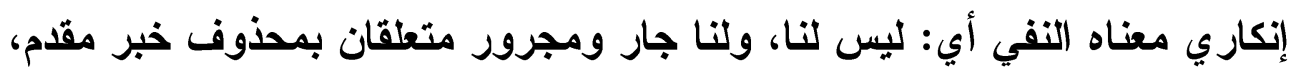
ومن الأمر جار ومجرور متعلقان بمحذوف حال؛ لأنه كان في الأصل صفة لشيء ثم تقدمت الصفة على الموصوف فأعربت حالا، ومن حرف جر زائـــ، وشــيء مجرور بمن لفظا في محل رفع مبتدأ مؤخر والجملة مقول القول"(1).

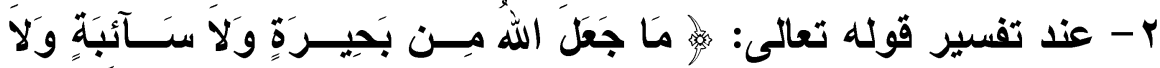

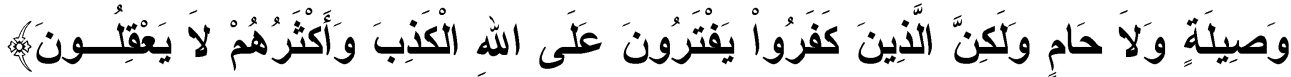
[المائدة: + ـ []، قال الألموسي:" ما جعل " ما شرع ولذلك عدي إلى مفعول واحــ وهو "بحيرة" وما عطف عليها، و "من" سيف خطيب(r) أُتِيَ بها لتأكيا النفي" (r).

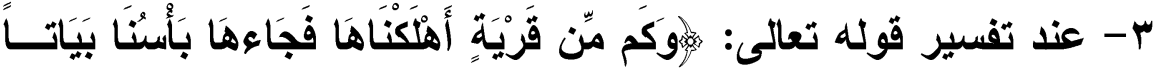

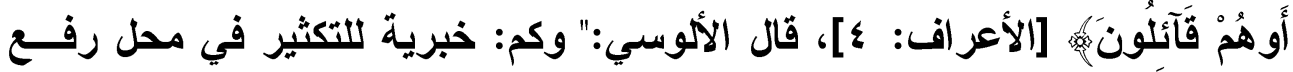
على الابتداء، والجملة بعدها خبرها، و "مِن" سيف خطيب، وقريةٍة: تمييز ويجــوز أن يكون محل كم نصباً على الاشتغال" (ء).

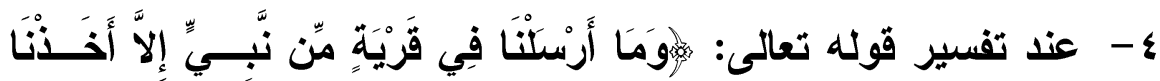

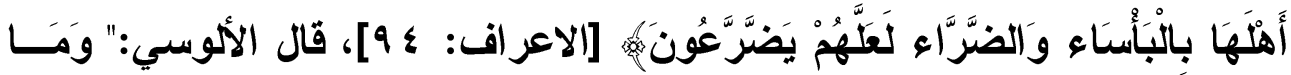

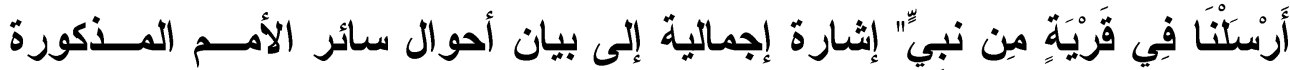

$$
\text { (1) إعراب القرآن وبيانه، محيي الاين درويش، VV/r ) }
$$

(Y) أي زائدة، وهذار رأي مجموعة من المعربين للقرآن الكريم. انظر : التبيان في إعراب

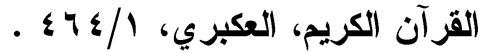

$$
\begin{aligned}
& \text { (T) روح المعاني، الألوسي، T/V ؛ ـ } \\
& \text { ( ) روح المعاني، الألوسي، (^: \^). }
\end{aligned}
$$



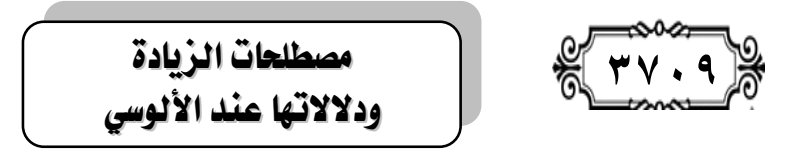

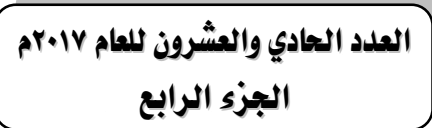

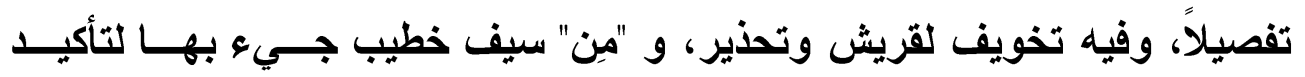

النفي" (1).

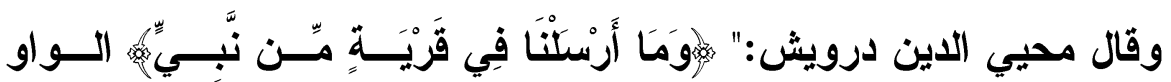

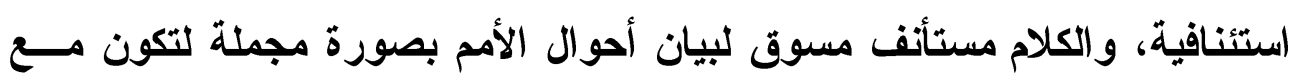
القصة نذيرا للمنذرين. وما نافية، وأرسلنا فعل وفاعل، ومن حرف جـر زائســا، ونبيّ مجرور لفظا منصوب محتّا على أنه مفعول به" (r).

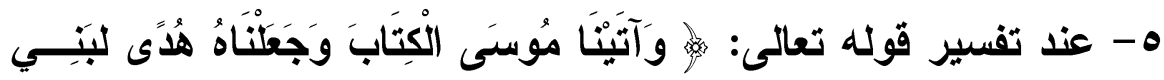

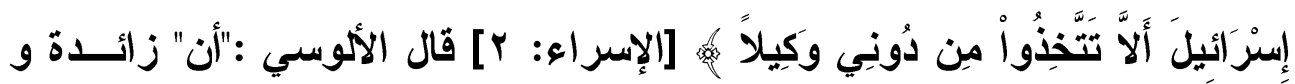

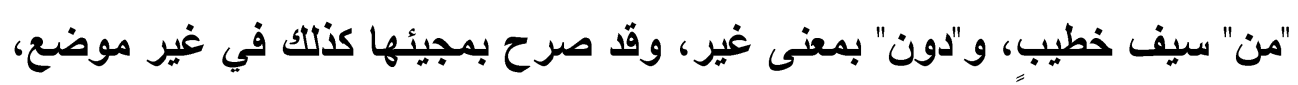

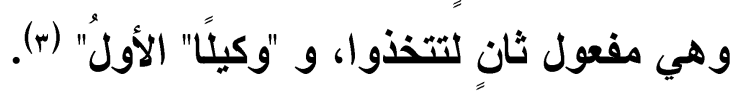

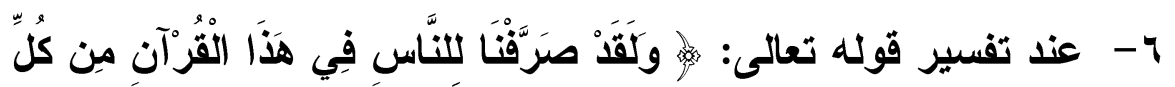

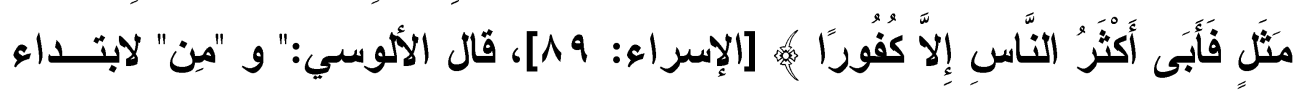

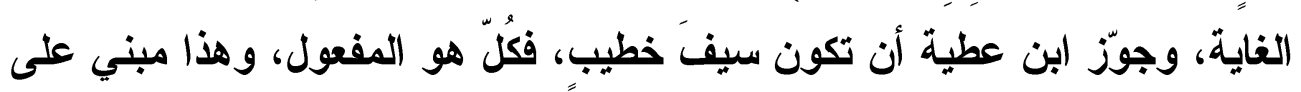

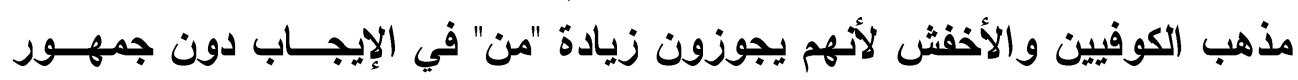

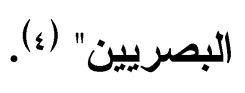

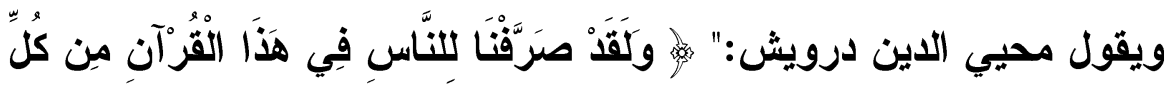

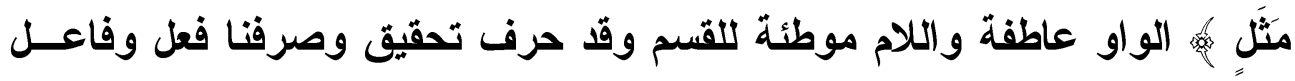

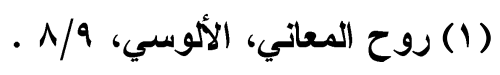

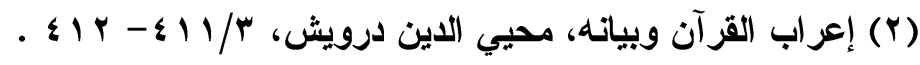

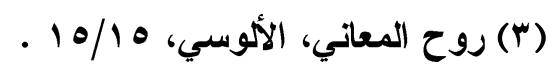

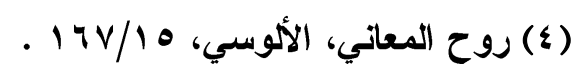




\section{الترقير الدولخ}

ISSN 2356-9050
T.

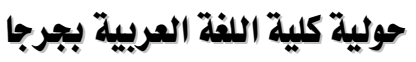
مجلة علمية محكمة المية

وفي هذا متعلقان بصرفنا والقرآن بلال ومن كل مثل صفة للمفعول به المدـذوف أي من كل معنى هو كالمثل في غرابته وحسنه"(1).

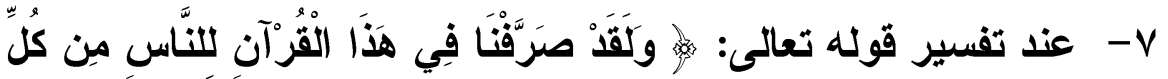

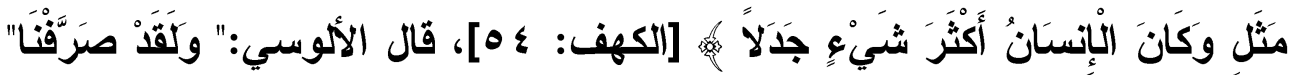

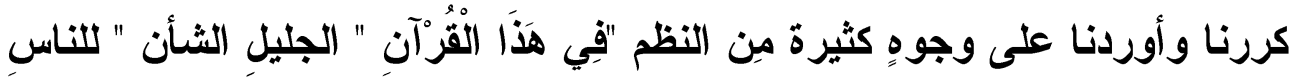

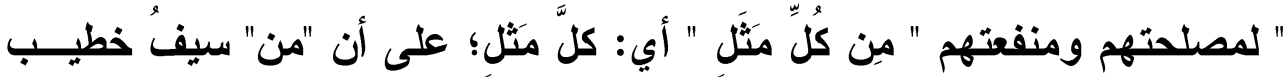

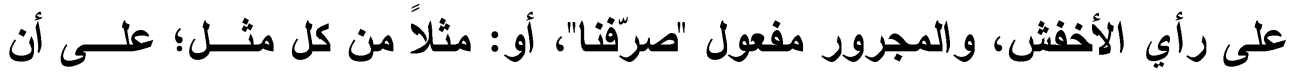
"هن" أصلية والمفعول موصوف الجار والمجرور المحذوف" (ץ).

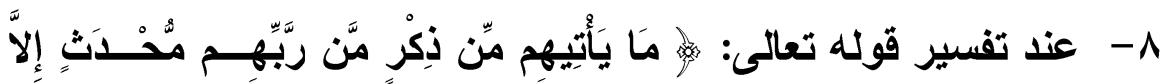

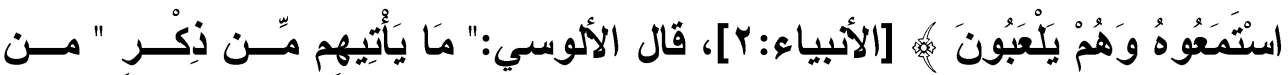

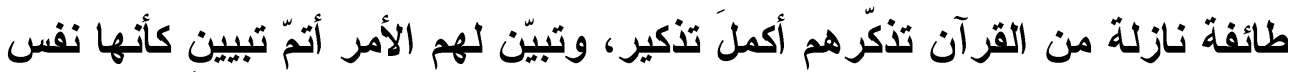

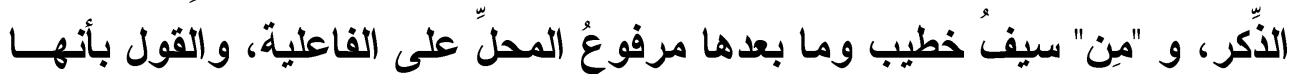

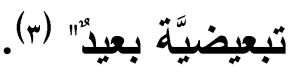

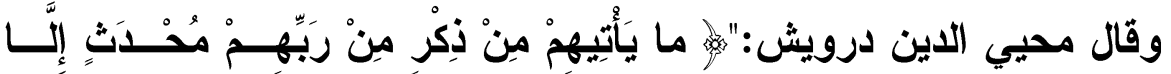

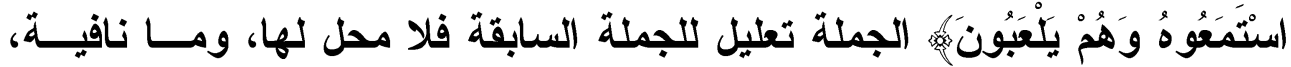
ويأتيهم فعل مضارع والهاء مفعول به ومن حرف جر زائد لسبقه بالنفي وذكــر مجرور لفظا مرفوع محلا على الفاعلية ومن ربهم صفة لــكر ومحســث صـفة

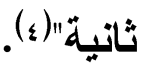

(1) إعراب القرآن وبياته، محيي الدين درويش، 9V/0 ؛ . (Y) روح المعاني، الألوسي، 0 (

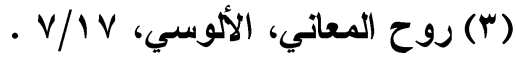

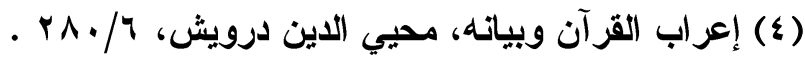



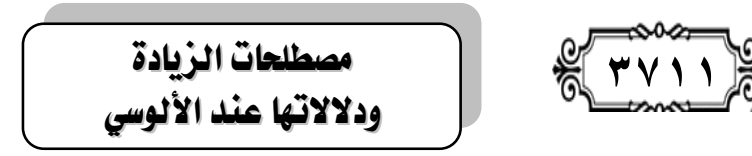
العدد الحادي والعشروز للعام VY.l

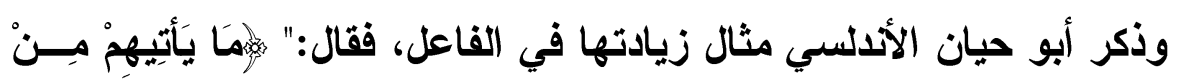

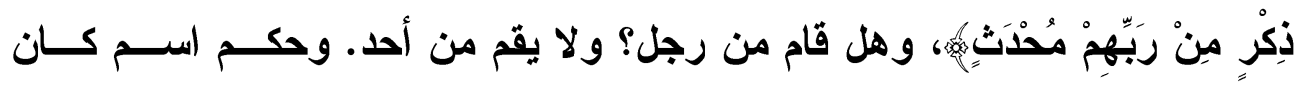

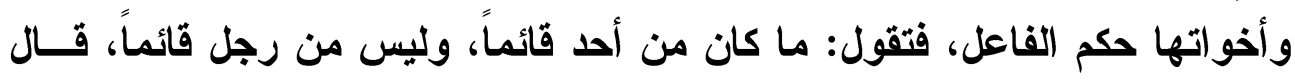

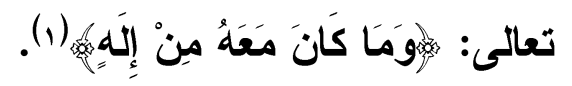

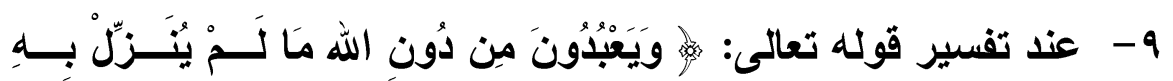

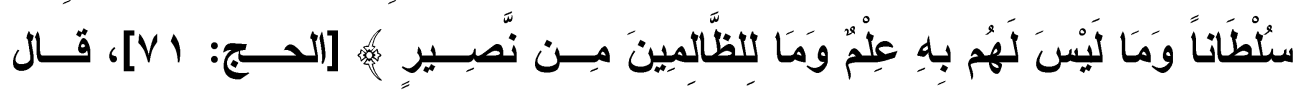

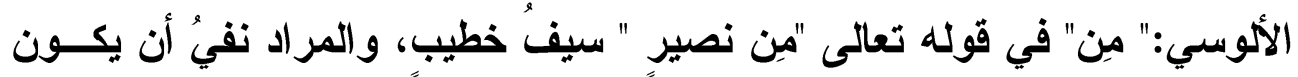

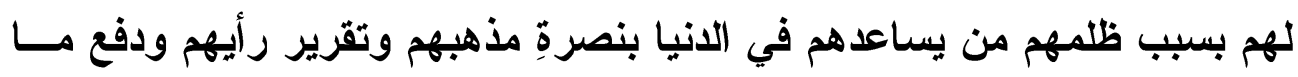
يخالفه، وفي الآخرة بدفع العذاب عنهم" (؟).

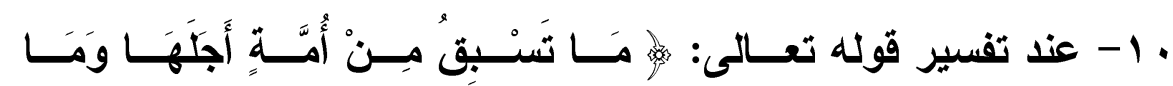

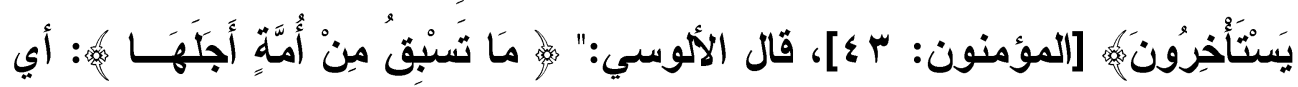

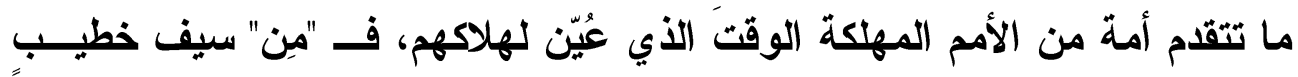

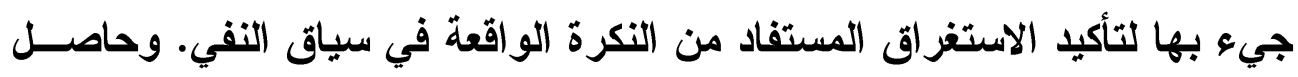
المعنى: ما تهلك أمة من الأمم قبل مجيء أجلها"(*).

وقال محيي الاين درويش في إعراب الآية السابقة:" ما نافية وتسبق فعل

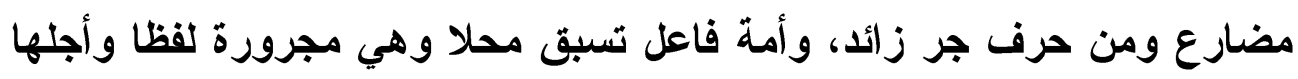
مفعول به وما يستأخرون عطف على مدا تسبق وحمل على ولى لفظ أمة أجلها فــأفرد

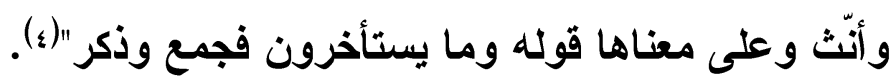

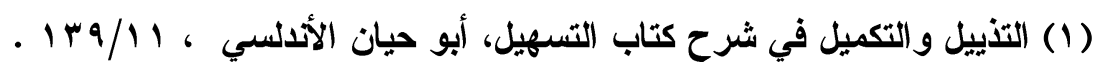

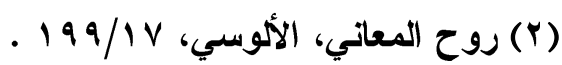

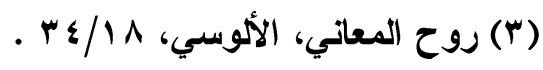

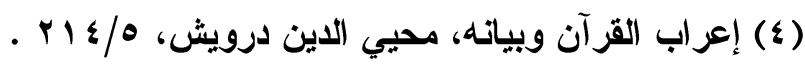




\section{الترقير الدولخ}

ISSN 2356-9050
Q
حولية كلية اللفة العربية بجرجا مجلة علمية محكمة

11

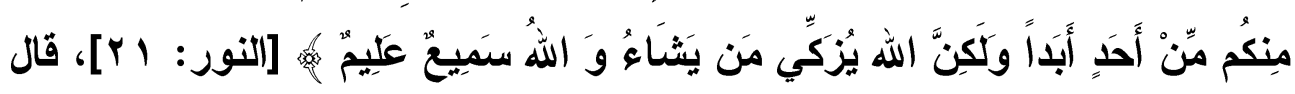
الألوسي:" مِن" في قوله تعالى: "منكم" بيانيّة، وفي قوله سبحانه :"مِن أحدٍ " سيف

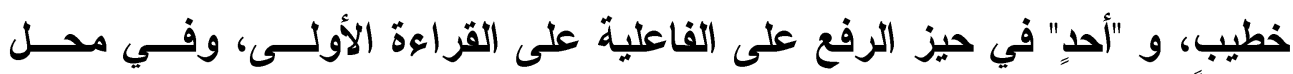
النصب على المفعولية على القراعة الثانية، والفاعل عليها ضميره تعالى أي مـــا زكى الله تعالى منكم أحدا " أبداً " (1).

وأضاف محيي الاين درويش: " ومن أحدٍ" ومن حرف جــر زائــــ وأحـــ مجرور لفظا منصوب محلا على أنه مفعول به(r).

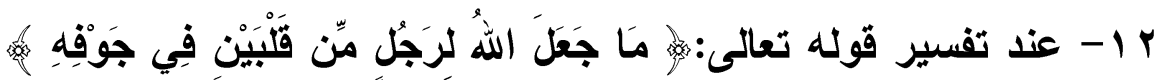

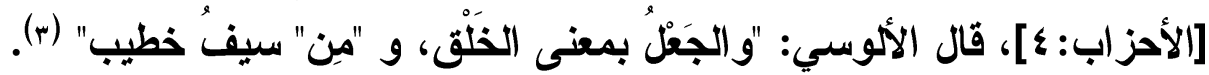

\section{زيادة الواو}

الواو الزائدة هي التي دخولها كخروجها، وقد أثبتها الكوفيون والأخفـش

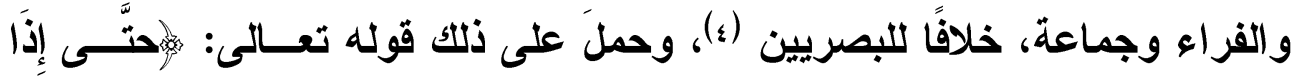

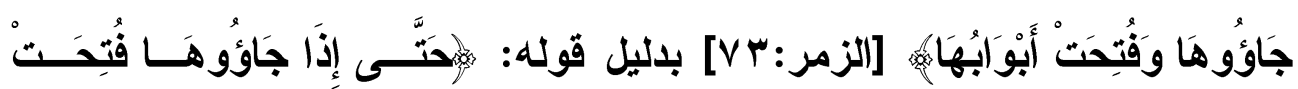

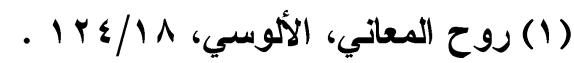

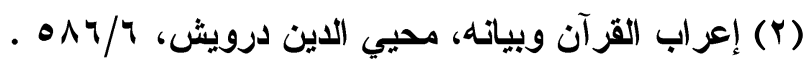

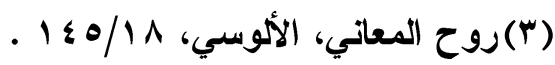

(ع) قال المبرد في المقتضب، 11/ م :" زيادة الواو غير جائزة عند البصريين". وانظر:

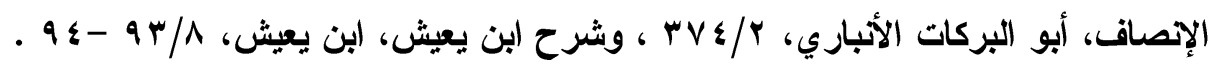



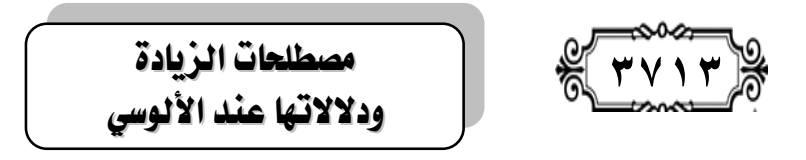

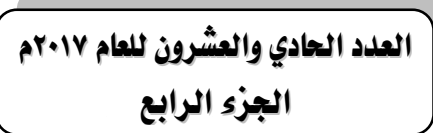

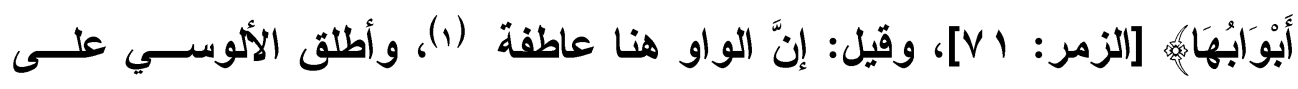
"الو او" الزائدة مصطلح "سيف خطيب"، وذلك في المواضع الآتية:

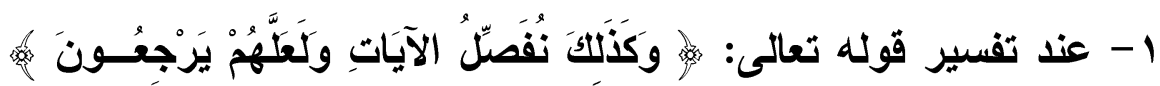

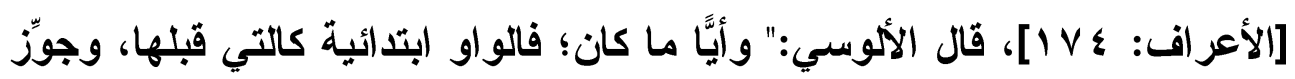

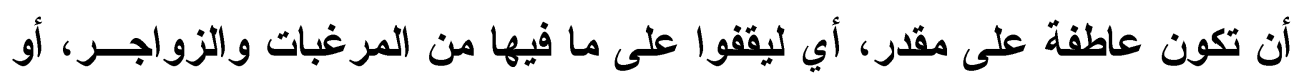
ليظهر الحق ولعلهم يرجعون، وقيل إنها سيف خطيب" (r).

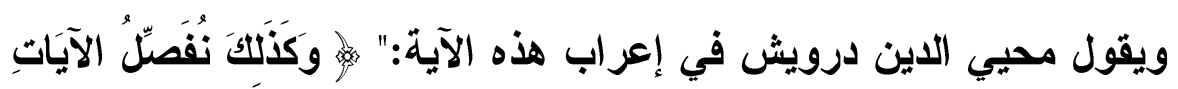

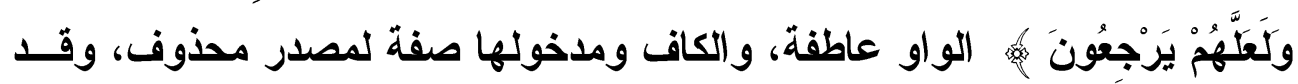

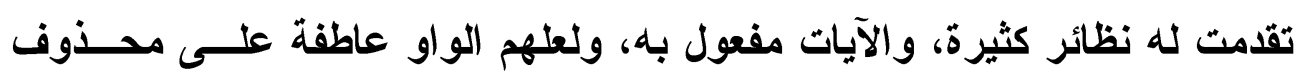

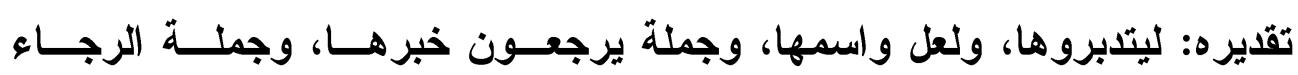
حالية"(r).

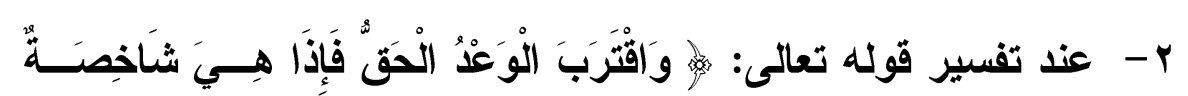

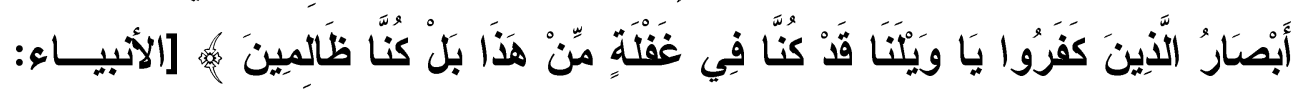

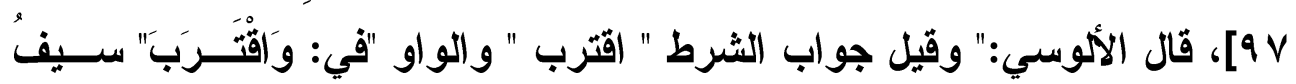

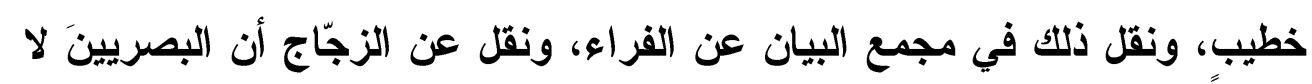

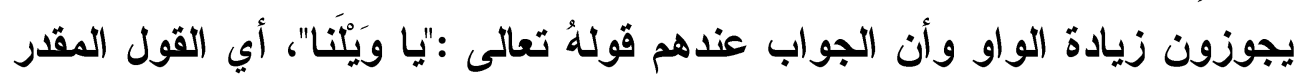
قبله؛ فإنه بتقدير : قالو إيا ويلناه (ء).

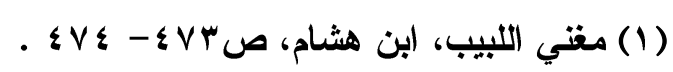

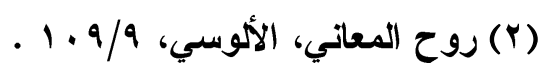

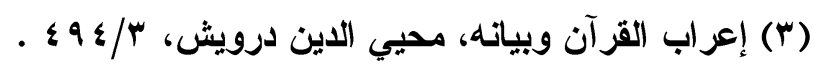

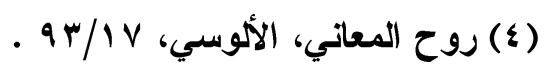




\section{الترقيم الدوله \\ ISSN 2356-9050}

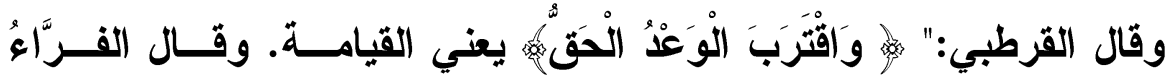

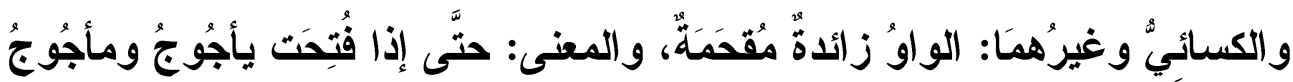

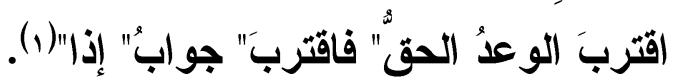

\section{زيادة "هـ"}

\section{تأتي "ما" زائدة في عدة مواضع :}

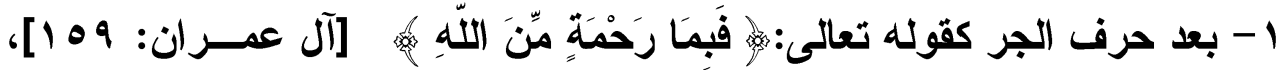

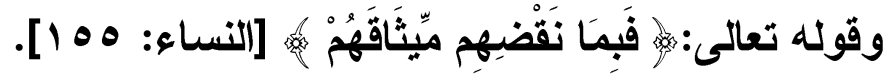

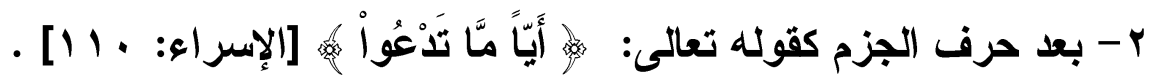

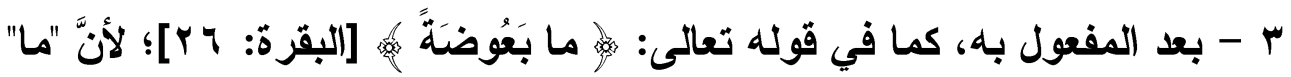
زائدة في الكلام، وإنما هو: إن الله لا يستحي أن يضرب بعوضة مثلاً (ب).

ع - تكون زائدة كافة عن عمل الرفع وذلك بعد قلَّ، و كثر، وطال (r) .

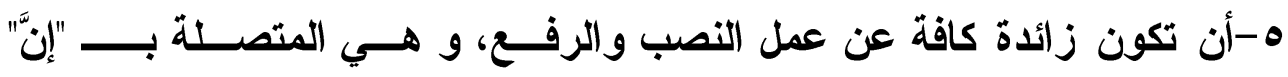

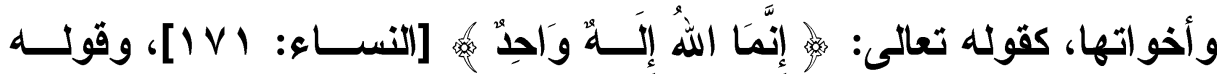

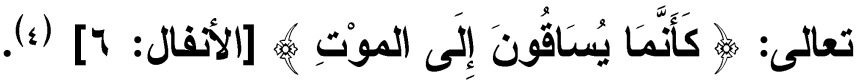

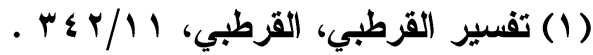

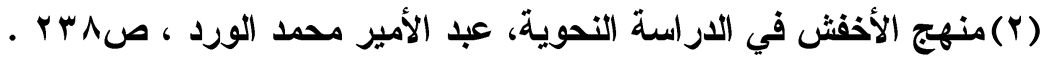
(T) مغني اللبيب، ابن هشام، T// ـ ـ .

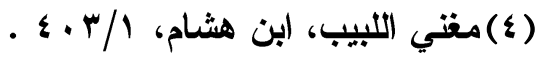

\section{0}




\section{مصطاحات الزيادة \\ ودلالاتها عند الألوسي}

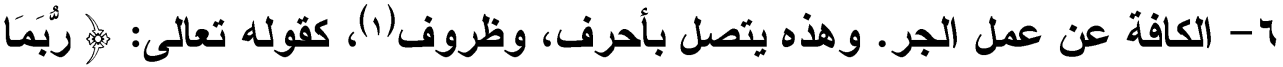

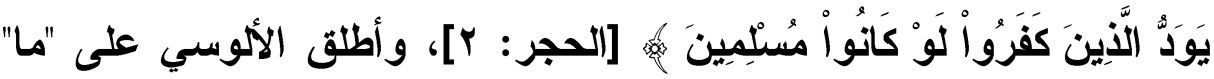
الزائدة مصطلح "سيف خطيب"، وذلك في المواضع الآتية:

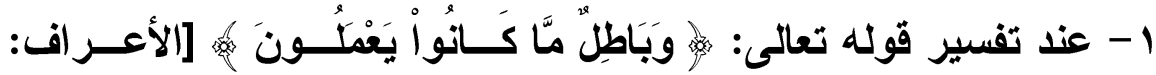
9 T I I]، قال الألموسي:" ما " مرتفعة به على الفاعلية وقرئ "وبطل" بصيغة الفعـل أي: ظهر بطلانه حيث علم هناك أن ذالك وما يستتبعه من الخطوط الدنيوية مما لا طائل تحته أو انقطع أثره الدنيوي فبطل مطلقًا، وقرأ أبي وابن مسعود "وبــاطلاً"

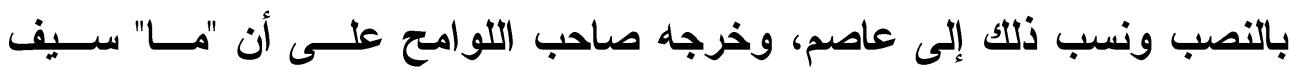
خطيب، و "باطل" مفعول لــ "يعلمون" وفيه تقديم معمول كان" (ץ).

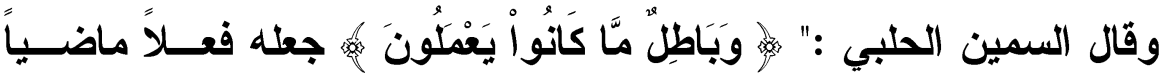

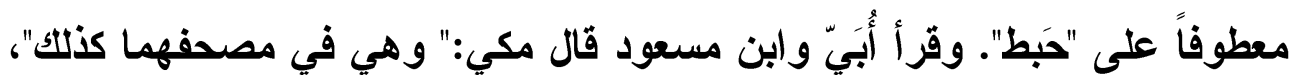

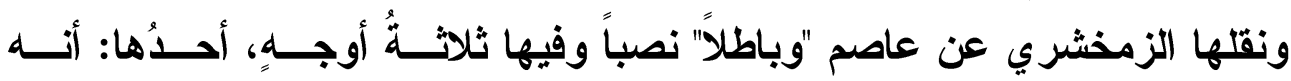
منصوبٌّ ب "يعملون" و "ما" مزيدة، وإلى هذا ذهب مكي وأبو البةـــاء وصـــاحب " اللوامح " ، وفيه تقديمُ معمول خبر "كان" على "كان" وهي مسألة خلاف"(؟).

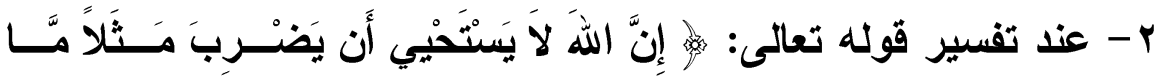

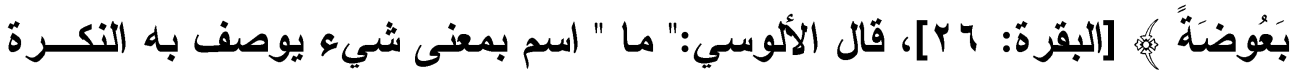

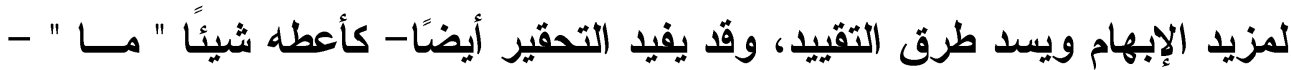
والتعظيم كـ - لأمر ما جدع قصير أنفه - والتنويع - كأضربه ضربًا " مــا " -

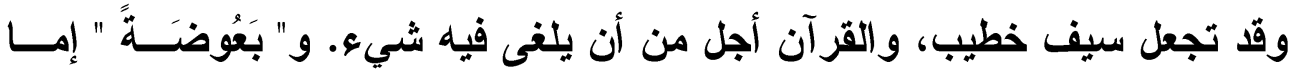

$$
\begin{aligned}
& \text { (1) مغني اللبيب، (بن هشام، V/ • ع - ـ 1 . } \\
& \text { (r) روح المعاني، الألوسي، r r r r . }
\end{aligned}
$$

(T) الار المصون في علوم الكتاب المكنون، السمين الحلبي، 


\section{الترقير الدولخ}

ISSN 2356-9050

صفة - لما -، أو بدل منها، أو عطف بيان إن قيل بجوازه في النكرات، أو بدل من " مثلا " أو عطف بيان له إن قيل " ما "زائدة أو مفعول" (1).

زيلادة اللام

وهي التلام الزائدة التي يسميها النحاة لام التقوية، وهي المزيلة لتقويــة

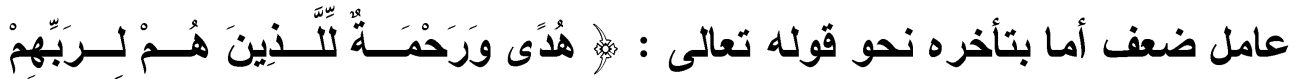

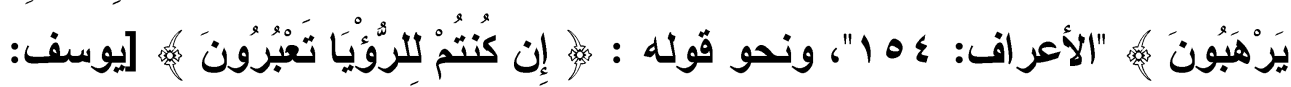

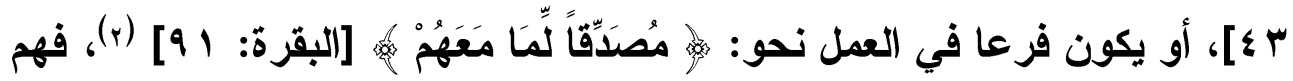

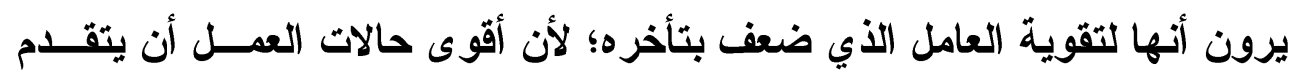
العامل، أو ضعف بكونه فرعًا لأنهم يرون أن الأصل أقوى من الفرع، كأن يكــون

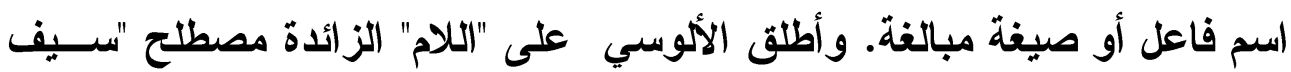
خطيب"، وذلك في المواضع الآتية:

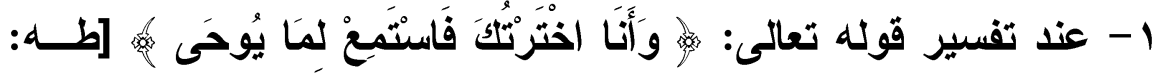

با 1]، قال الألوسي في إعرابه لحرف الكلام:" وقيل هي سيف خطيب فلا متعلق لها كما في "ردفَ لكم" وما موصولة...." (r).

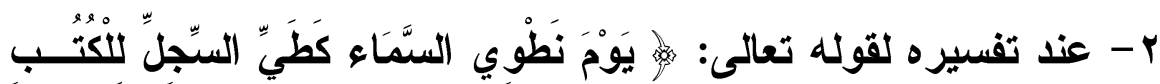

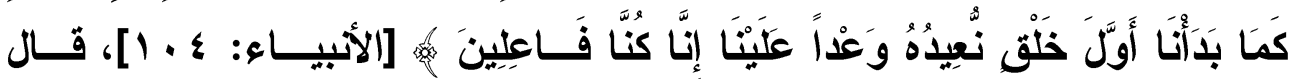
الألوسي:" واللام -على هذا - قيل متعلقة بطَيِّ، وقيل سيفُ خطيب" (ء).

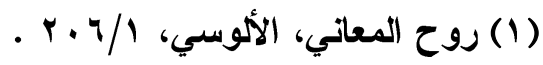
(Y) مغني اللبيب، ابن هشام، rAV- YVT/I

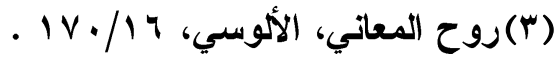

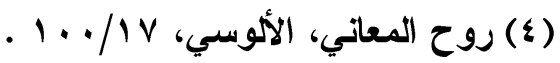



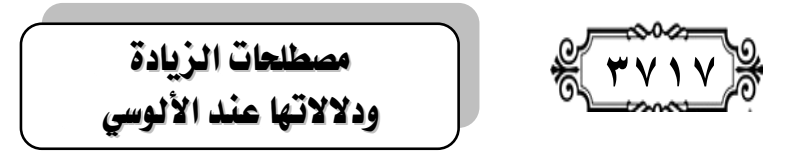

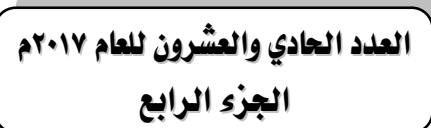

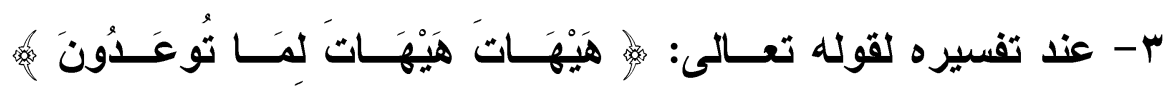

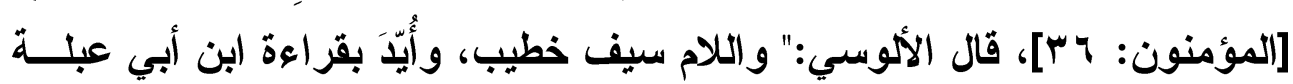

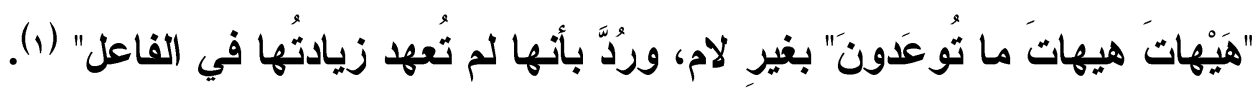

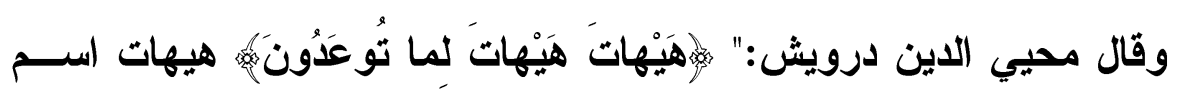

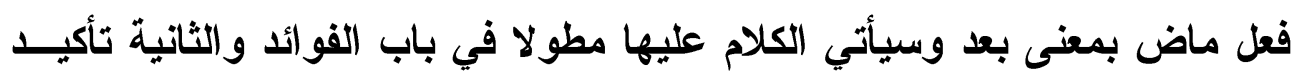

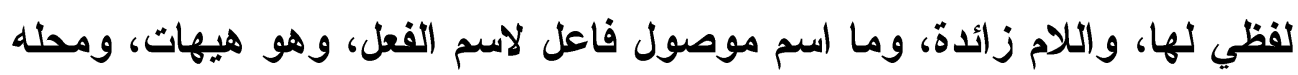

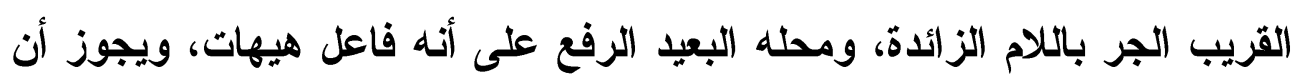
تكون ما مصدرية، والمصدر المؤول فاعل هيهات"(ץ).

\section{زيادة الفاء}

الفاء الزائدة هي التي دخولها في الكلام كخروجها، وهذا لا يثبته سيبويه،

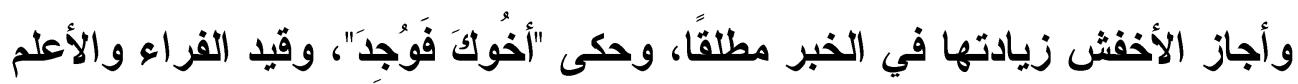

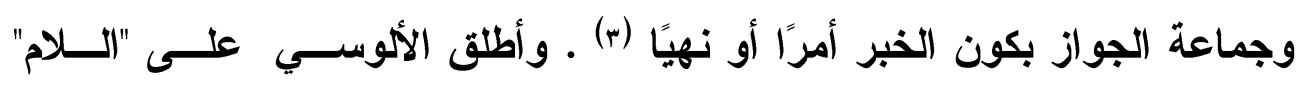
الزائدة مصطلح "سيف خطيب"، وذلك في الموضع الآتي:

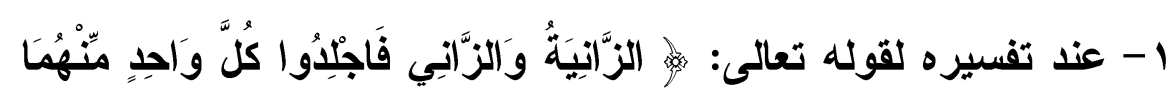

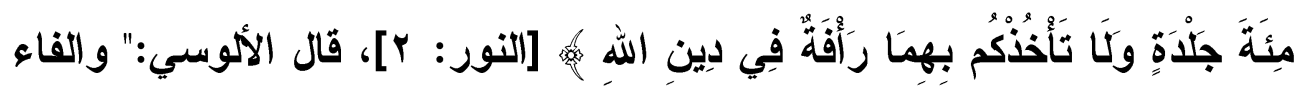

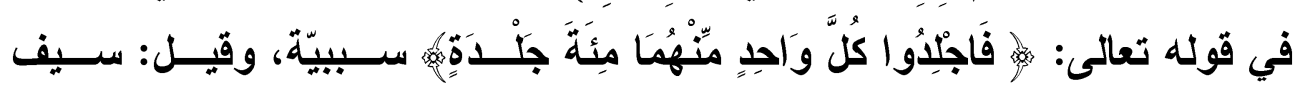

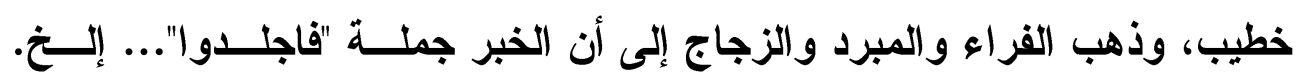

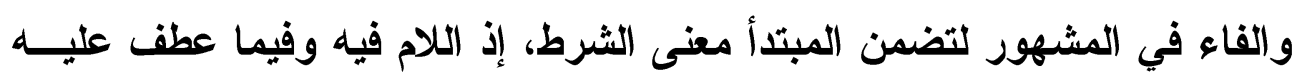

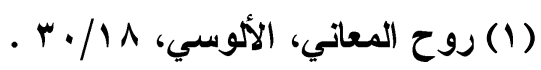

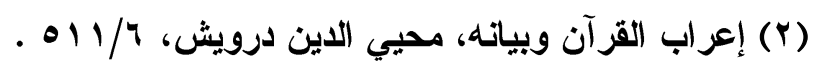

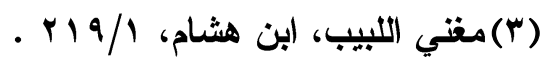




\section{الترقير الدول\$ \\ ISSN 2356-9050}

موصولة؛ أي التي زنت والأي زنى فاجلدوا.. إلخ. وبعضهم يجوز دخول الفاء في الخبر إذا كان في المبتدأ معنى يستحق به أن يترتب عليه الخبر وإن لم يكن هناك

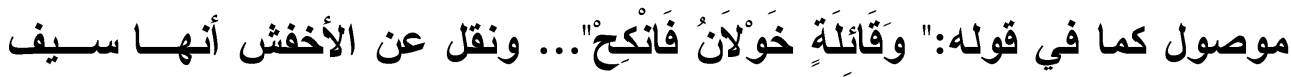

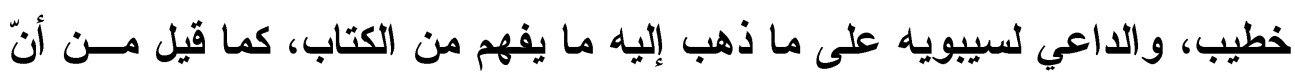

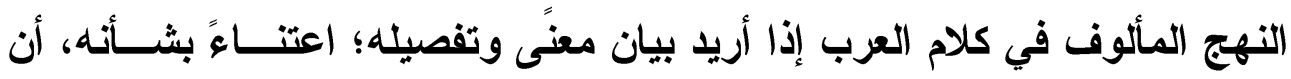
يذكر قبله ما هو عنوان وترجمة له وهذا لا يكون إلاّ بأن يبنى على جملتين؛ فما ذهب إليه في الآية أولى لذلك مما ذهب إليه غيره..." (1).

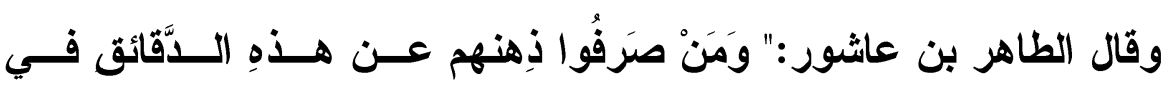

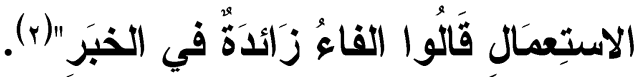




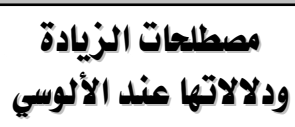

\section{ثانياً: هاشية الألوبسي على شرح القطر:}

زيادة "هما"

ذكر ابن هثام أن الفعل المضارع يُبنى على الفتح بشرط أن تباشره نون

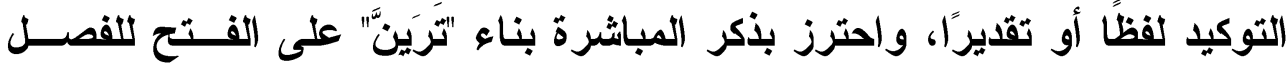
بالياء بين الفعل والنون.

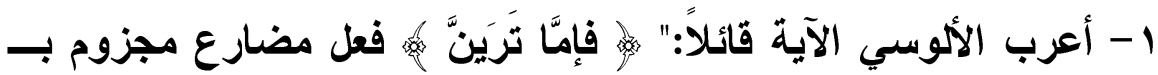

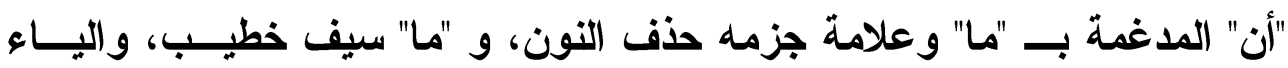
ضمير الفاعل، وأصله قبل التوكيد والثرط " ترأيين" نقلت حركة الهمزة إلى مــ قبلها وحذفت للساكنين، ثم دخل الجازم فحذف النون ثم أكّد وعمل به ما تقدّم" (1).

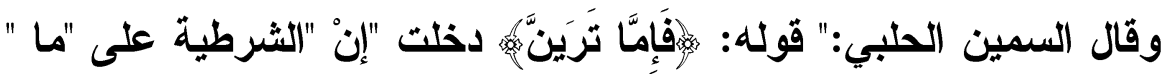

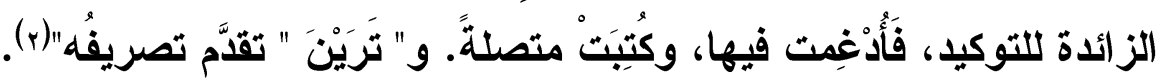

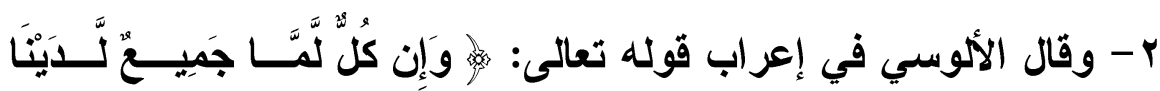

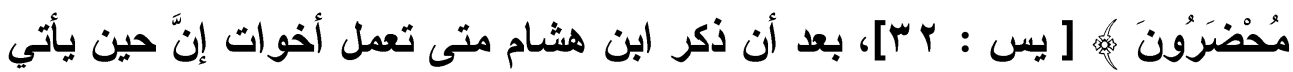

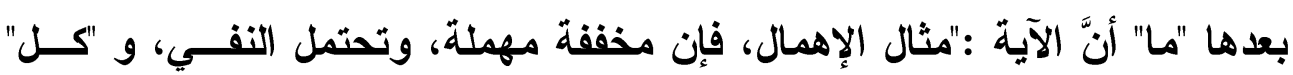
مبتدأ، واللام فارقة، و "ما" سيف خطيب...." (r).

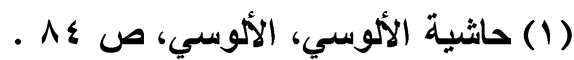

(Y) الار المصون في علوم الكتاب المكنون، السمين الحلبي، V/ •9ه ـ ـ

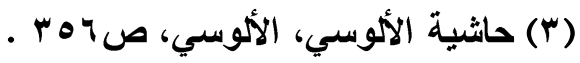




\section{الترقيم الدوله}

ISSN 2356-9050
T) PVY.
حولية كلية اللفة العربية بجرجا مجلة علمية محكمة

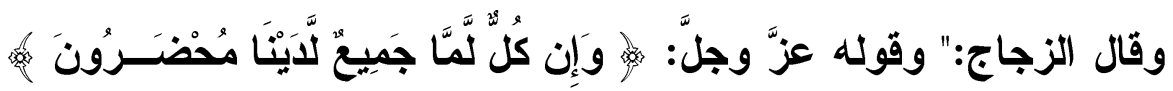
من قر أ بالتخفيف "لَمَا" فما زائدة مؤكدة، و المعنى إنْ كل لجميع لاينا مُحْضَــرُونَ،

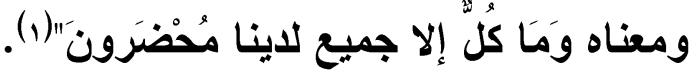

\section{زيادة الباء}

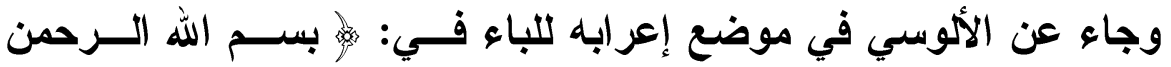

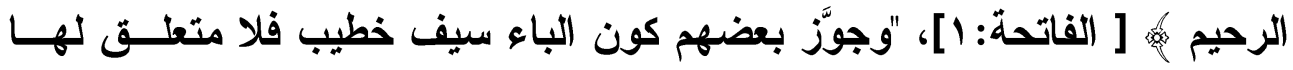

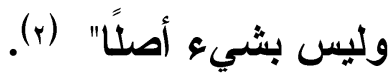

وقال النحاس:" والباء في بسم الله الرحمن الرحيم متعلقةٌ بشيء محذوفٍ

عند جميع النحويين، والتقدير عند البصريين: أول ما أفتتح به أو أول كلامي بسم الله الرحمن الرحيم، فالموضع موضع رفعٍ عندهم؛ وقال الفراء: موضـــع البــاء

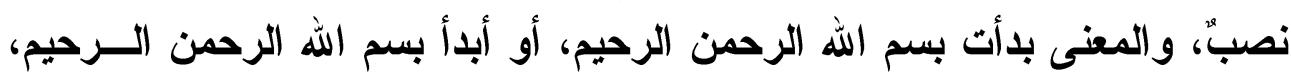
فحذف الفعل لأن المعنى يدل عليه"(r).

وقال محيي الاين درويش في إعراب هذه الآية : " بِسْمِ" جار ومجــرور

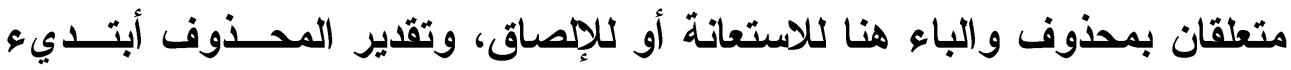
فالجار والمجرور في محل نصب مفعول به مقدم أو ابتدائي فالجــار والمجــرور متعلقان بمحذوف خبر لمبتدأ محذوف وكلاهما جيذ و" الله" مضاف اليه، و"الرََّّمن الرَّحِيمٍ" صفتان لله تعالى وجملة البسملة (بتدائية لا محلّ لها من الإعراب"(ع).

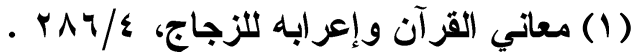

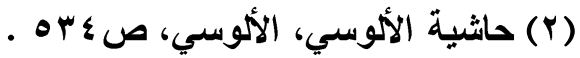

(r) عمدة الكتاب، أبو جعفر النحاس، صه7 .

( ) إعراب القرآن وبياته، محيي الدين درويش، 9 / . . 


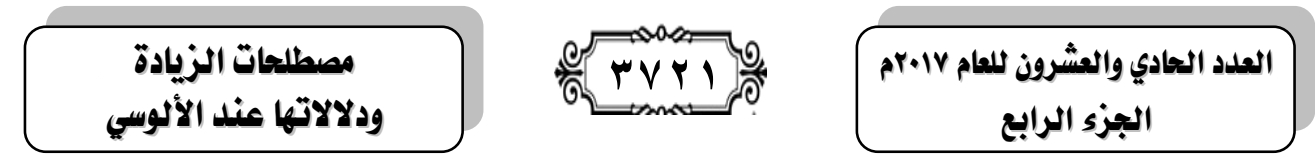

\section{دلالة حروف الزيادة عند الألوسي في "روح المعاني":}

لا يعني القول بالزيادة أنَّ في القرآن حشوًا - معاذ الله -، و إنما تحسوي

الجملة معنى إضافيَّا، وذهب أغلب النحاة إلى أن هذا المعنى هو توكيد الجملة.

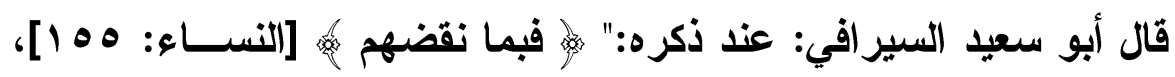

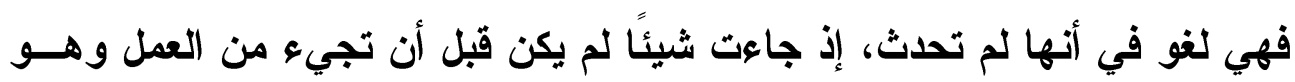

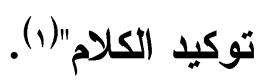

وقال الرضي:" قيل: إنما سميت زائدة؛ لأنها لا تتغير بها أصل المعنى، بل

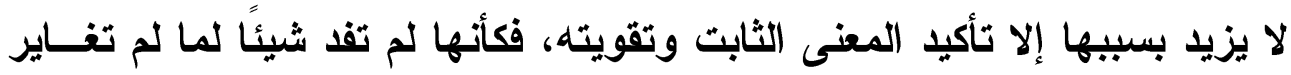

فائدته العارضة الفائدة الحاصلة قبلها" (r).

وقال محيي الدين الارويش:" فائدة الحرف الزائد في كــلام العـرب إمـــ

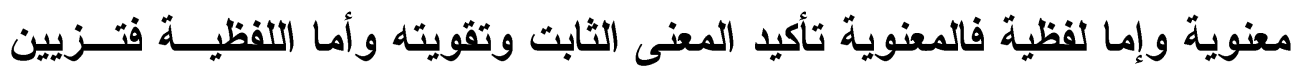

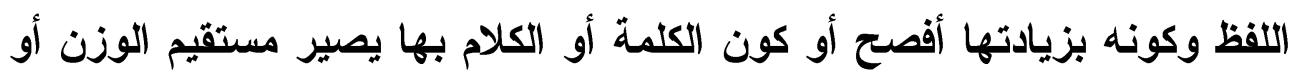

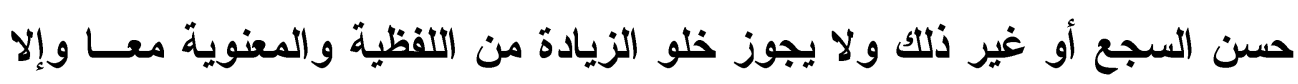

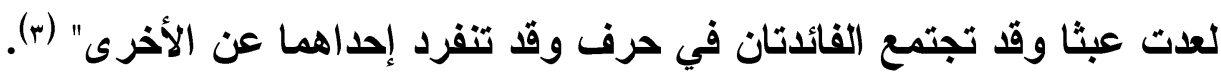

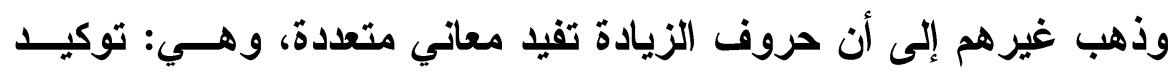

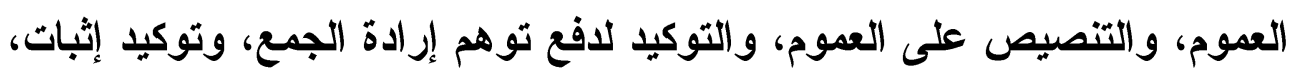

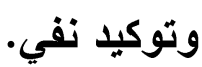

(1) (نظر : شرح كتاب سييويه، أبو سعيد السيرافي، 9V/0 .

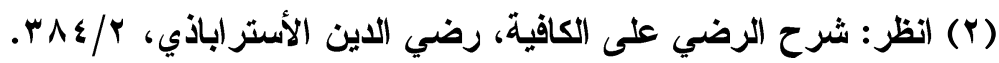

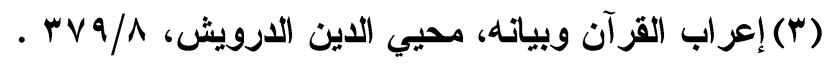

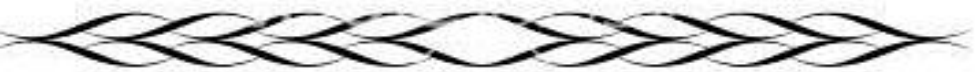




\section{الترقيم الدولم}

ISSN 2356-9050
Q
حولية كلية اللفة العربية بجرجا مجلة علمية محكمة

وذكر الألوسي في تفسيره أن "لكل حرف من كلام الله تعـالى فائـــة" (1)،

وحروف الزيادة قد تخرج عن المعاني التي وضعت لها فقال:" ويلتزم أن الزائد قد يدل على معنى غير التوكيد" (ץ)، وقال في موضع آخر في معرض حديثه عن "من" الزائدة:" وقد فهم أهل اللسان - كما قال الشهاب- أنها لتأكيد الاستغراق المفهــوم من النكرة المنفية لاختصاصها بذلك في الأكثر، وقد توقف محب الاين في وجـهـ

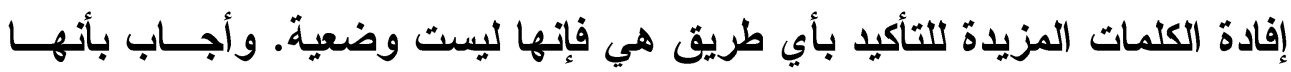

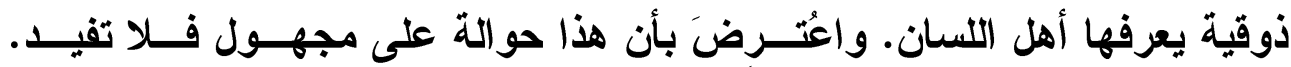
فالأولى أن يقال: إنها وضعية لكنه من باب الوضع النوعي فتدبر" (؟). وبيـنَّن د. تمام حسان أنَّ النحاة حددوا لكل جملة أركانًا ومكملات قياسية، بحيث يتم المعنى الوظيفي للجملة بوجود هذه العناصر، ولكن المعنى الموجود في

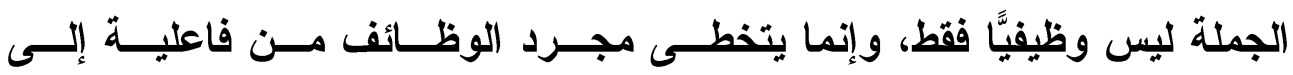

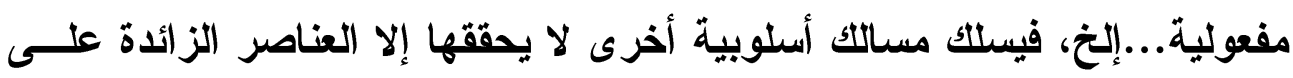
مجرد النمط التركيبي ذي المعنى الوظيفي، وإذا كان النحاة وصفوا هذه العناصــر بالزيادة فإن البلاغيين قالوا:" زيادة المبنى تدل على زيادة المعنى "، ويقصــدون بالزيادة في المعنى ما تحققه الجملة من توكيل وغيره جرَّاء الزيادة في المعنـى، فإذا قلنا:" ما زيد قائم" فقد استوفت الجملة أركانها وأداة أسلوبها، بحيث لا يفتقر تركيبها إلى شيء آخر، ولكن إذا أردنا توكيد نفي إسناد القيام إلــى زيــد، فــإنَّ وسيلتنا إلى ذلك أن نأتي بالحرف الزائد، فنقول: ما زيل بقائم (ء).

(1) روح المعاني، الألوسي، 1/ • ؛ .

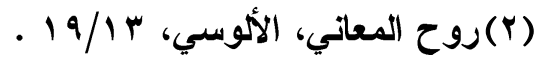

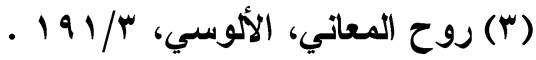

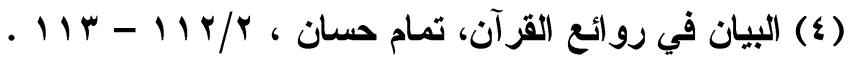




\section{مصطاحات الزيادة ودلالاتها عند الألوسي}

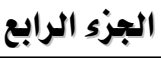

وقد أضاف الألوسي في تفسيره "روح المعاني" على مـــا سـبق بعـض

1- 1إفادتها السبيةية.

$$
\begin{aligned}
& \text { r-التوكيد. } \\
& \text { r-النفي } \\
& \text { ع-التبيه . } \\
& \text { ه-المبالغة . }
\end{aligned}
$$

צ-أن تكون زائدة بمعنى الحال.

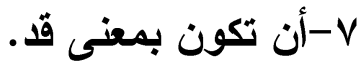

1-الزيادة لتضمنها معنى الشرط.

9-زائدة لتعدي الفعل بنفسه.

ـ أأن تكون زائدة داخله على التمبيز.

11 - 1 -دلالتها على معنى الأمر.

r ا الالالة على لزوم ما بعدها لما قباهها:

س ا -حذف الحرف الزائد يؤدي إلى اختلال المعنى.

وهذه أمثلة لذلك من تفسيره "روح المعاني". 


\section{الترقيم الدولخ}

ISSN 2356-9050
PVor

حولية كلية اللفة العربية بجرجا

مجلة علمية مجكمة

أولاً: إفادة السببية:

فقد ذكر الألوسي أن "الفاء" الزائدة قد تفيد السببية، وذلك عند تفسير قوله تعالى

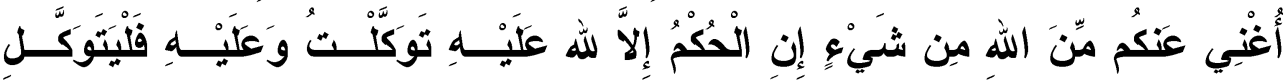

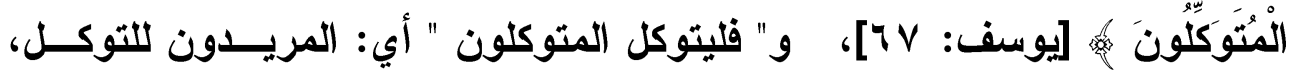
قيل: جمع بين الواو والفاع في عطف الجملة على الجملـــة مـــع تقــــيم الصــلـة للاختصاص ليفيد بالواو عطف فعل غيره من تخصيص التوكل بالله تعالى شــأنه

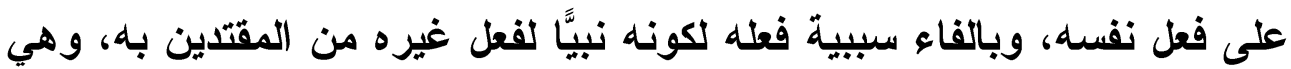
على ما صرح به بعضهم زائدة حيث قال: ولا بلَّ من القول بزيادة الفاء و إفادتهــا

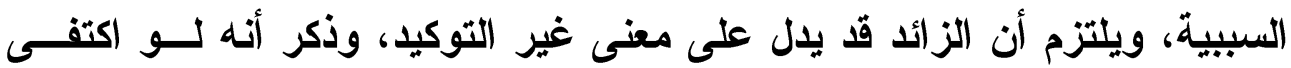
بالفاء وحدها وقيل: فعليه فليتوكل ... إلخ. أفاد تسبب الاختصاص لا أصل التوكل و هو المقصود، وكلّ ذلك لا يخلو من بحث. واختار بعضهم أنه جيء بالفاء إفادة

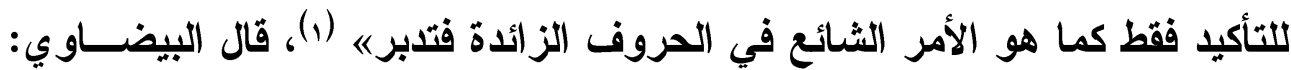
والفاء لإفادة التسبب فإن فعل الأببياء سبب لأن يقتدي بهم (ץ).

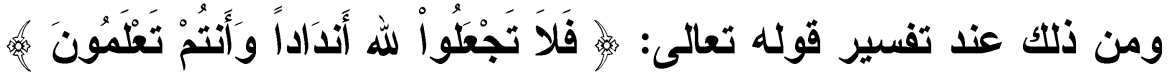

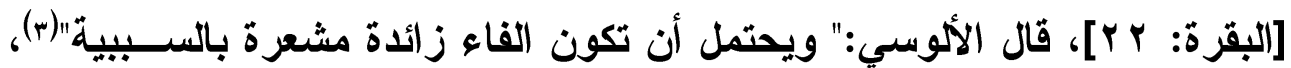
قال أبو السعود :" والفاء للإشعار بعليّة ما قبلها من الصفات المجراة عليه تعالى

(1) روح المعاني، الألوسي، بـ/1 19

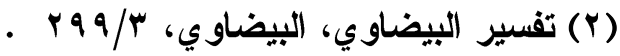

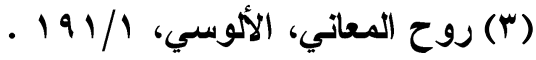




\section{مصطاحات الزيادة \\ ودلالاتها عند الألوسي}

\section{MVYO}

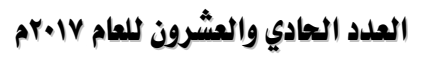

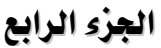

للنهى أو الاتتهاء..." (1)، وذكر السمين الحلبي أنَّها :" للتسبُبُ، أي تَنَسبَّبَ عـن إيجاد هذه الآيات الباهرة النهيُ عن اتخاذ الأداد" (ץ).

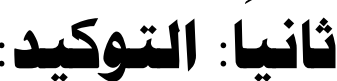

وهذا هو الأصل في معاني حروف الزيادة، وما ذكره أغلـب العلمــاء أن فائدة الزيادة هي توكيد المعنى، وقد ذكر الألوسي في تفسيره هذا المعنسى فئسي

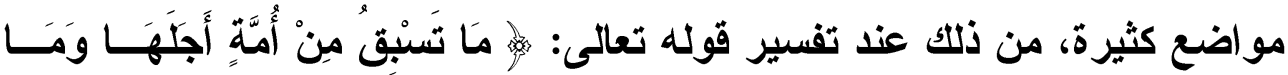

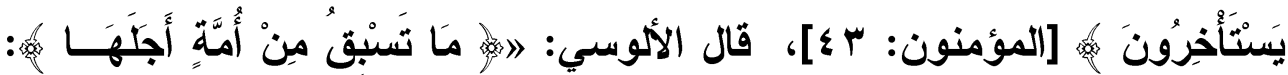

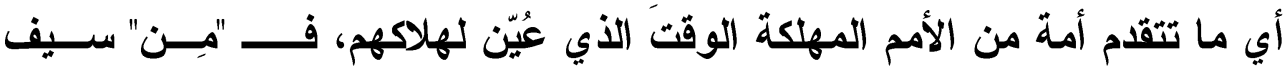
خطيب جيء بها لتأكيد الاستغراق المستفاد من النكرة الواقعة في سياق النفــي.

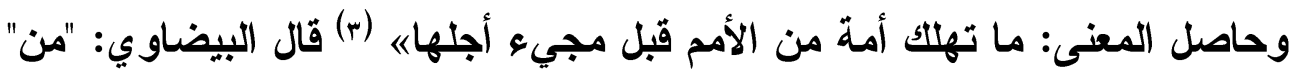

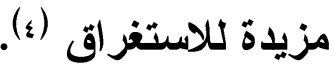

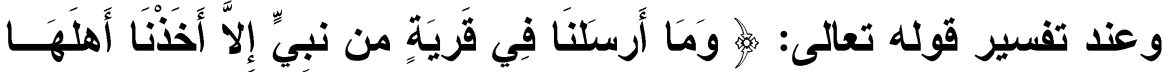

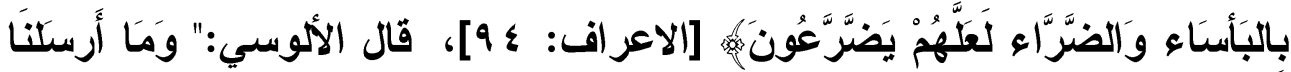

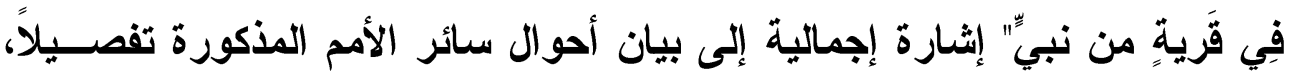

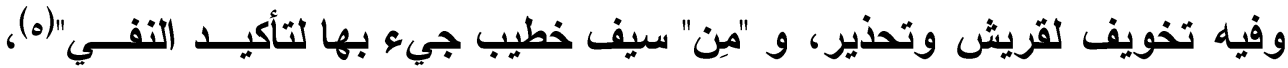
وقال أبو السعود: و "من" مزيدة لتأكيد النفي والصفة مذوفة أي من نبي كذب أو

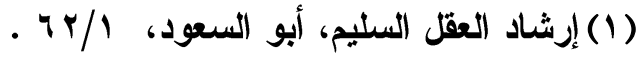

(Y) الار المصون، السمين الحلبي، / / 9 ا ـ

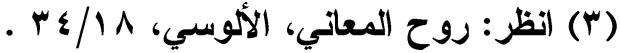

( ) انظر : تفسير البيضاوي، البيضاوي، \&/100 . (0) انظر : روح المعاني، الألوسي، 1/9 ـ ـ 


\section{الترقير الدولخ \\ ISSN 2356-9050}

كذبــه أهلــها (1)، وجاء في التفسير الكبير: فيه حذف وإضمار والتقدير من نبي فكذب أو كذبه أهلها إلا أخذنا أهلها بالبأساء والضراء(ץ)، وقال السيوطي: قال ابن حيان ويظهر من كلام سيبويه أن "من" هنا لتأكيد البيان فهي زائدة (؟).

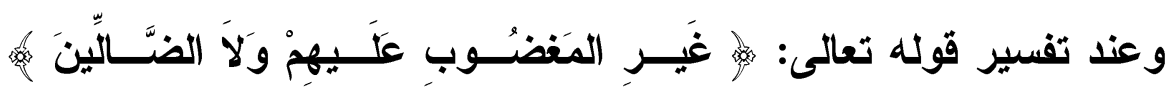
[الفاتحة: V]، قال الألوسي:" ورُوِيَ عن عمر بن الخطاب - رضي الله تعالى عنه

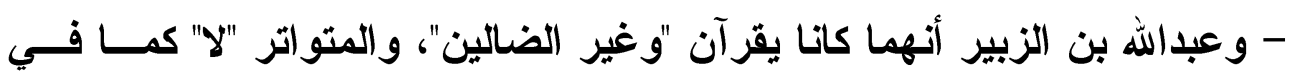

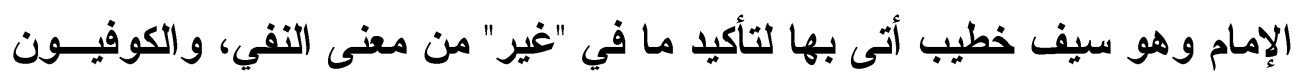

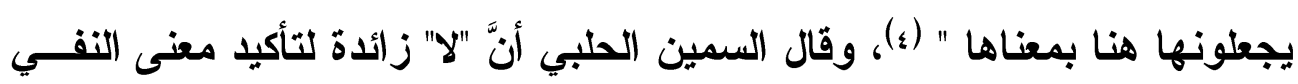
المفهوم من "غير" لئلا يُتَوَهَّم عطف "الضالين" على "(لأين أنعمث"، قال الكوفيــون

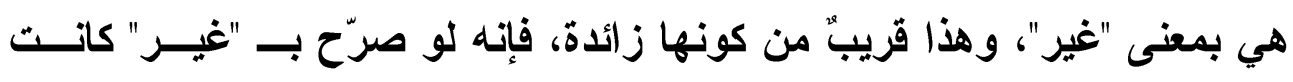
للتأكيد أيضًا (ه)، وقال العكبري:" لا" زائدة، عند البصريين للتوكيد، وعند الكوفين الكوفيين هي بمعنى "غير" كما قالوا: جئت بلا شيء فأدخلوا عليها حـــف الجــر فيكون لها حكم " غير"، وأجاب البصريون عن هذا بأن "لا" دخلت للمعنى فتخطاها العامل كما يتخطى الألف والتلام (،).

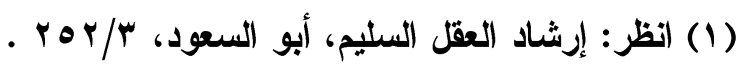

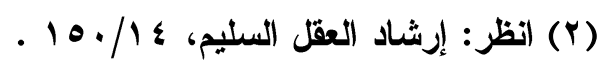

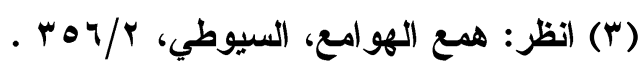

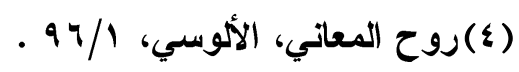

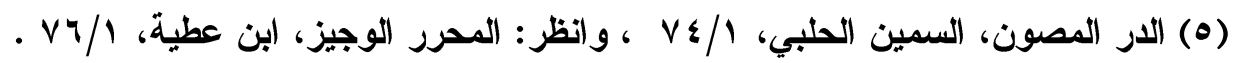
(7) التبيان في إعراب القرآن، العكبري، 9/1 .

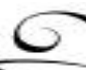



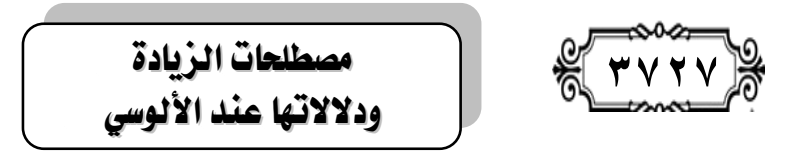

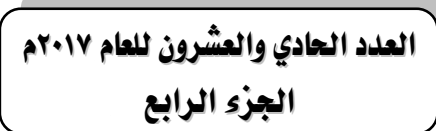

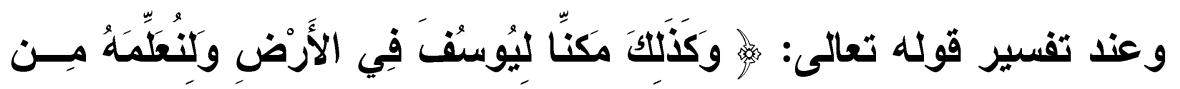

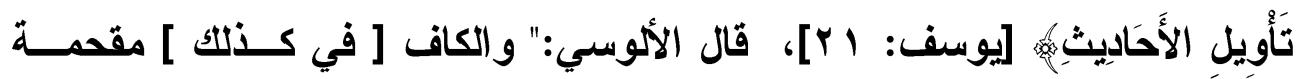

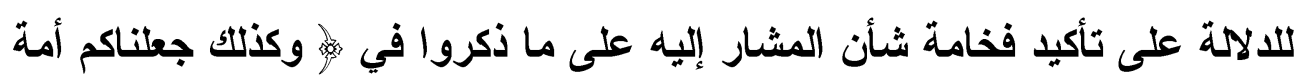

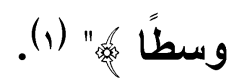

\section{ثالثًا: النفي:}

فقد ذكر الألوسي في تفسيره أن من معاني الزيادة النفي، ومن ذلك عنــــ

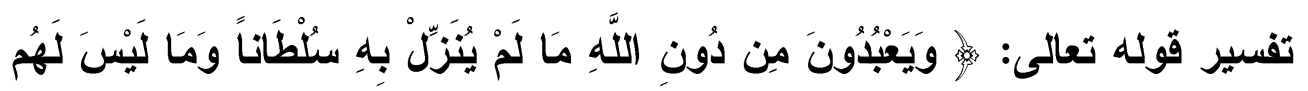

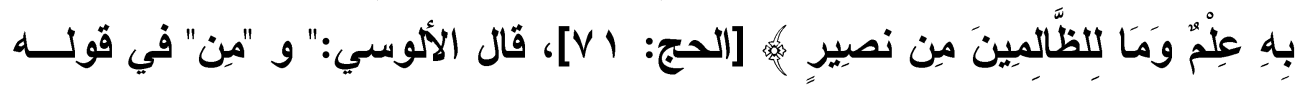

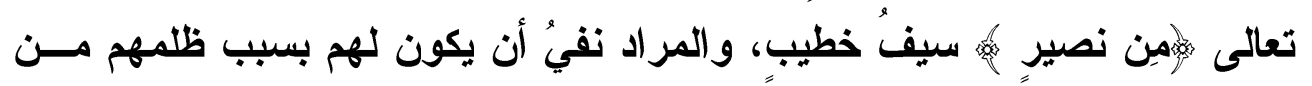

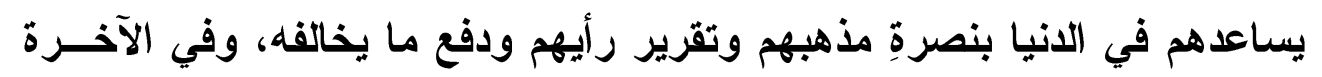

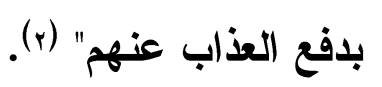

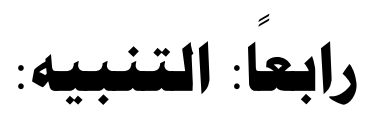

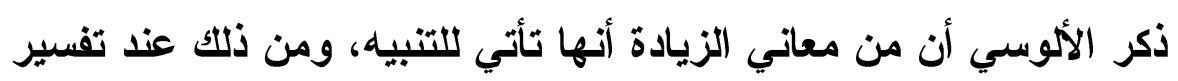

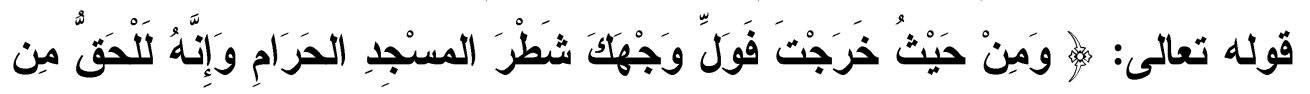

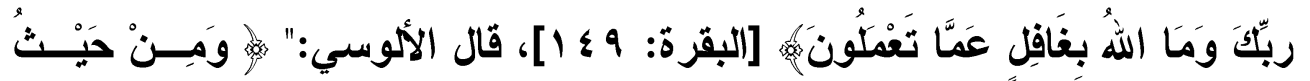

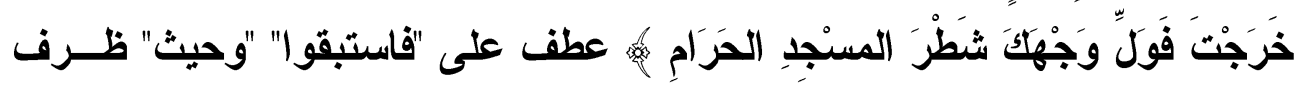

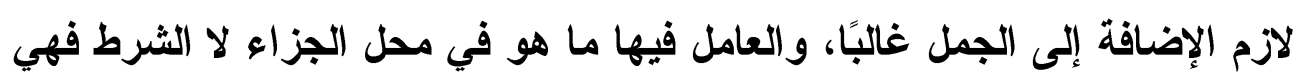

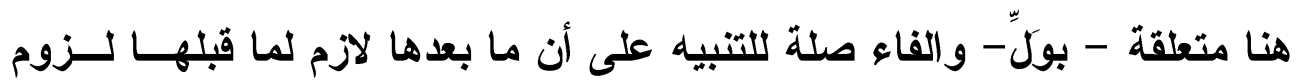

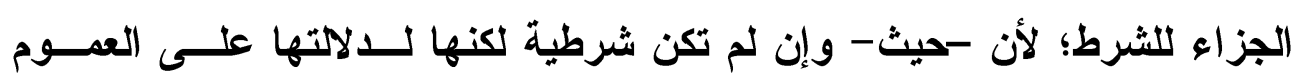

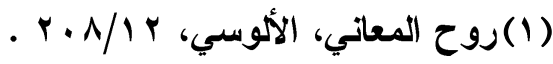

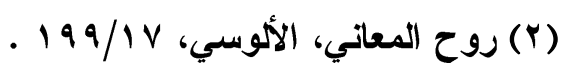




\section{الترقيم الدولخ}

ISSN 2356-9050

أثبهت كلمات الثرط فقيها رائحة الشرط، ولا يجوز تعلقها بــ"خرجت" لفظًا، وإن كانت ظرفًا له معنى لئلا يلزم عدم الإضافة. و المعنى من أي موضع خرجت فــول

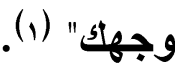

غاونسا: البالهنة:

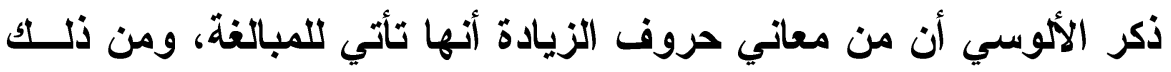

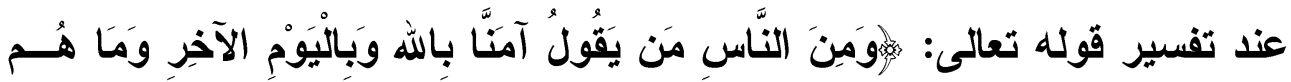

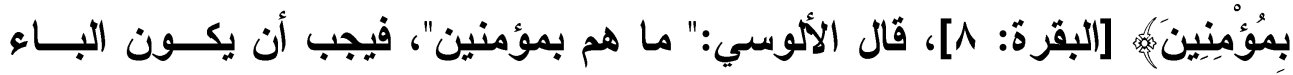

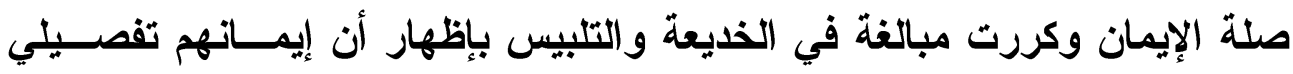
مؤكد قوي"(ץ)، وقال الزمخشري:" وفيه من التوكيد والمبالغة ما ليس في غيــره وهو إخراج ذواتهم وأنفسهم من أن تكون طائفة من طوائف المؤمنين لما علم من

حالهم المنافية لحال الاخلين في الإيمان" (؟).

\section{سادسا: أن تكون بمهنى الهمال :}

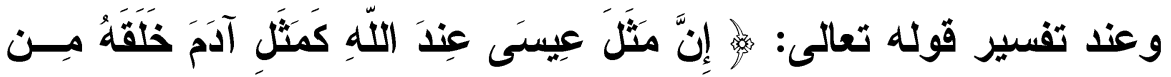

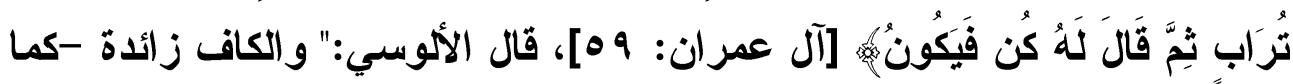
قيل به - بل بمعنى الحال" (ء)، قال أبو السعود:" كحاله العجيبة التي لا يرتاب فيها

(1) روح المعاني، الألوسي، 19/1 .

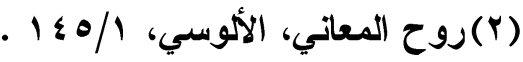

(r) الكثاف، الزمخشري، / 9 (T) .

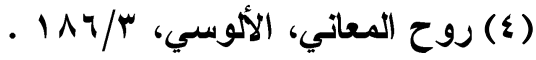




\section{مصطلحات الزيادة ودلالاتها عند الألوسي}

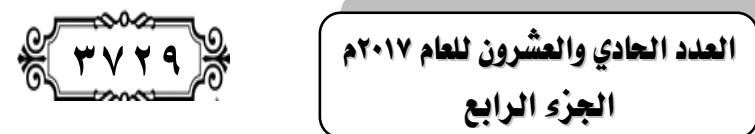

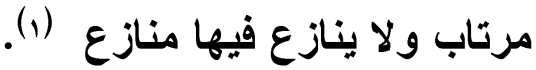

\section{سابعا: الدلالة على همنى الأهمر:}

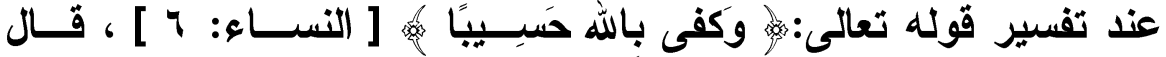
الألوسي : " والباء زائدة دخلت لتلال على معنى الأمر ، فالتقدير : اكتفـــوا بــالله تعالى" (ץ).

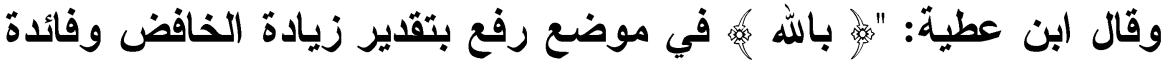

زيادته تبيين معنى الأمر في لفظ الخبر أي اكتفوا بالله فالباء تلدل على المراد" (م).

\section{ثاهنـا: بمهنى قد:}

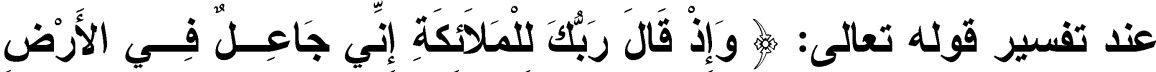

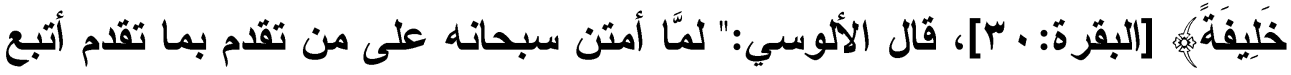
ذلك بنعمة عامة وكرامة تامة والإحسان إلى الأصل إحسان إلى الفرع و اللولا سر

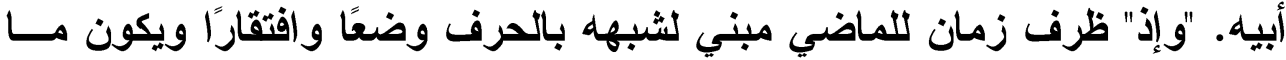
بعدها جملة فعلية أو اسمية، ويستفاد الزمان منها بأن يكون ثاني جزأيها فعلاً أو يكون مضمونها مشهورًا بالوقوع في الزمان المعين، وإذا دخلت على المضــارع قلبته إلى الماضي وهي ملازمة للظرفية إلا أن يضاف إليها زمان، وفي وقوعهـا مفعولا به أو حرف تعليل أو مفاجأة أو ظرف مكان أو زائدة خلاف، وفي البحسر الهـر إنها لا تقع، وإذا استفيد شيء من ذلك فمن المقام، واختلف المعربون فيها هنــا

$$
\text { (1) إرشاد العقل السليم، أبو السعود، ب/ه ؛ . }
$$$$
\text { (Y) روح المعاني، الألوسي، /9/ 19؛ . }
$$

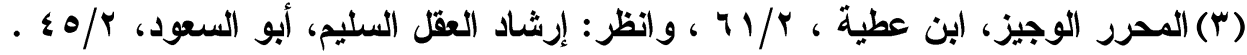

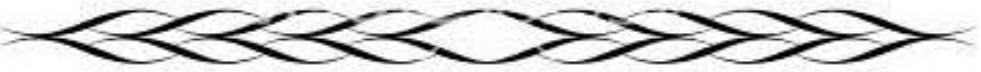




\section{الترقيم الدوله}

ISSN 2356-9050
Q. حولية كلية اللفة العربية بجرجا مجلة علمية محكمة

فقيل: زائدة وبمعنى قد، وفي موضع رفع أي ابتداء خلقكم إذ، وفي موضع نصب بمقدر أي - ابتدأ خلقكم أو أحياكم إذ - ويعتبر وقتاً ممتدًا لا حين القول، ويقال: بعدها ومعمول - لخلقكم- المتقدم والواو زائدة والفصل بما يكاد أن يكون سورة، ومتعلق -باذكر - ويكفي في صحة الظرفية ظرف المفعول - كرميث الصيد فـي الحرم - وهذه عدة أقوال بعضها غير صحيع والبعض الآخر فيه تكــف..." (1)، وجاء في أضواء البيان: "و "إذ" زائدة، وقيل معناه واذكر إذ قال ربك وكذلك كل ما ورد في القرآن من هذا النحو فهذا سبيله " (ب).

\section{تاسما: هتصنهنة همنى الششرط:}

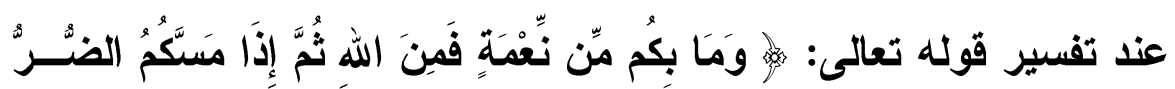

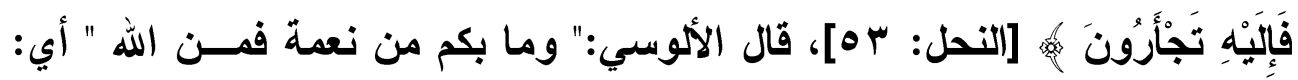

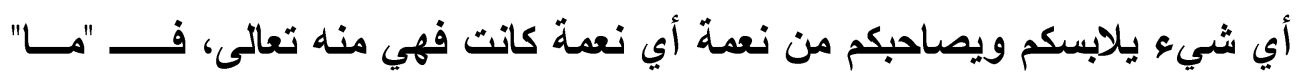
موصولة مبتدأ متضمنة معنى الشرط، و "من الله" خبرها، والفاء زائدة في الخبر

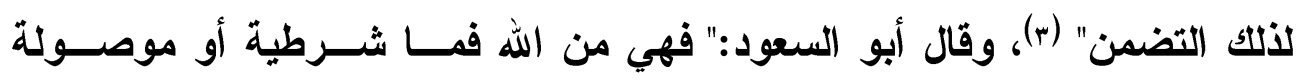
متضمنة لمعنى الشرط باعتبار الأخبار دون الحصول فإن ملابسة النعمة بهم سبب

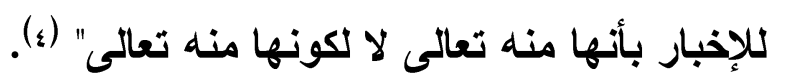

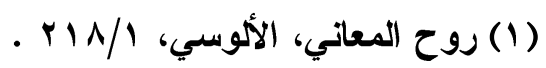

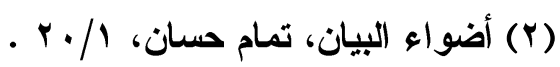

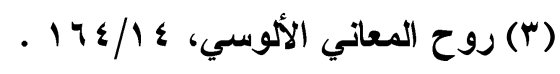

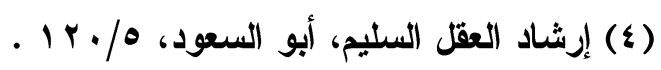

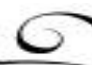


مصطلحات الزيادة

ودلالاتها عند الألوسي
की

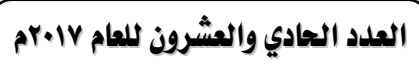

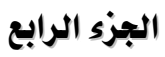

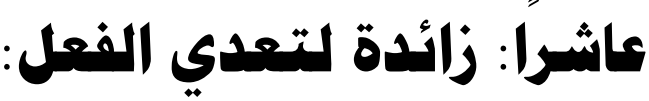

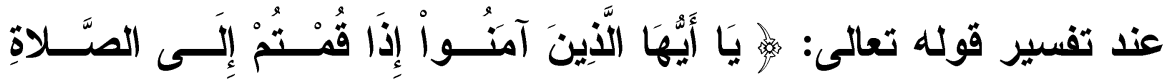

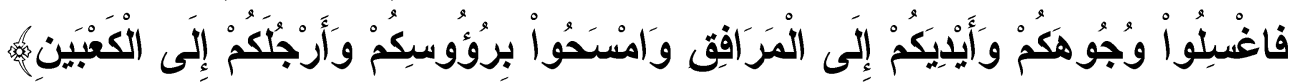
[المائدة: צ]، قال الألوسي:" وامسحوا برعوسكم" قيل: الباء زائدة لتعـدي الفعـل بنفسه، وقيل: للتبعيض، وقد نقل ابن مالك عن أبي علي في التذكرة أنها تجـيء

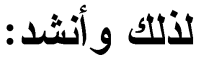

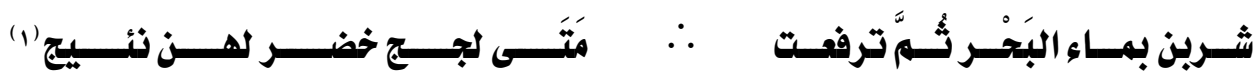
وقال ابن عطية:" و"الباء" في قوله:" برؤوسكم " مؤكدة زائدة عنـــ مـن يرى عموم الرأس، والمغنى عنده: وامسحوا رؤوسكم، وهي للإلزاق المحض عند

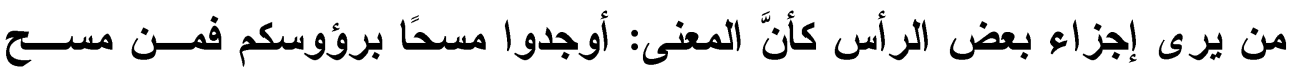

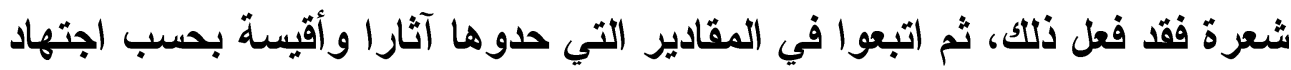
العلماء رحمهم الله" (؟).

و أضاف أبو السعود :"الباء" مزيدة، وقيل للتبعيض فإنه الفارق بين قولكك مسحت المنديل ومسحت بالمنديل، وتحقيقه أنها تدل على تضمين الفعـل معنـى

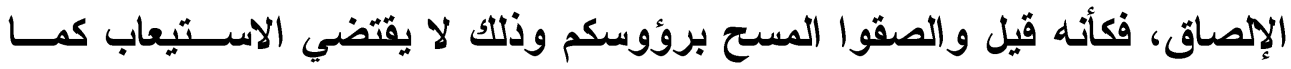

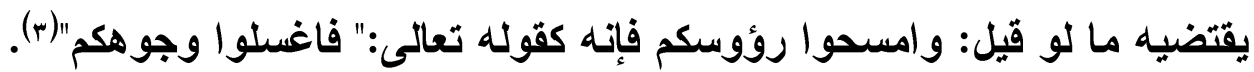

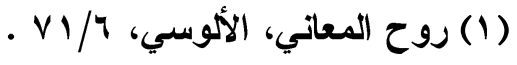

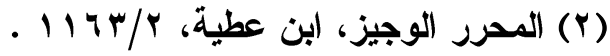

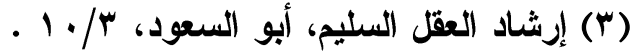




\section{الترقيم الدولم ISSN 2356-9050}

\section{الحادي عشر: الدلالة على لزوم ها بعدها لما قبلها:}

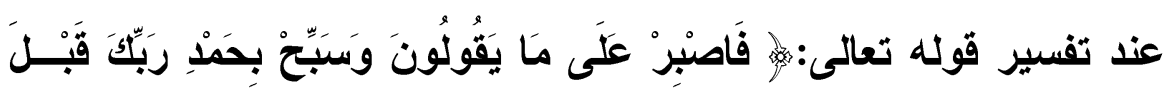

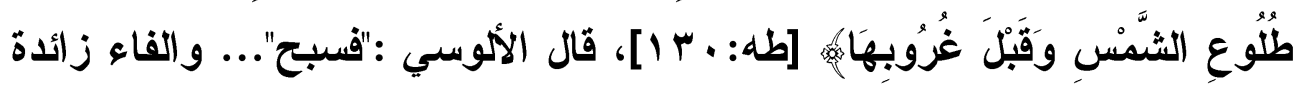

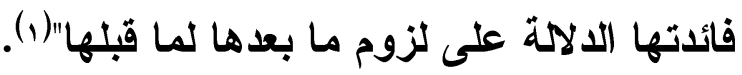



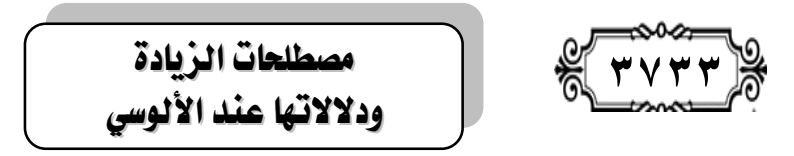

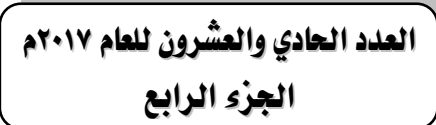

\section{الخاتمة}

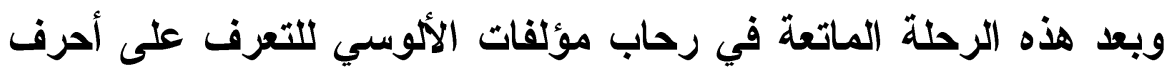

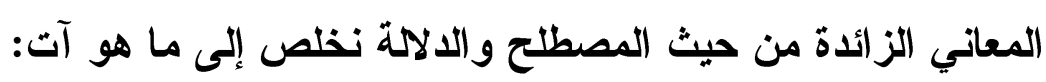

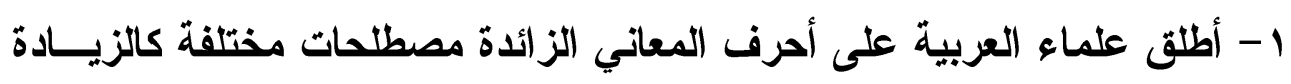

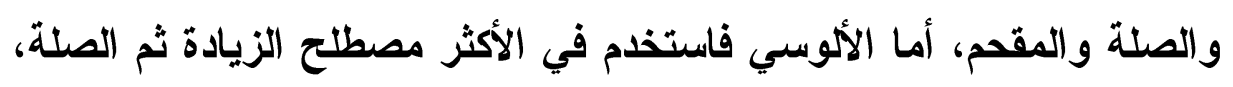
و المقحم -وهو قليل جدَّا- وكان يعيب على من استخدمه، وأضاف مصطلحًا

رابعًا هو "سيف خطيب".

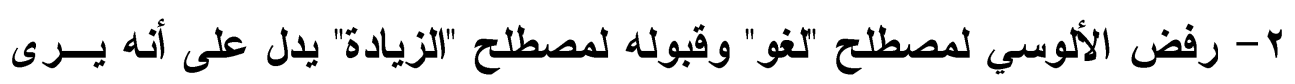

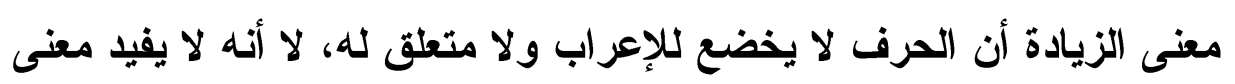

$$
\text { في العبارة. }
$$

r-لم يسبق أحد من أهل اللغة والتفسير الألوسي في استخدام مصــطلح ("ســيف

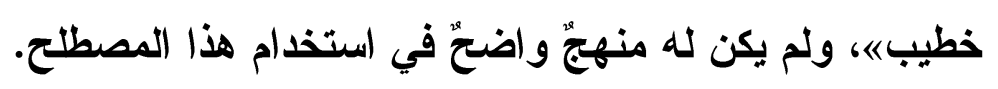

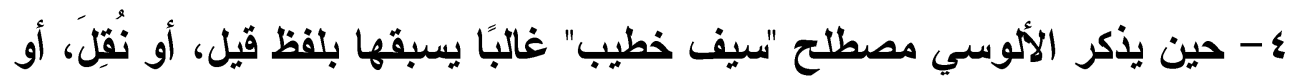

$$
\text { خرَّجه....إلخ. }
$$

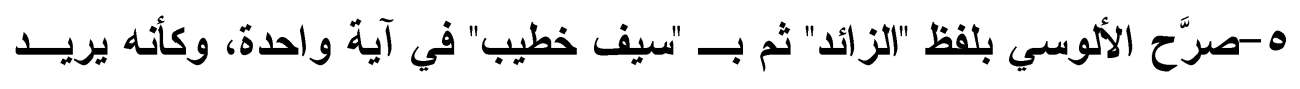

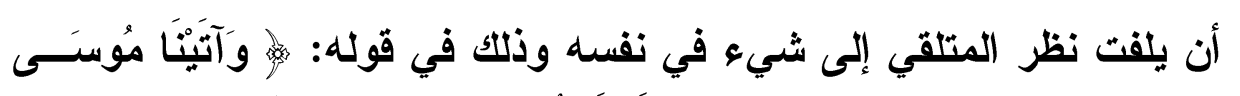

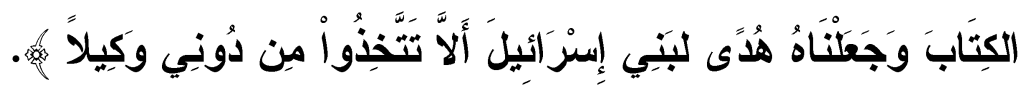

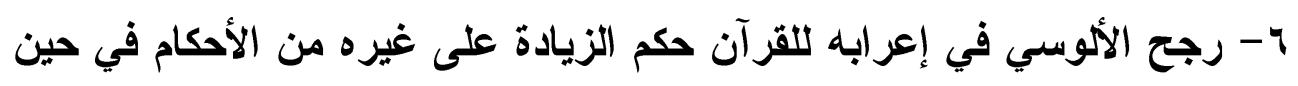
رجح الآراء الأخرى على حكم الزيادة.

V صرّح الألوسي في تفسيره بموقفه من الزائد في القرآ آن الكريم حيث قـــال:"

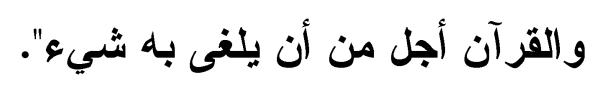

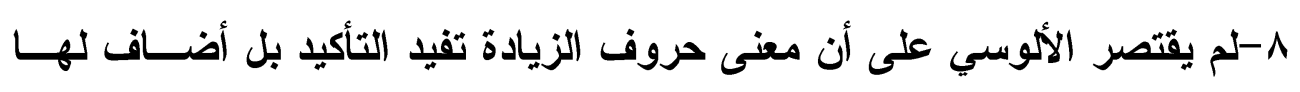
مجموعة من المعاني و الدلات المختلفة. 


\section{الترقيم الدوله \\ ISSN 2356-9050}

\section{المصادر والمراجع}

- الأستراباذي، رضي اللين محمدل بن الحسن.

ا شرح الرضي على الكافية، تحقيق، يوسف حسن عمر ، جامعة قار يــونس -

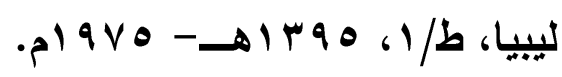
r-شرح الكافية في النحو. ط: دار الكتب العلمية، لبنان - بيروت. - الألوسي، شهاب الدين السيد محمود : r-روح المعاني في تفسير القرآن العظيم والسبع المثاني. ط: دار الفكر - بيروت 1

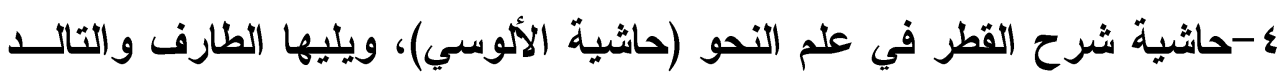

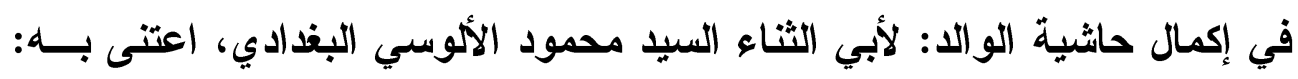

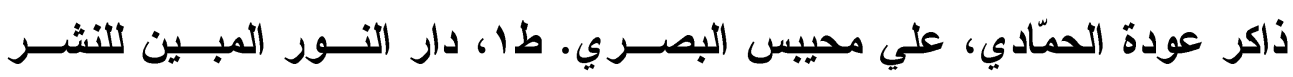

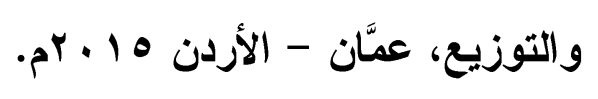

- أبو البركات الأنباري ، كمال الدين عبد الرحمن بن محمد.

ه-الإنصاف في مسائل الخلاف بين النحويين: البصــريين والكــوفيين، المكتبــة

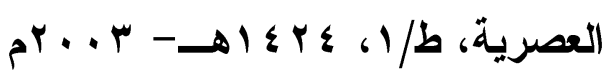

$$
\begin{aligned}
& \text { - البنا، أحمد بن محمد. }
\end{aligned}
$$

צ-إتحاف فضلاء البثر في القراعات الأربعة عثر . ت: شعبان محمد إبــماعيل.

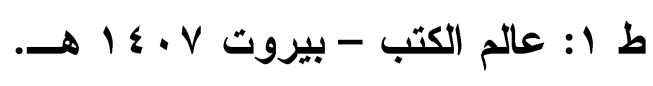

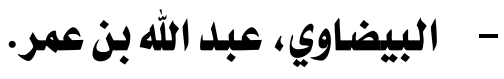

v-أنوار التنزيل وأسرار التأويل. (تفسير البيضاوي) ط: دار الفكر - بيروت. 


\section{مصطاحات الزيادة ودلالاتها عند الألوسي}

Trmo

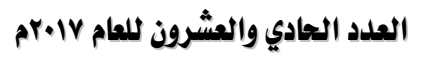

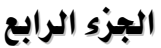

- الجكني، محمد الأمين بن محمد بن المختمار. 1-أضواء البيان في إيضاح القرآن بالقرآن. ت: مكتب البحوث و الار اســات. ط:

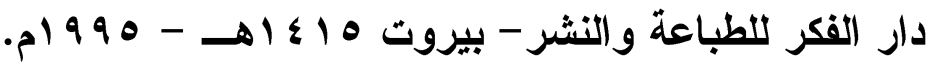
- ابن جني، أبو الثتح عثمان: 9-الخصائص. ت: محمد علي النجار، ط الثانية، دار الهلى - بيروت. • أسر صناعة الإعراب. ت: د. حسن هنــداوي. ط ا، دار القلـم - دمشــق

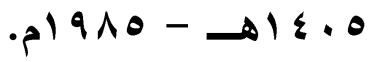
- حاجي خليفة، مصطفى بن عبد الله. 1 ا-كشف الظنون عن أسامي الكتب والقنون. ط: مكتبة المثنى - بيروت.

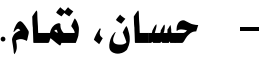

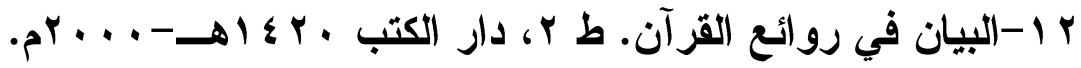
- حويش، عبد القادربن ملا.

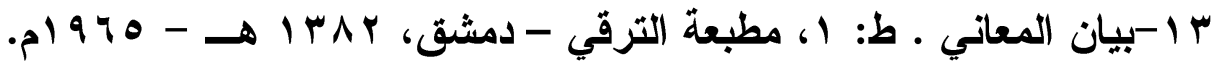
- أبو حيان الأندلسي، محمد بن يوسف: ع ا-البحر المحيط. ط: النصر الحديثة - الرياض.

ه ا-التذييل والتكميل في شرح التسهيل. ت: د. حسن هنداوي. ط: ا، دار كنــوز إثبيليا للنشر والتوزيع. - ابن الخباز، أحمد بن الحسين. 7 أتوجيه اللمع. ت: د. فائز زكي محمد ديــاب. ط: ا، دار الســلام- القــاهرة

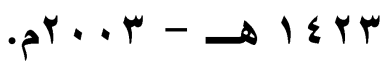

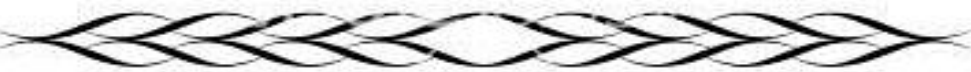




\section{الترقيه الدوله ISSN 2356-9050}

\section{درويش، محيب الدين.}

IV

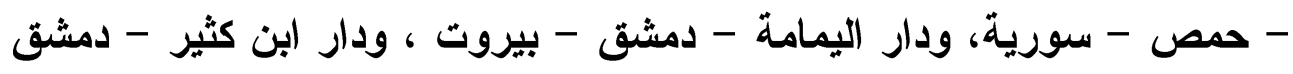

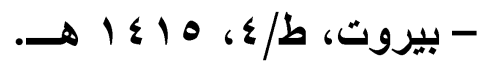

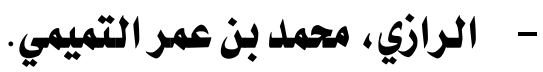

11-التفسير الكبير أو مفاتيح الغيـب. ط: ا، دار الكتـب العلميــة - بيـروت

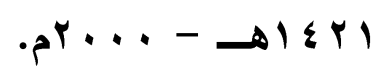
رضا، محمد رشيد. 9 19 - تفسير المنار، الهيئة المصرية العامة، ، 99 ام، د.ط.

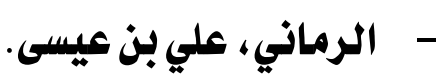
•r-معاني الحروف. ت: د. عبد الفتاح إسماعيل شلبي. ط: ז، دار الثــروق -

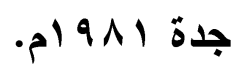

- الزركشي. محمدل بن عبلد اللله بن بهادر. اب-البرهان في علوم القرآن. ث: محمد أبو الفضل إبراهيم. ط: دار المعرفــة،

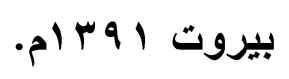
- الزركلي، خير الدين بن محمود بن محمد.

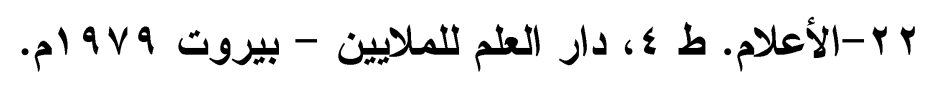
- الزمخشري، محمود بن عمر. بr-الكشاف عن حقائق غو امض التنزيل. ط: مطبعة الريان للتراث. 
مصطلحات الزيادة

ودلالاتها عند الألوسي

- ابز السراج، محمد بن سهل.

ع r-الأصول في النحو. تحقيق د.عبد الحسين الفتلي. طا، الرسالة - بيـروت، $\rightarrow 1 \leqslant \cdot 0$

- أبو سعيد السيرافي : الحسن بن عبد الله بن المرزبان هץ-شرح كتاب سييويه، تحقيق: أحمد حسن مهالي، علي سيد علي، دار الكتب

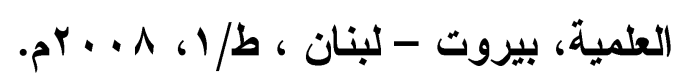
-

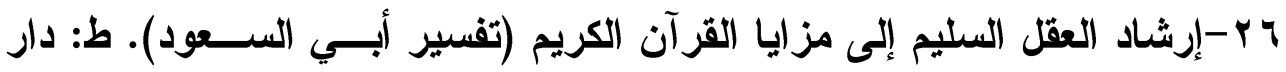

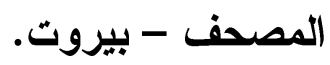

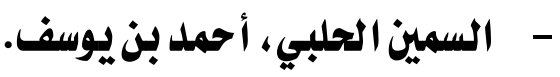
دمثئ TV الار المصون في علوم الكتاب المكنون. ت: د. د. أحمد الخراط، ط: دار القلم -

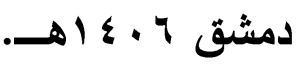

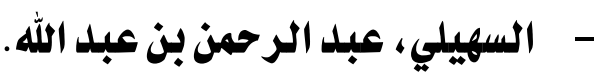

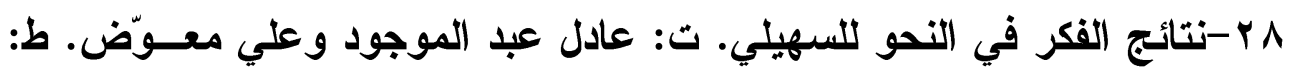

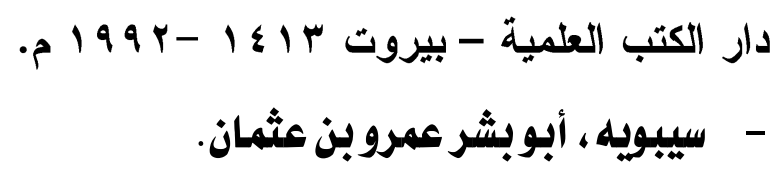

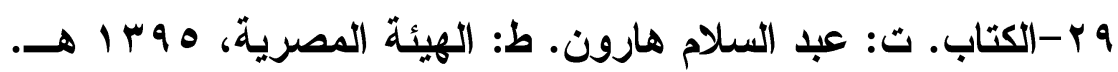

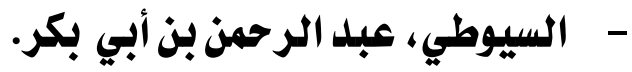

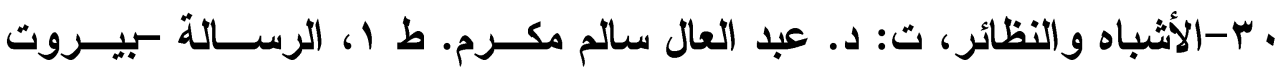
. $1 \leqslant 17$

$$
\text { اب-همع الهوامع. ط دار المعرفة - بيروت. }
$$


- الصافي، محمود بن عبد الرحيه.

r r-الجدول في إعراب القرآن. ط: ع، دار الرشيد، مؤسسة الإيمسـان - دمشـق 11

- ابن عطية، عبل الحق بن غالب. ب ب-المحرر الوجيز في تفسير الكتاب العزيز. ت: الرّحالي الفاروق وعبد الله بن إبراهيم الأنصاري والسيد عبد العال السيد إبراهيم ومحمد الثافعي صادق العناني.

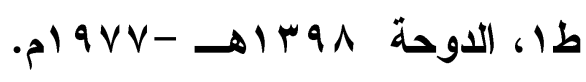
- - العكبري، عبد الله بن الحسين. ع ب-التبيان في إعراب القرآن. ت: علي محمد البجاوي. ط: عيسى البابي الحلبي - مصر -

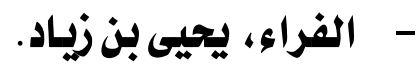
هـ-معاني القرآن. تحقيق أحمد نجاتي، ومحمد النجار. طץ، الهيئة المصـرية، . $) 9 \wedge$. - القرطبي، محمدل بن أحمد.

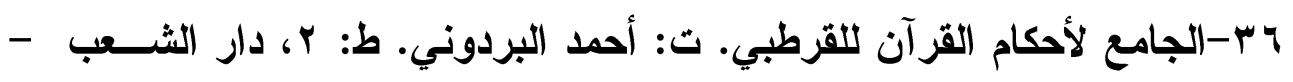

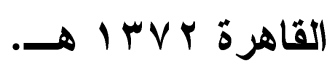
-الثيسي، مكي بن أبي طالب.

Vr-مشكل إعراب القرآن. ت: د. حاتم الضــامن. ط: ب، مؤسســـة الرســالة -

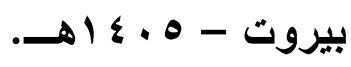




\section{مصطاحات الزيادة ودلالاتها عند الألوسي}

العدد الحادي والعشروز للعام rr.lVم العزي

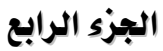

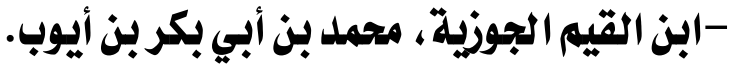
^r-بديع الفوائد. ت: علي بن محمد العمــران، ط: دار عــالم الفوائــــ للنثــر و والتوزيع.

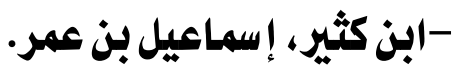
q ب-تفسير القرآن العظيم. ط: دار الفكر - بيروت - 1 ــ اهـ. - - المبرد، أبو العباس محمد بنزيزيل. • ـ -المقتضب. تحقيق محمد عبد الخالق عضيمة. ط وزارة الأوقاف بالقــاهرة، $-11999$ اء -إعراب القرآن. تحقيق خالد العلي. ط ץ، دار المعرفة. r ع - عمدة الكتاب ، تحقيق: سام عبد الوهاب الجابي، دار (بن حـزم - الجفــان

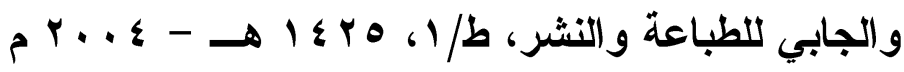
- النسفي، عبد الله بن أحمد. ب ع-مدارك التنزيل وحقائق التأويل (تفسير النسفي).

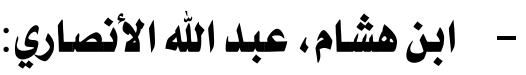

؛ ؛ -أوضح المسالك إلى ألفية ابن مالكك. تحقيق: محمد محيي الدين عبد الحميد.

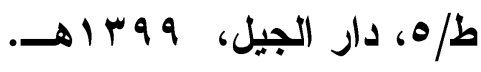

0 ؛ -شرح شذور الأهب في معرفة كلام العرب. تحقيق محمد محيى الدين عبـــ

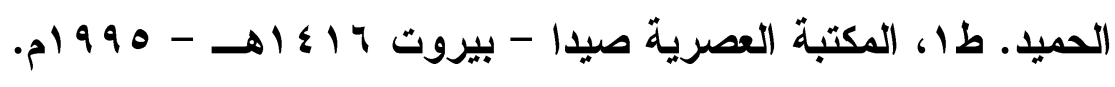

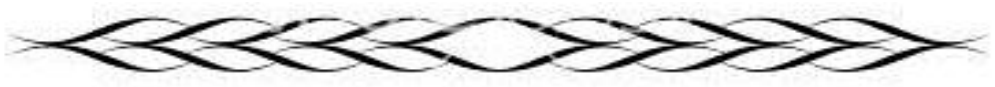




\section{الترقيم الدولم ISSN 2356-9050}

ج ع-شرح قطر الندى ويل الصدى. ت: محمد محيي الاين عبد الحميد، ط: بيروت - 1991

\& V -مغتي اللبيب عن كتب الأعاريب. تحقيق د. مازن المبارك، ومحمد علي حمد الله، طه، دار الفكر - بيزوت. -الهمذاني، حسين بن أبي العز. ^ـ -الفريد في إعراب القرآن المجيد. ت: د. محمد النمــر، ط ا، دار الثقافــة $.1 \leqslant 1 \mid$

- الورده، عبد الأمير محمل.

9 -منهج الأخفش في الدراسة النحوية. ط: ا، مؤسسة الأعلى- بيروت ه و ام . - ابن يعيش ، يعيش بن علي. • • م-شرح المفصل. ط. المنيرية. - يوسف، عبد الكريم محمد.

اه-أسلوب الاستفهام في القرآن الكريم - عرضه و إعرابه. طا، مطبعة الشام،

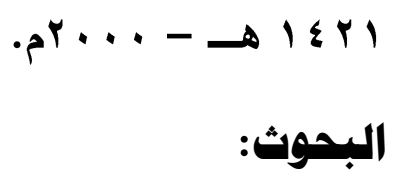
- ناصف، علي النجلدي. ا-بحث "هل في القرآن الكريم من أحرف الزيادة". 


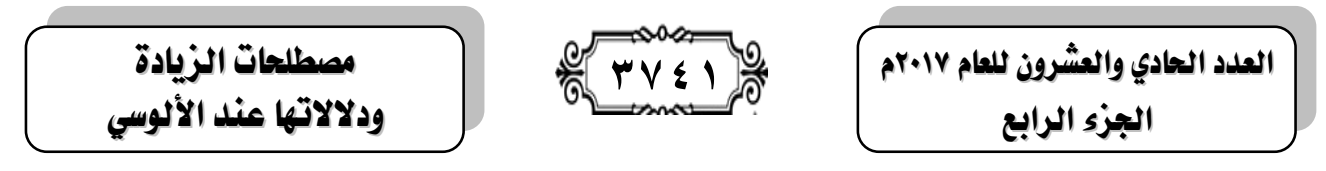

فهرس الموضوعات

\begin{tabular}{|c|c|c|}
\hline لمفمثم & الموضوع & $p$ \\
\hline ranl & |الذص & 1 \\
\hline rMar & التمهيد & r \\
\hline rMAN & وحاشية القطر: & $r$ \\
\hline rMAN & ا - هصطلح الزائد: & $\varepsilon$ \\
\hline ryar & r- هصطلح الصلة & 0 \\
\hline r790 & r- هصطلح المقم: & 1 \\
\hline ryav & ع- هصطلح سيف خطيب & $v$ \\
\hline ry.. & هواضع ورود "سيف خطيب” عند الألوسي: & $\wedge$ \\
\hline$r v+1$ & أولاً: في تفسيره روح المعاني: & 9 \\
\hline rriq & ثانياً: حاشية الألوسي على شرح القطر: & 1. \\
\hline rrri & دلالة حروف الريادة عند الألوسي في "روح المعاني": & 11 \\
\hline rurs & أولاً: إفادة السببية: & ir \\
\hline ruro & ثانياً: التوكيد: & ir \\
\hline rury & 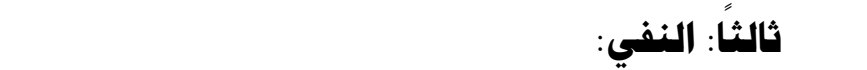 & $1 \xi$ \\
\hline rury & رابعاً: التنبيه: & 10 \\
\hline rrra & خامساً: المبالغة: & 17 \\
\hline
\end{tabular}

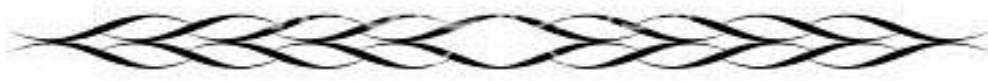




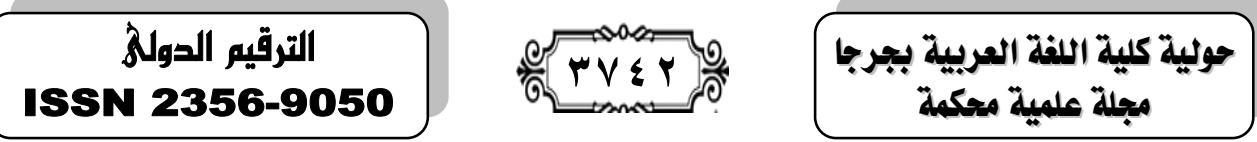

\begin{tabular}{|c|c|c|}
\hline رقمثم & الموضوع & $p$ \\
\hline rrra & سادساً: أن تكون بمعنى الحال: & iv \\
\hline rrra & سابعاً: الدلالة على همنى الأهر: & IA \\
\hline rrra & ثاهنًا: بمعنى قد: & 19 \\
\hline rur. & تاسعاً: هتضمنة همعنى الشرط: & r. \\
\hline rrri & عاشرا: زائدة لتعدي الفعل: & r \\
\hline rurr & الحادي عشر: الدلالة على للزوم ها بعدها لما قبلها: & rr \\
\hline ryrr & 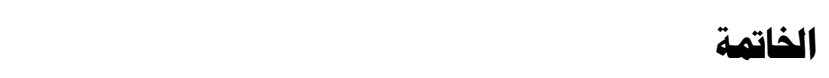 & rr \\
\hline rurs & الصادر والمراجع & rs \\
\hline rysi & فهرس الموضوعات & ro \\
\hline
\end{tabular}

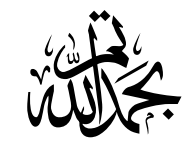

